\title{
AN INVESTIGATION OF THE USE OF THE MOISTURE - TENSION METHOD FOR DETERMINATION OF LIQUID AND PLASTIC LIMIT VALUES OF SOIL
}

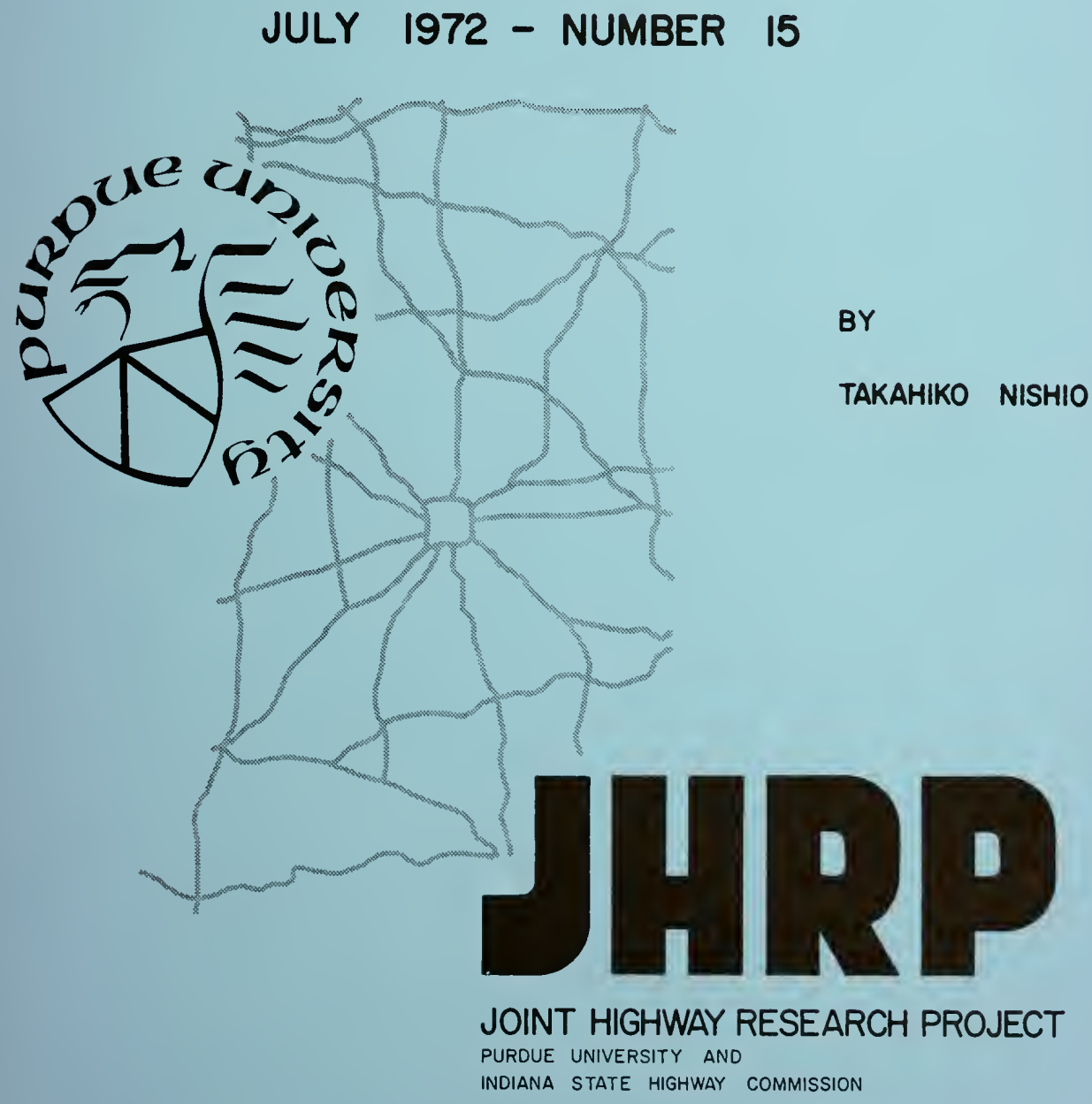


Final Report

AN INVESTIGATION OF THE USE OF THE MOISTURE-TENSION METHOD FOR DETERMINATION OF LIQUID AND PLASTIC

\section{LIMIT VALUES OF SOIL}

TO: J.F. Melaughlin, Director

Joint Highway Research Project

FROM: H. L. Michael, Associate Director Joint Highway Research Project
July 26, 1972

Project: C-36-5I

File: $6-6-9$

Attached is a Final Report entitled "An Investigation of the Use of the Moisture Tension Method for Determination of Liquid and Plastic Limit Values of Soil", by Mr. Takahiko Nishio. This work was conducted under the supervision of Professor E. J. Yoder and Mr. Eugene R. Russell of our staff.

The purpose of the study was to investigate the feasibility of using moisture tension techniques for estimating the liquid and plastic limits of soils. If the moisture tension method can be developed so that it will give reliable data it would result in considerable savings in time and money for performing these routine tests.

The results indicate that, using the two moisture-tension devices in our laboratory, the liquid and plastic limits can be predicted with some certainty by this method. Regression equations are presented which relate the consistency limits to moisture content determined using moisture tension techniques.

However, it is believed that additional work should be done to study the method further. The moisture tension method for estimating plasticity is perhaps at the same stage in development as nuclear moisture-density measurement was some 10 years ago. It is our belief that the method can be developed to where it can be used on a production basis by the Indiana State Highway

Commission.

The report is submitted for acceptance as fulfillment of the objectives of this Study.

HLM:ms

cc: W. L. Dolch

R. L. Eskew

W. H. Goetz

W. L. Grecco

M. J. Gutzwiller

G. K. Hallock

Respectfully submitted,

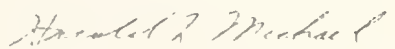

Harold L. Michael, Associate Director

R. H. Harrell

M. L. Hayes

C. W. Love 11

G. W. Marks

R. D. Miles

J. W. Miller
C. F. Scholer

M. B. Scott

J. A. Spooner

N. W. Steinkamp

H. R. J. Walsh

E. J. Yoder 
Final Report

AN INVESTIGATION OF THE USE OF THE MOISTURE-TENSION METHOD FOR DETERMINATION OF LIQUID AND PLASTIC LIMIT VALUES OF SOIL

\author{
by \\ Takahiko Nishio \\ Graduate Assistant in Research \\ Joint Highway Research Project \\ Project No.: C-36-5I \\ File: $\quad 6-6-9$ \\ Conducted By \\ Joint Highway Research Project \\ Engineering Experiment Station \\ Purdue University \\ In Cooperation With \\ Indiana State Highway Commission
}

Purdue University

Lafayette, Indiana

July 26, 1972 
ACKNOWLEDGMENTS

The author wishes to express his sincere appreciation to his major advisor, Professor E. J. Yoder, for his advice, guidance and understanding during the course of this investigation and the preparation of this thesis; to Professor V. L. Anderson for his advice on statistical procedures and review of the manuscript.

Appreciation is also extended to Mr. E. R. Russell for his advice and review of the manuscript; to Miss K. M. DeWald for her comments on statistical analysis for this research; and to $\mathrm{Mr}$. F. Makdisi-Ilyas for his review of the manuscript.

The financial support of this research from the Joint Highway Research Profect and Purdue University is duly acknowledged.

The author would also like to express his thanks to Mrs. Linda Muench for typing of the manuscript. 
Digitized by the Internet Archive in 2011 with funding from

LYRASIS members and Sloan Foundation; Indiana Department of Transportation 
TABLE OF CONTENTS

Page

LIST OF TABLES. . . . . . . . . . . . . . . . . . . . v

LIST OF FIGURES . . . . . . . . . . . . . . . . . . . víi

ABSTRACT. . . . . . . . . . . . . . . . . . . . . . ix

INTRODUCTION. . . . . . . . . . . . . . . . . . . . . . I

PURPOSE OF THE STUDY. . . . . . . . . . . . . . . . . . . 3

REVIEW OF LITERATURE. . . . . . . . . . . . . . . . . . . . . 4

Research on the Atterberg Limits. . . . . . . . . . . . . . 4

Development of Molsture Tension Method. . . . . . . . . . . . . 5

THE APPARATUS AND MATERIAL USED . . . . . . . . . . . . . . . . . 10

Moisture Tension Method Equipment . . . . . . . . . . . . . . I0

Extractor and Ceremic Plate Cells . . . . . . . . . . . . . . . . . . . . . . . .

Pressure Regulator and Measurement. . . . . . . . . . . . . . . . 12

Other Tools for the Pressure Test . . . . . . . . . . . . . . 12

Soils and Soil Mixtures . . . . . . . . . . . . . . . . . . . .

PROCEDURES AND TESTS CONDUCTED. . . . . . . . . . . . . . . . . . . 21

Standard Test for Consistency Limits of Soils . . . . . . . . . . . .2l

Molsture Tension Test . . . . . . . . . . . . . . . . . 2l

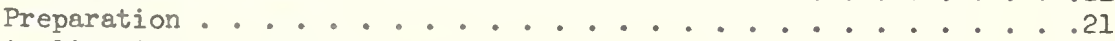

Application of Pressure . . . . . . . . . . . . . . . . . . 22

Tests for Moisture Tension Curves . . . . . . . . . . . . . . . 22

Tests for Time Factor Study . . . . . . . . . . . . . . . . . 23

Tests for Prediction Curves of Atterberg Limits . . . . . . . . . 24

RESULTS . . . . . . . . . . . . . . . . . . . . . . 25

Consistency Limits by the Standard Method . . . . . . . . . . . .25

Prediction of the Plesticity of Soils by the Moisture Tension

Method. . . . . . . . . . . . . . . . . . . . . . 33

All Random Combinations . . . . . . . . . . . . . . . . 35

Random Pull . . . . . . . . . . . . . . . . . . . . . . . . . . . . . . . . . .

Analysis of the Artificially Prepared Solls . . . . . . . . . . 37

Interpretation of the Regression Analysis Results . . . . . . . . .37

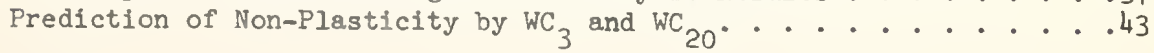


Some Characteristics of the Moisture Tension Method . . . . . . . .43

Shape of Moisture Tension Curves. . . . . . . . . . . . . . 43

The Relationship Between Soll Composition and Moisture Tension. . .45

Factors Affecting the Moisture Tension Method . . . . . . . . . . .50

Equipment and Ceramic Plate . . . . . . . . . . . . . . 50

Time Factor Study . . . . . . . . . . . . . . . . . . . . . 52

SUMMARY AND RECOMMENDATIONS . . . . . . . . . . . . . . . . 56

BIBLIOGRAPHY. . . . . . . . . . . . . . . . . . . . . . . .

APPENDICES

Appendix A: Test Data. . . . . . . . . . . . . . . . 60

Appendix B: Tests for Operator Effect. . . . . . . . . . . . 79

Appendix C: Input Data for Regression Analysis . . . . . . . . .82

Appendix D: Coefficient of Variation .............. . . . 87

Appendix E: Molsture Tension Curves. . . . . . . . . . . . . 90

Appendix F: Relationships Between Moisture Tension and Soil

Composition . . . . . . . . . . . . . . . . . 99 
LIST OF TABLES

Table

Page

1. Soil Moisture Tension Giving Moisture Content Approximately the Liquid Limits . . . . . . . . . . . . 7

2. Sieve Analysis of the Natural Solls . . . . . . . . . . . 15

3. Textural Classification of the Natural Soils. . . . . . . . 16

4. Textural Classification of the Artificially Prepared Soils. . . I7

5. Number of Tests Conducted on Natural Soils. . . . . . . . . 26

6. Liquid Limit Values by Several Operators. . . . . . . . . . 27

7. Plastic Limit Values by Several Operators . . . . . . . . . 29

8. Tests for Operator Effect (LL). . . . . . . . . . . . . 31

9. Tests for Operator Effect (PL). . . . . . . . . . . . 31

10. Two-way ANOVA of $\mathrm{WC}_{3}$ and $\mathrm{WC}_{20}$ by Three Operators....... . . 34

11. Homogeneity of Variance Calculated for the Data Shown in Table C-l by the Foster-Burr Test . . . . . . . . . . 36

12. Prediction Equations for Consistency Limits (natural soils) . . 38

13. Prediction Equations for Consistency Limits (artificially prepared soils) . . . . . . . . . . . . . . . 39

14. Prediction Equations for Consistency Limits (Utah Soils from Sultan). . . . . . . . . . . . . . . . 40

Appendix

Table

A-1 Summary of Liquid Limit Values. . . . . . . . . . . . 60

A-2 Summary of Plastic Limit Values . . . . . . . . . . .63

A-3 Summary of Test Results for the Artificially Prepared Soils . .66

A-4 Water Content by Moisture Tension Test ( $\mathrm{WC}_{3}$, Operator H). . . .67

A-5 Water Content by Moisture Tension Test ( $\mathrm{WC}_{20}$, Operator H) . . .68 
Appendix

Table

Page

A-6 Water Content by Moisture Tension Test (WC 3 , Operator I). . . 69

A-7 Water Content by Moisture Tension Test ( $\mathrm{WC}_{20}$, Operator I) . . .70

A-8 Water Content by Moisture Tension Test $\left(\mathrm{WC}_{3}\right.$, Operator J). . . .71

A-9 Water Content by Moisture Tension Test (WC ${ }_{20}$, Operator J) . . .72

A-10 Effect of Plate on Test Results . . . . . . . . . . . . .73

A-Il Effect of Time and Pressure on Water Content. . . . . . . . .74

B-I Two-way ANOVA for LL. . . . . . . . . . . . . . . . . . . . .

B-2 Two-way ANOVA for PL. . . . . . . . . . . . . . . 80

B-3 Tests Between Two Operators, LL . . . . . . . . . . . . 81

B-4 Tests Between Two Operators, PL . . . . . . . . . . . 81

C-1 Input Data for the all Random Combination Analysis. . . . . . .82

C-2 Input Data for the Random Pull Analysis . . . . . . . . . .86

D-1 Coefficient of Variation, $\frac{\mathrm{S}}{\overline{\mathrm{D}}} \times 100$ (\%) (LL, PL, $\mathrm{WC}_{3}, \mathrm{WC}_{20}$ ) . . .87

D-2 Coefficient of Variation, $\frac{\mathrm{S}}{\bar{D}} \times 100(\%)$ (Predicted LI Values) . .88

D-3 Coefficient of Variation, $\frac{\bar{S}}{\bar{D}} \times 100(\%)$ (Predicted PL Values) . .89

F-1 Soll Composition for the Passing $\$ 40$ Portion of the

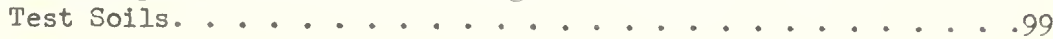


LIST OF FIGURES

Figure

Page

1. The Extractor and the Ceramic Plate Cell ...........11

2. Set up of Equipment Showing Two Extractors . . . . . . . .13

3. Moisture Tension Test Equipment. . . . . . . . . . .14

4. Textural Classification of the Natural Soils . . . . . . . . 19

5. Textural Classification of the Artificially Prepared Solls . .20

6. Suggested Boundary Lines - Non Plastic Soils . . . . . . . . .44

7. Relationship Between $W_{3}$ and $W_{20}$ (natural soils)...... . .47

8. Relationship Between $W_{3}$ and $W C_{20}$ (artificially parepared

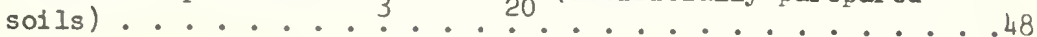

9. Relationship Between $\mathrm{WC}_{3}$ and $\mathrm{WC}_{20}$.................... 49

10. Water Content Variation Between Plates . . . . . . . . . 51

11. The Changes of Water Content Deviation by Pressures. . . . . 51

12. Effect of Time and Pressure on Molsture Content, Soil No. 2. .53

13. Effect of Time and Pressure on Moisture Content, So11 No. 3. .53

14. Effect of Time and Pressure on Moisture Content, Soil No. 5. .54

15. Effect of Time and Pressure on Moisture Content, Soil No. 6. .54

16. Effect of Pressure and Loading Time on Equilibrium Moisture Content . . . . . . . . . . . . . . . 55

Appendix

Figure

A-1 Effect of Percent Soll in the Mix on Test Values for the Artificially Prepared Soils. . . . . . . . . . .76

A-2 Effect of Percent Soll in the Mix on Test Values for the Artificially Prepared Solls. . . . . . . . . . . .77 
Appendix

Figure

A-3 Effect of Percent Soil in the Mix on Test Values for the Artificially Prepared Soils. . . . . . . . . . . .78

E-1 Moisture Tension Curves Developed Using Two Procedures for Applying Pressure. . . . . . . . . . . . . . 90

E-2 Moisture Tension Curves Developed Using Two Procedures for Applying Pressure. . . . . . . . . . . . . . .91

E-3 Moisture Tension Curves for Three Clays. . . . . . . . . .92

E-4 Moisture Tension Curves for Two Clay Loams (1) . . . . . . .93

E-5 Moisture Tension Curves for Two Clay Loams (2) . . . . . . 94

E-6 Moisture Tension Curves for Two Sandy Clay Loams (1) . . . .95

E-7 Moisture Tension Curves for Three Sandy Clay Loams (2) . . . .96

E-8 Moisture Tension Curve for Loam. . . . . . . . . . . . .97

E-9 Moisture Tension Curve for Sandy Loam. . . . . . . . . . .97

E-10 Moisture Tension Curve for Silty Clay Loam . . . . . . . .98

F-1 Relationship Between the Portion $\# 40$ 0.05mm and $W_{3^{\circ}}{ }^{*} . .101$

F-2 Relationship Between the Portion (-\#4000.05m and $-0.005 \mathrm{~mm}$ ) and $\mathrm{WC}_{3}$................... 102

F-3 Relationship Between the Portion (2mm 0.05mm) and $\mathrm{WC}_{3}{ }^{\circ} . .103$

F-4 Relationship Between the Portion $(-0.005 \mathrm{~mm})$ and $W_{20}$. . . 104

F-5 Relationship Between the Portion (-\#40 0.05m and -0.005mm)

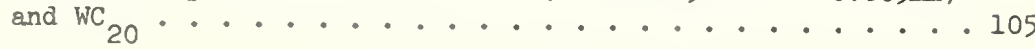

F-6 Relationship Between the Portion $(-0.05 \mathrm{~mm} 0.005 \mathrm{~mm})$ and $\mathrm{WC}_{20} \cdot 106$

F-7 Relationship Between the Portion (-\#40 0.05mm) and

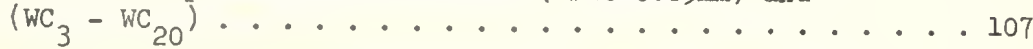

F-8 Relationship Between the Portion $(-0.05 \mathrm{~mm} \sim 0.005 \mathrm{~mm}$ and

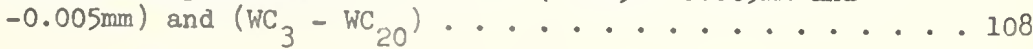


ABSTRACT

Nishio, Takahiko. M.S.C.E., Purdue University, June 1972. An Investigation of the Use of the Molsture-Tension Method for Determination of Liquid and Plastic Iimit Values of Soil. Major Professor: E. J. Yoder.

The purpose of this research was to study the relationship between moisture content as determined by molsture tension techniques and the consistency limits for Indiana soils.

Twenty-eight soils obtained from different locations of the state of Indiana and twenty-nine artificially prepared soils (varying gradations) from the same natural soils were studied. The ceramic plate apparatus was used for the moisture tension method. The effect of using different operators to run both the standard tests for liquid and plastic limit and the moisture tension tests was evaluated.

It was found that either $\left(w_{20}\right)^{2},\left(w C_{3}\right)^{2}$ or $\left(W C_{3}\right)\left(w C_{20}\right)$, where $W_{3}$ is moisture content at $3 \mathrm{psi}$ in the molsture tension device and ${ }^{W C} C_{20}$ is moisture content at 20 psi correlated well with the liquid and plastic limits and the plasticity index of the soils. The correlation was established for all the soils used regardless of their textural classification. The results of the study suggest the possibility of using moisture tension to estimate the grain size distribution of soils. 


\section{INTRODUCTION}

Since Albert Atterberg (3) studied the arbitrary identification limits called the "liquid" and "plestic" limits of a soll, a great volume of information has been collected correlating the limits with other soil properties. Some researchers claim that the consistency limits are too empirical and there is no rational basis for them. It is also believed by some that the results are too sensitive subject to variation beceuse of the standard device and because of operator technique.

Recently, however, there have been attempts made by researchers and engineers in this field, to develop new devices and techniques that can be substituted for the present standard method. Hence, it becomes necessary to correlate results by the new methods with those obtained by the standard method, since the results of the standard method have been widely used for such a long period of time.

The moisture tension method has recently been developed and the results used to predict the liquid and plastic limits of a soil $(12,13,14)$. All investigators to date have emphasized that further research is needed. They report some advantages of the new method as follows:

1. It appears possible for a ingle operator to determine the liquid limit of several hundred soils in a few days.

2. Minimum attention to technique is required and no prior training or experience is necessary to determine values by the method. 
3. The results by this method show a higher degree of reproducibility and consistency.

However, all correlations have depended upon grouping the samples into different soil textural classifications. This appears to be one of the shortcomings of the new method, because a partial hydrometer test is necessary to classify the soils. The hydrometer test is time consuming and difficult to run. Another shortcoming is that different pressure intensities are required for various soils depending upon the soll's textural classification. Moreover, very few tests have been made on non-plastic materials. This may be fatal in use of the moisture tension method, since we have a risk of estimating a certain value as a plastic limit of a soil even if it does not actually have a plastic limit in the standard test. 
PURPOSE OF THE STUDY

This research project was undertaken to evaluate the feasibility and reliability of using the moisture tension method for predicting the liquid and plastic limits. The specified objectives of this study are as follows:

1. To verify the relationship between the consistency limits and the moisture tension values for various types of soils from the state of Indiana.

2. To establish the above relationship with less restrictions of test technique and regardless of soil textural classiPication.

3. To investigate equipment and operator variability and reliability of this method.

4. To find if a relationship exists between the soil composition and soll moisture tension values. 
REVIEW OF LITERATURE

\section{Research on the Atterberg Limits}

The concept of soil plasticity and a method to determine it were first suggested by Albert Atterberg in 1911 (3). Atterberg established the "roll out limit" of a clay; the roll out limit is the moisture content at which the clay paste cannot be rolled into threads. Also, he established the "flow limit" which is the moisture content at which two small portions of cley, lying in a dish, will no longer flow together with vigorous blows of the dish. To Atterberg, plasticity meant "capable of being shaped".

Procedures for determining the plasticity of soil have been greatly refined over the past sixty years. Most researchers have spent major efforts on the improvement of the device and the methods for determining the flow limit. As for roll out limit, the only major improvement has been the specific provision of the diameter of threads $\left(1 / 8^{\prime \prime}\right)$. The flow limit suggested by Atterberg is now designated as the liquid limit and the roll out limit is known as the plastic limit. These test methods and devices are now specified in ASTM Method D423-61T (1) and D424-59 (2) respectively.

Terzaghi (16) and Casagrande (5) emphasized the necessity for establishing a clear definition for the properties studied by Atterberg. They also raised questions relative to what the test results mean and what factors determine their results. It is known 
that even the present test methods as specified in the ASTM are very sensitive to operator technique.

Dawson (6) studied the reliability of liquid limit test results. According to his study, the overall variation in the results ranged from $\pm 5 \%$ to $\pm 10 \%$; he concluded that the liquid limit test (ASTM Method D423-59'T) was questionable and needed further study.

Several questions about the concepts belleved and the procedure for determining plasticity of a soil remain unanswered. However, the Atterberg limits have become one of the most important properties of soils and now are widely used. Many studies have been made linking these limits with other properties of soils. Most recent research in the area of the liquid and plastic limits has been directed at making changes in the present devices and methods.

\section{Derelopment of Moisture Tension Method}

Richards $(8,9,1 Q, 11)$ developed a moisture tension apparatus to measure the capillary potential of soils in 1928. Baver (4) presented a comprehensive explanation of the mechanics of the soil-moisture system. Russell and Mickle (13) summarized Baver's concepts as follows:

"Capillary water is defined as the water which is held by surface forces as a continuous film around the particles and in the capillary spaces. Capillary potential defined as the work required to pull a unit mass of water away from a. unit mass of a soll. Thus, when a pressure difference (suction or pressure) is required to extract water from soil, the amount of water in the soil is a function of the energy with which the water is held. Also, the energy required to remove water is a continuous function of the moisture content; i.e., a given energy will remove a given amount of water and come to equilibrium. When the equilibrium condition of the soil has been reached, the soil has a potential at that point equivalent to the suction (or pressure) applied." 
The application of the moisture tension test for determining the consistency limits of soils was investigated by Rollins and Davidson (12). They found that moisture content at a specific moisture tension corresponded to the consistency limits of a soil. According to their study, different moisture tension values were evaluated to estimate the consistency limits of solls depending upon the textural classification of the soil. This approach seems reasonable since the size of the soil particles is one of the major factors that has a large effect on moisture tension values.

Sultan (14) and Russell and Mickle (13) continued the studies of Rollins and Davidson. Their procedures for estimating the consistency limits of soils were also based upon soil textural classification.

Sultan used fifty five Utah soils which were classified into five groups of sand, sandy loam, silty loam, loam and silty clay loam. He reported that the liquid limits of these soils could be estimated by the moisture tension method by applying specific pressures to each soil type.

Russell and Mickle (13) conducted their researches on Iowa soils. Basically the same techniques and procedures were used as those adapted by the previous two researchers. The results of RusselI and Mickle are shown in Table 1 along with the results of Sultan and Rollins and Davidson. 
Table 1. Soil Moisture Tensions Giving Moisture Content Approximately the Liquid Limits

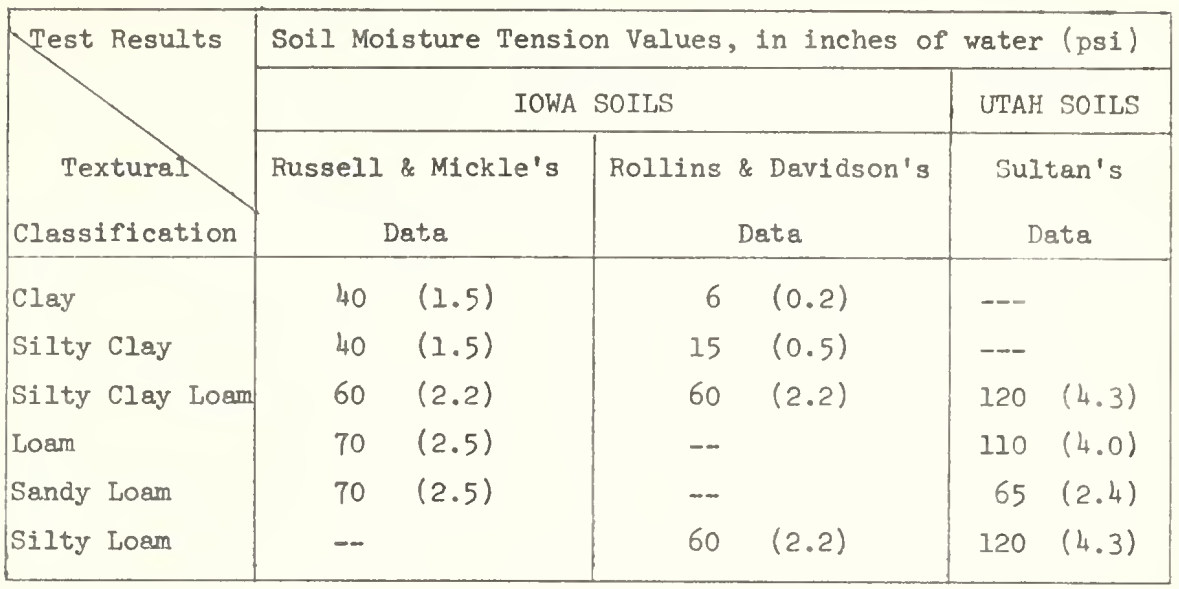

It can be concluded from the above researchers that:

1. If the textural classification of $280 i 1$ is known, its liquid limit can be estimated by sssuming it equal to the moisture content obtained at a certain soil molsture tension.

2. The moisture tension method can be used to estimate the liquid limits of solls with less variation due to operator technique than by the ASTM standard method.

3. The quality of the results and the speed of making determinations make the moisture tension method a valuable substitute for liquid limit devices.

However, Sultan (15) compared the results of the three studies. He concluded that the usage of textural classification, or gradation, of the material as the governing factor in selecting the moisture tension values at which to determine the liquid limit did not constitute a conclusive criterion at the current stage of knowledge. As for plastic limits, an insufficient number of tests were conducted to warrant any conclusions in these three research projects. 
It can be concluded that there appears to be a good relationship between moisture content determined by moisture tension and the liquid limits of soils and that this method might offer a substitute for the standard consistency tests.

Uppal (17) studied the application of the moisture tension method for evaluating the plastic limit. He concluded that, for soils compacted to a bulk density of $1.6 \mathrm{~g} / \mathrm{cm}^{3}$, the plastic limit corresponded to the moisture content at pF $0.5(3.16 \mathrm{~cm}$ of water height) by the wetting method or $\mathrm{pF} 1.5(31.6 \mathrm{~cm}$ of water height) by the drying method. The wetting method is one for which the soil mass is allowed to absorb moisture under a certain pressure and drying method is the one whereby a saturated soil is subjected to a certain suction until it attains equilibrium.

If the air voids can be fixed by controlling the dry bulk density of the soil mass then according to Uppal (17) the plastic limit would only be affected by the amount of solid and liquid in the soil mass. He suggested that a dry bulk density of $1.6 \mathrm{~g} / \mathrm{cm}^{3}$ would give the best results.

The idea that controlling the dry bulk density as an initial condition is interesting. However such a provision of an initial condition makes the test more difficult to perform.

Another study was conducted by Livneh ( 7 ). He concluded that in the range of 2 to $4.2 \mathrm{pF}$ (approximately $1.4 \mathrm{psi}$ and $230 \mathrm{psi}$ respectively), a linear correlation was found between the logarithm of moisture content ( $\log W$ ) of a soil and the corresponding suction value ( $p F)$. Another Iinear correlation was found between log PI of a soil and the corresponding suction value $(p F)$. The main advantage of his method is 
that both plastic limit and plasticity index can be estimated by using a given intensity of pressure. However his method also depended upon soil classification. 
THE APPARATUS AND MATERIAL USED

\section{Moisture Tension Method Equipment}

Extractor and Ceramic Plate Cells

The extractor and the ceramic plate cells are the main apparatus used for the pressure tests of molsture extraction from soils (see Figure 1).

Soil samples are placed on the surface of the ceramic plates and these plates are mounted in the extractor. When pressure is applied in the extractor, excess water from the soil samples is forced out of the extractor through the ceramic plate cells and the outflow tubes.

The extractor has three outlet ports spaced down the wall of the vessel. Each output port takes the outflow from one ceramic plate. A maximum of three ceramic plates can be used in the extractor. Two other ports were used, one for applying pressure to the extractor and the other for measuring this applied pressure by means of a manometer. The outflow tubes from the ceramic plates are connected with the outlet ports on the wall of the extractor to remove the excess water out of the extractor.

Each ceramic plate cell consists of a 1 bar ceramic plate approximately $101 / 4 "$ in diameter which is sealed on one side by a thin neoprene diaphragm. An internal screen keeps the diaphragm from comIng into close contact with the plate and provides a passage for flow of water. An outlet stem running through the ceramic plate connects this passage to the outflow assembly. 


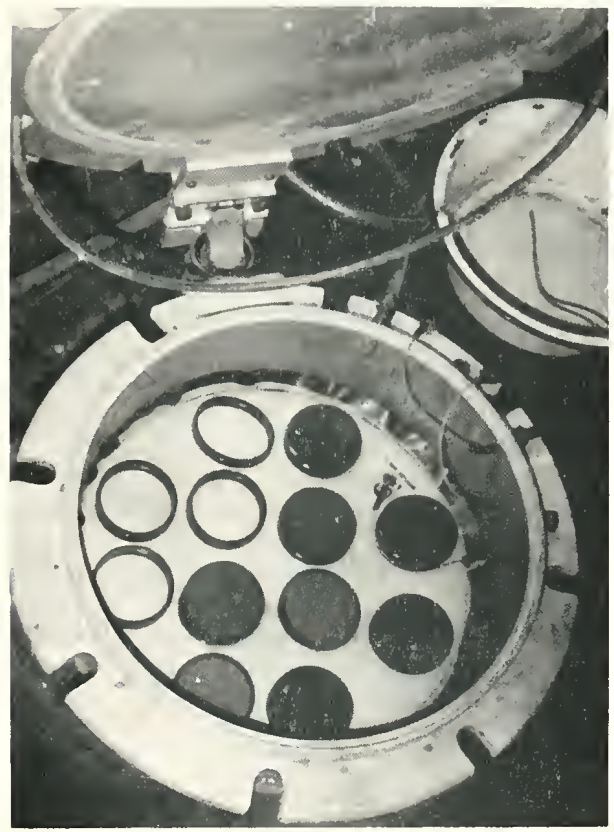

FIGURE 1. THE EXTRACTOR AND THE CERAMIC PLATE CELL 
The ceramic plate cells used in this research are designated "l bar ceramic plate cells". These plates are capable of measurement within a 0 to 1 bar pressure range. A maximum of twelve soil samples can be placed on each plate. Figure 2 shows two extractors as used in this research.

\section{Pressure Regulator and Measurement}

Figure 3 shows in diagram form the laboratory set up and illustrates the various operating parts. The inlet air pressure is adjusted to the required intensity by two regulators. One of the regulators is for high pressure and the other is for low pressure. In this research, the range of the pressure applied was 0.4 psi to about $50 \mathrm{psi}$.

The pressure was measured using two procedures, one was by a test gauge mounted in the regulator system and the other was by a mercury manometer. The manometer was used for low pressure tests up to $10 \mathrm{psi}$; it was connected directly to the extractor.

\section{Other Tools for the Pressure Test}

Rubber rings $1 / 2^{\prime \prime}$ high and $2^{\prime \prime}$ in diameter were used for retaining the soil samples on the ceramic plate as illustrated in Figure 1. Glass jars 2" diameter and 6" high were used for saturating soil samples.

\section{Soils and Soil Mixtures}

Grain size data and textural classification of the soils are shown in Tables 2, 3 and 4. The textural classification of these soil samples was obtained using the classification system of U.S. 


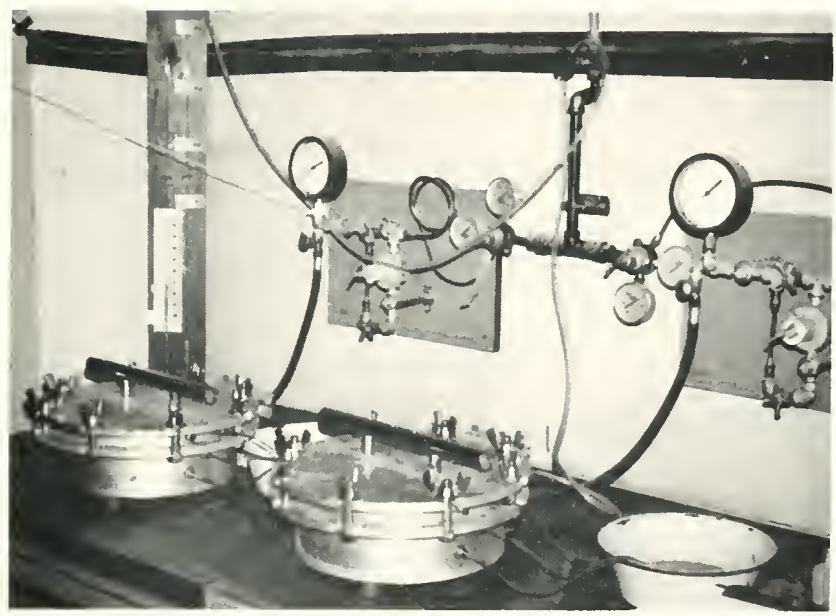

FIGURE 2. SET UP OF EQUIPMENT SHOWING TWO EXTRACTORS 


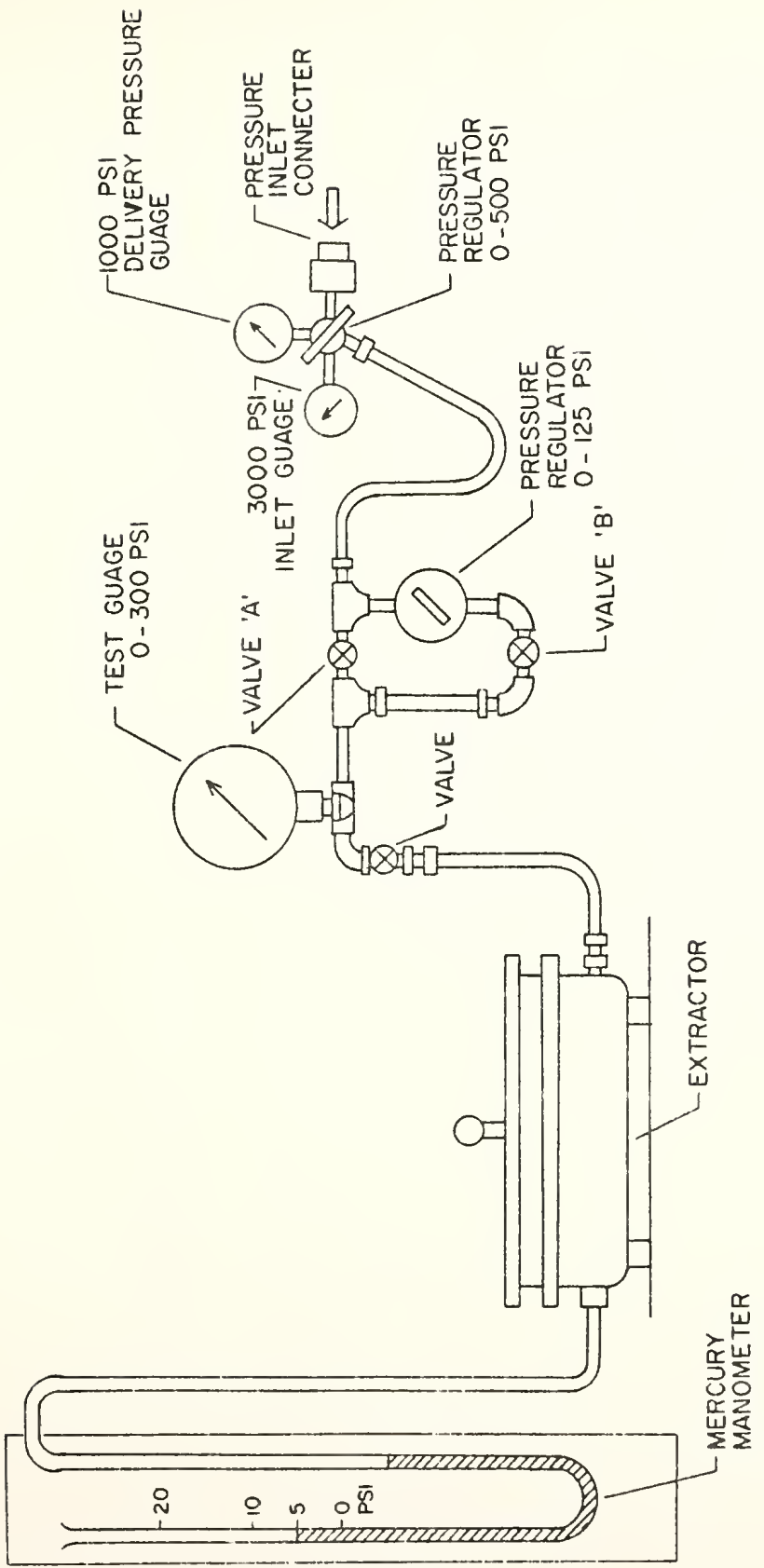

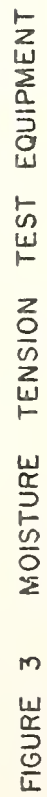


Table 2. Sieve Analysis of the Natural Solls

\begin{tabular}{|c|c|c|c|c|c|}
\hline \multirow[b]{2}{*}{ Soil No. } & \multicolumn{5}{|c|}{ Percent Passing Sieve or Size } \\
\hline & $\# 40$ & $\# 100$ & $\# 200$ & $0.05^{\mathrm{mm}}$ & $0.005^{\mathrm{mm}}$ \\
\hline 1 & 99 & 98 & 97 & 97 & 50 \\
\hline 2 & 99 & 98 & 96 & 92 & 46 \\
\hline 3 & 97 & 94 & 88 & 84 & 39 \\
\hline 4 & 96 & 67 & 59. & 58 & 37 \\
\hline 5 & 96 & 73 & 61 & 58 & 35 \\
\hline 6 & 81 & 56 & 51 & 51 & 31 \\
\hline 7 & 83 & 53 & 45 & 44 & 35 \\
\hline 8 & 84 & 55 & 46 & 44 & 33 \\
\hline 9 & 93 & 87 & 83 & 80 & 24 \\
\hline 10 & 91 & 74 & 68 & 65 & 21 \\
\hline 11 & 75 & 62 & 52 & 48 & 23 \\
\hline 12 & 84 & 75 & 60 & 49 & 22 \\
\hline 13 & 90 & 63 & 56 & 51 & 22 \\
\hline 14 & 92 & 62 & 53 & 50 & 19 \\
\hline 15 & 77 & 53 & 47 & 44 & 26 \\
\hline 16 & 98 & 60 & 52 & 48 & 21 \\
\hline 17 & 81 & 56 & 46 & 43 & 32 \\
\hline 18 & 80 & 54 & 42 & 38 & 24 \\
\hline 19 & 91 & 42 & 29 & 26 & 24 \\
\hline 20 & 96 & 50 & 36 & 33 & 14 \\
\hline 21 & 90 & 44 & 24 & 24 & 18 \\
\hline 22 & 40 & 25 & 25 & 25 & 17 \\
\hline 23 & 100 & 35 & 20 & 18 & 16 \\
\hline 24 & 95 & 32 & 13 & 12 & 11 \\
\hline 25 & 40 & 13 & 9 & 9 & 8 \\
\hline 26 & 45 & 15 & 13 & 12 & 9 \\
\hline 27 & 93 & 40 & 18 & 16 & 15 \\
\hline
\end{tabular}


Table 3. Textural Classification of the Natural Soils

\begin{tabular}{|c|c|c|c|c|}
\hline Soil No. & $\begin{array}{c}\text { Sand } \\
2.000 .05^{\mathrm{mm}} \\
(\%)\end{array}$ & $\begin{array}{c}\text { Silt } \\
0.05 n 0.005^{\mathrm{mm}} \\
(\%)\end{array}$ & $\begin{array}{c}\text { Clay } \\
-0.005^{\mathrm{mm}} \\
(\%)\end{array}$ & Textural Group \\
\hline 1 & 8 & 42 & 50 & \multirow{8}{*}{ Clay } \\
\hline 2 & 8 & 46 & 46 & \\
\hline 3 & 15 & 46 & 39 & \\
\hline 4 & 43 & 21 & 36 & \\
\hline 5 & 42 & 23 & 35 & \\
\hline 6 & 46 & 21 & 33 & \\
\hline 7 & 54 & 10 & 36 & \\
\hline 8 & 54 & 11 & 35 & \\
\hline 9 & 20 & 56 & 24 & Silty Clay Loam \\
\hline 10 & 33 & 45 & 22 & \multirow{4}{*}{ Clay Loam } \\
\hline 11 & 48 & 26 & 26 & \\
\hline 12 & 47 & 29 & 24 & \\
\hline 13 & 48 & 30 & 22 & \\
\hline 14 & 49 & 32 & 19 & Loam \\
\hline 15 & 52 & 20 & 28 & \multirow{5}{*}{ Sandy Clay Loam } \\
\hline 16 & 53 & 26 & 21 & \\
\hline 17 & 54 & 17 & 29 & \\
\hline 18 & 60 & 14 & 26 & \\
\hline 19 & 74 & 3 & 23 & \\
\hline 20 & 67 & 19 & 14 & \multirow{3}{*}{ Sandy Loam } \\
\hline 21 & 76 & 6 & 18 & \\
\hline 22 & 75 & 8 & 17 & \\
\hline 23 & 81 & 2 & 17 & \multirow{5}{*}{ Sand } \\
\hline 24 & 88 & 1 & 11 & \\
\hline 25 & 88 & 1 & 11 & \\
\hline 26 & 88 & 3 & 9 & \\
\hline 27 & 84 & 1 & 15 & \\
\hline 28 & - & -- & -- & Unclassified \\
\hline
\end{tabular}


Table 4. Textural Classification of the Artificially Prepared Soils

\begin{tabular}{|c|c|c|c|c|}
\hline Soil No. & $\begin{array}{c}\text { Sand } \\
2.000 .05^{\mathrm{mm}} \\
(\%)\end{array}$ & $\begin{array}{c}\text { S1.t } \\
0.05 \sim 0.005^{\mathrm{mm}} \\
(\%)\end{array}$ & $\begin{array}{c}\text { Clay } \\
-0.005^{\mathrm{mm}} \\
(\%)\end{array}$ & Textural Group \\
\hline $1-75$ & 28 & 31 & 41 & Clay \\
\hline $1-50$ & 47 & 21 & 32 & \\
\hline $9-75$ & 36 & 42 & 22 & \\
\hline $10-75$ & 46 & 27 & 27 & Clay Loam \\
\hline $1-25$ & 66 & 11 & 23 & \\
\hline$(1-15) *$ & 73 & 7 & 20 & \\
\hline $7-50$ & 68 & 6 & 26 & \\
\hline$(7-25)^{*}$ & 76 & 4 & 20 & \\
\hline$(8-75) *$ & 61 & 9 & 30 & \\
\hline $8-50$ & 68 & 7 & 25 & \\
\hline$(8-25) *$ & 76 & 4 & 20 & \\
\hline $10-50$ & 58 & 20 & 22 & Sandy Clay Loam \\
\hline $11-75$ & 56 & 22 & 22 & \\
\hline$(11-50) *$ & 65 & 15 & 20 & \\
\hline $15-75$ & 59 & 16 & 25 & \\
\hline $15-50$ & 67 & 12 & 21 & \\
\hline $17-75$ & 61 & 13 & 26 & \\
\hline $17-50$ & 68 & 9 & 23 & \\
\hline $7-75$ & 61 & 8 & 31 & \\
\hline$(8-75)^{*}$ & 61 & 9 & 30 & Sandy Clay \\
\hline$(1-15) *$ & 73 & 7 & 20 & \\
\hline$(7-25) *$ & 76 & 4 & 20 & \\
\hline$(8-25) *$ & 76 & 4 & 20 & \\
\hline $9-50$ & 52 & 29 & 19 & \\
\hline $9-25$ & 68 & 15 & 17 & \\
\hline $10-25$ & 71 & 12 & 17 & Sandy Loam \\
\hline$(11-50)^{*}$ & 65 & 15 & 20 & \\
\hline $11-25$ & 74 & 8 & 18 & \\
\hline $15-25$ & 75 & 7 & 18 & \\
\hline $17-25$ & 76 & 5 & 19 & \\
\hline
\end{tabular}

*Parentheses Indicate the solls which could be classified in more than one textural group. 
Bureau of Public Roads as illustrated in Figures 4 and 5 . In Tables 2 and 3 , twenty eight soils obtained from different locations of the state of Indiana are listed. These twenty eight soils will hereafter be called "natural" soil samples.

Table 4 shows the soil samples produced by mixing some of the natural soils with varying amounts of sand; these were called artificially prepared soils. Twenty nine soil samples were produced by mixing. In Table 4 the sample numbers shown in parentheses are for the soil samples which could be classified in more than one textural groups.

In numbering these artificially prepared soil samples, the first number preceding the hyphen indicates the natural soil No. which is combined with the sand (No. 27) and the last number indicates the weight percentage of the natural soil (passing $\# 40$ sieve) in the final mix. For example, soil No. 1-75 is for the soil which is made up by mixing 75 percent of soil No. 1 with 25 percent of sand (No. 27). In all cases fust the material passing the No. 40 mesh sieve was used. 


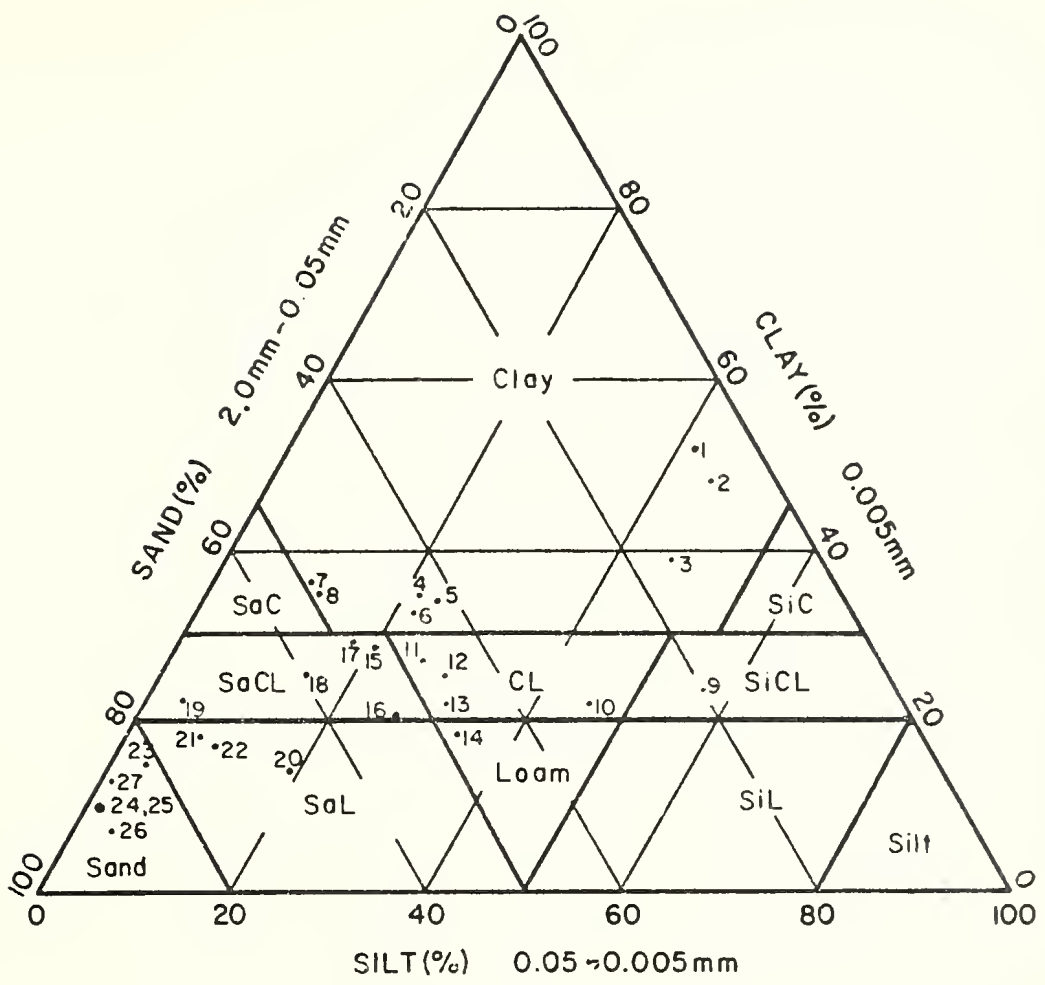

NOTE: NUMBERS NEXT TO DATA POINTS ARE SOIL NUMBERS

FIGURE 4 TEXTURAL CLASSIFICATION OF THE NATURAL SOILS 


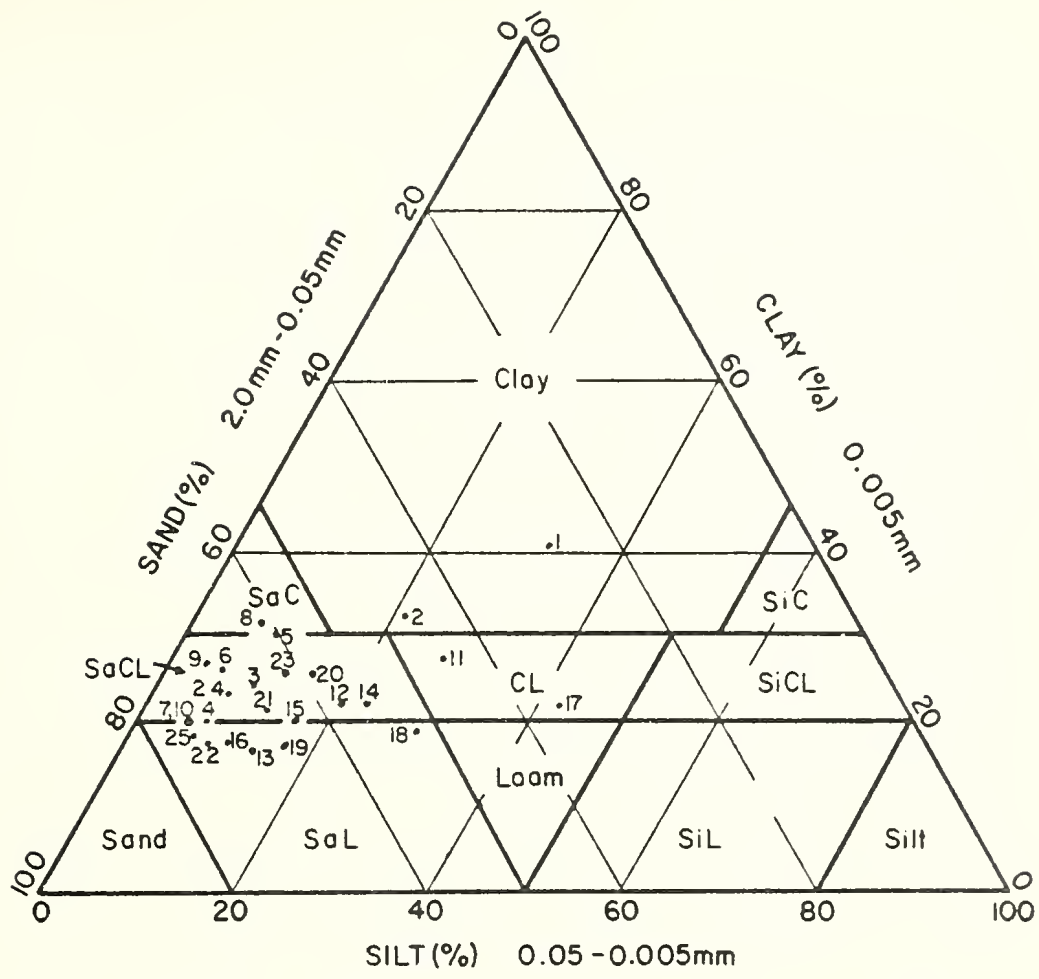

NOTE: NUMBERS IN THE CHART CORRESPOND TO SOIL NUMBERS AS GIVEN BELOW. (SEE ALSO TABLE 4)
I. $1-75$
8. $7-75$
14. $11-75$
20. $15-75$
2. $1-50$
9. $7-50$
15. $11-50$
21. $15-50$
3. $1-75$
10. $7-25$
16. $11-25$
22. $15-25$
4. $1-15$
11. $10-75$ 17. $9-75$
23. $17-75$
5. $8-75$
12. $10-50$
$\begin{array}{lll}\text { 18. } 9-50 & 24.17-50\end{array}$
6. $8-50$
13. $10-25$
19. $9-25$
25. $17-25$
7. $8-25$ 
PROCEDURES AND TESTS CONDUCTED

\section{Standard Test for Consistency Limits of Soils}

The tests to determine both the liquid and the plastic limits of the soil samples were conducted in accordance with ASTM D423-61T (1) and ASTM D-424-59 (2) respectively.

\section{Moisture Tension Test}

\section{Preparation}

All soil samples to be tested were sieved through the No. 40 sieve and only the portion passing the No. 40 sieve was used for the moisture tension tests.

Each soil sample is put into a glass jar filled with distilled water. To aid in extracting air from the soil particles, the sample and water were first agitated with a spoon. The soil was left standing for 24 hours with approximately 1 " height of excess water. About $50 \mathrm{gm}$ of soil was necessary for one run of test.

After a period of 24 hours the excess water on the surface of the soil in the jar was removed taking care not to disturb the soil sample in the jar. The ceramic plates were wetted with distilled water prior to placing the soil on the plate. A sufficient amount of soil was placed in the rubber ring on the plate using a spoon. The ceramic plate was then placed in the extractor, all the tubes connected and the lid of the extractor closed and tightened with bolts. 


\section{Application of Pressures}

After the soil on the plates is placed in the extractor, air pressure was applied to the soll samples in the extractor. During this process excess water and the water in the soll samples are forced out of the extractor through the outflow tubes which are connected with the ceramic plate cells. The pressure was maintained for 24 hours to reach an equilibrium state. The lid of the extractor was opened after 24 hours and the soil samples were transferred from the plate to a container using a spatula. The moisture content of these soil samples was determined in accordance w1th ASTM D2216-63T. The water contents of these soil samples was recorded and the pressure specified along with the water content. For example $W_{3}$ disipates the water content obtained under a pressure of 3 psi.

\section{Tests for Moisture Tension Curves}

To determine the relationship between water content of the soil samples and the pressure applied to the samples, different intensities of pressure were used in the tests. In this study, the pressure intensities were varied between $0.4 \mathrm{psi}$ and $47 \mathrm{psi}$. Two procedures to apply pressures were used. One is called "a step application of pressure" and the other is "an immediate application of pressure".

In the first procedure, the pressure was started with the lowest intensity of pressure and the pressures were increased step by step to the maximum intensity. In this method, all samples to be tested were prepared on the same day since the number of the samples to be prepared on a certain day is the same as the number of the levels of the pressure to be applied. 
To illustrate the above, for example, assume five levels of pressure such as $0.5,1.0,2.0,5.0$ and $10.0 \mathrm{ps} 1$ are to be applied. Using this method, five samples need to be prepared (if no replicates are desired) prior to applying the pressures. All of these samples are placed on the ceramic plate on the same day and the first pressure to be applied must be $0.5 \mathrm{psi}$. After 24 hours under $0.5 \mathrm{psi}$, one 3011 sample is taken out to determine the water content of the soll under 0.5 psi but the other four samples are left in the apparatus. Then the pressure of $1.0 \mathrm{psi}$ is applied, and after 24 hours a sample is taken out and the other three are left. This is continued until all intensities of pressure have been applied and the water content of the soil is determined for each pressure.

The other procedure was to apply the pressure to the sample just once. The sample, thus, was always fresh and had not been subjected to any other pressure prior to the test.

For instance, only one sample may be prepared on the first day if no replicates are desired. Suppose $2.0 \mathrm{psi}$ of pressure is chosen and applied to the first sample. On the next day another sample is prepared for the next pressure, say $0.5 \mathrm{ps} 1$, and so on until all pressures are used and the water content is determined for these pressures. Thus, any pressure can be chosen to be applied first by this method.

\section{Tests for Time Factor Study}

The purposes of this study were twofold, (I) to find out if a savings in time could be realized by using a higher pressure and (2) make certain that sufficient time was used so that equilibrium was reached. 
For this study, four kinds of soils which were expected to require relatively longer equilibrium time were chosen and three different Intensities of pressure $(1.0,2.0$ and $4.0 \mathrm{psi})$ were applied. Measurements were done after seven different periods such as 1, 2, 4, 14, 24 , 36 and 48 hours. A replicate test was made on each sample.

For each soil and each pressure, fourteen samples were prepared on the same day because seven stages of loading time and a replicate for each were used. These fourteen samples were placed in the extractor and the first pressure was applied (say 1.0 psi). After one hour (first loading period), two samples were taken out to determine the water contents under 1.0 psi for one hour. After 2 hours, two more samples were taken out. This was continued and the last two samples were taken out after 48 hours of pressure application and their water contents were determined.

\section{Tests for Prediction Curves of Atterberg Limits}

To obtain prediction curves of the liquid limit, the plastic limit and the plasticity index of soils, by the molsture tension method, two intensities of pressure ( 3 psi and $20 \mathrm{psi})$ were selected. An amount of soil sample necessary for two runs of the test was prepared. Half of this amount was used for the 3 psi pressure and the other half for the 20 psi pressure. The tests were run according to the procedure described earlier. 
RESULTS

\section{Consistency Limits by the Standard Method}

Both the liquid and plastic limits were determined for the twenty seven natural soils (see Table 5) and thirty artificially prepared soils. Several operators ran the tests on different days for the natural soils, but for the artificially prepared soils, both the liquid limit and plastic limit values were determined by only one operator.

The liquid and plastic limits for the natural soils are shown in Table A-1 and Table A-2; their standard deviations and average values are shown in Table 6 and Table 7 . The test results for the artificially prepared soils are shown in Table A-3 along with the results of the moisture tension tests using 3 psi and 20 psi of pressure.

The standard liquid limits of the natural soils ranged between 19.3\% and 58.1\%. The standard deviation for each operator was approximately $1.5 \%$, the highest was $4.66 \%$ for soil No. 28 by operator C as shown in Table 6. The deviation between operators from the average value for each soil was between $5 \%$ and $10 \%$.

As for the plastic limits, the natural soils had values of between $14.0 \%$ and $29.0 \%$. The standard deviation for each operator was between $0.46 \%$ and $5.42 \%$ which was somewhat higher than it was for the liquid limits. Also the maximum deviation between operators was $15 \%$.

Table 8 and Table 9 show the cases set up for LL (Liquid Limft) and PL (Plastic Limit) respectively. These tables also show the results of this analysis in the right column. 


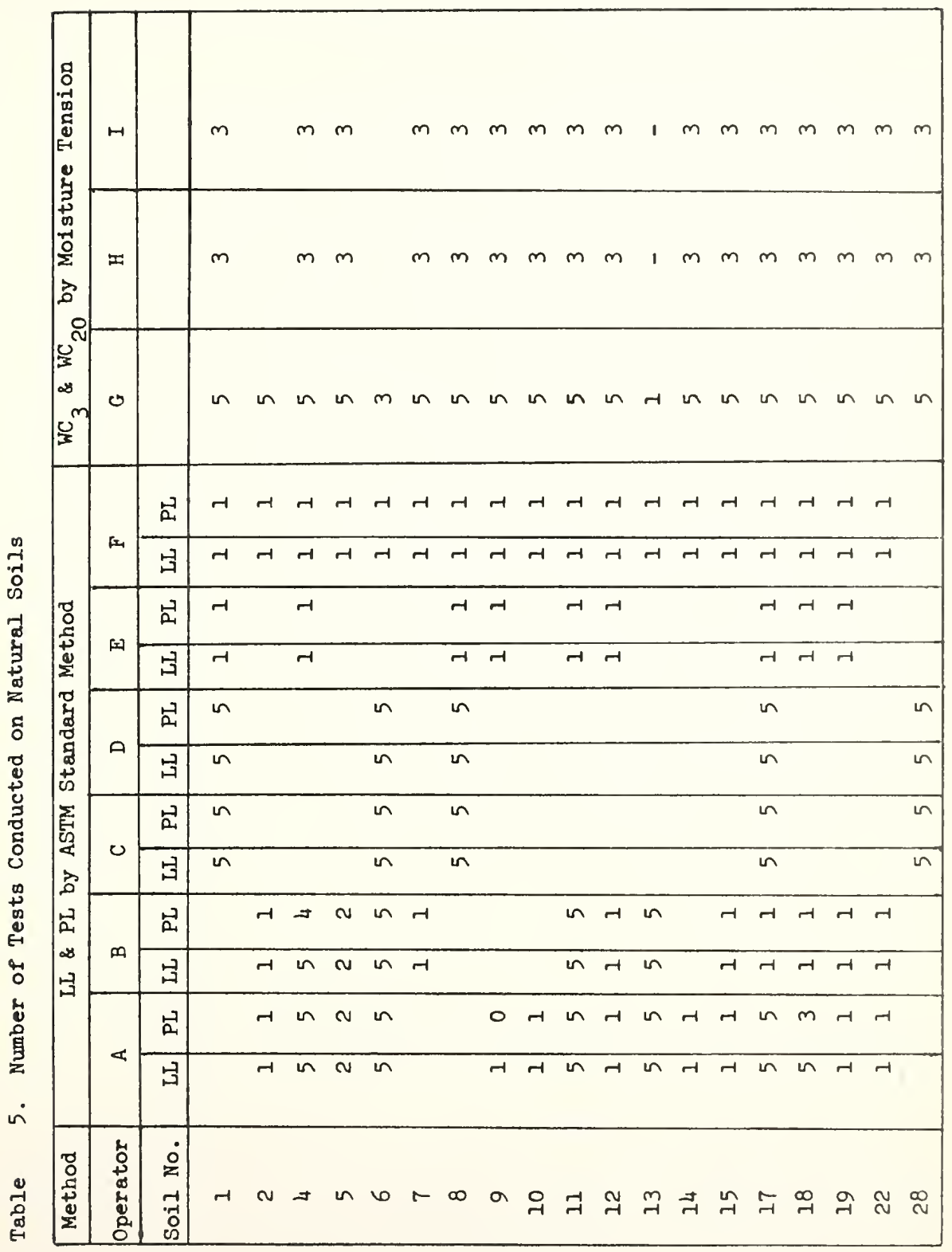


Table 6. Liquid Limit Values by Several Operators

\begin{tabular}{|c|c|c|c|c|c|c|c|}
\hline Operator & $\begin{array}{l}A \\
(\%)\end{array}$ & $\begin{array}{l}\mathrm{B} \\
(\%) \\
\end{array}$ & $\begin{array}{c}\mathrm{C} \\
(\%) \\
\end{array}$ & $\begin{array}{l}\mathrm{D} \\
(\%) \\
\end{array}$ & $\begin{array}{l}\mathrm{E} \\
(\%) \\
\end{array}$ & $\begin{array}{c}F \\
(\%)\end{array}$ & \begin{tabular}{|c|} 
Grand \\
Average \\
$(\%)$ \\
\end{tabular} \\
\hline 1 & & & $\begin{array}{l}49.4 \\
(4.07) \\
\end{array}$ & $\begin{array}{l}50.4 \\
(1.69) \\
\end{array}$ & 51.0 & 48.0 & 50.0 \\
\hline 2 & & 38.5 & & & & 47.8 & 43.2 \\
\hline 4 & $\begin{array}{l}27.9 \\
(1.01)\end{array}$ & $\begin{array}{l}28.0 \\
(0.77)\end{array}$ & & & 31.1 & 34.8 & 28.8 \\
\hline 5 & $\begin{array}{l}25.1 \\
(0.57)\end{array}$ & $\begin{array}{l}25.2 \\
(1.20) \\
\end{array}$ & & & & 24.5 & 25.0 \\
\hline 6 & $\begin{array}{l}27.4 \\
(1.24)\end{array}$ & $\begin{array}{l}27.1 \\
(1.06)\end{array}$ & $\begin{array}{l}29.6 \\
(1.51)\end{array}$ & $\begin{array}{l}27.6 \\
(0.97)\end{array}$ & & 32.2 & 28.1 \\
\hline 7 & & 26.3 & & & & 27.7 & 27.0 \\
\hline 8 & & & $\begin{array}{l}27.9 \\
(0.30)\end{array}$ & $\begin{array}{l}30.0 \\
(1.11) \\
\end{array}$ & 27.5 & 26.5 & 28.7 \\
\hline 9 & 30.4 & & & & & 30.5 & 30.5 \\
\hline 10 & 21.5 & & & & & 18.7 & 20.1 \\
\hline 11 & $\begin{array}{l}20.3 \\
(0.51)\end{array}$ & $\begin{array}{l}19.8 \\
(0.48) \\
\end{array}$ & & & 20.8 & 20.8 & 20.2 \\
\hline 12 & 23.5 & 22.2 & & & 21.4 & 22.6 & 22.4 \\
\hline 13 & $\begin{array}{l}42.2 \\
(1.34)\end{array}$ & $\begin{array}{l}41.4 \\
(1.59) \\
\end{array}$ & & & & 39.2 & 41.6 \\
\hline 14 & 18.4 & & & & & 27.7 & 18.1 \\
\hline 15 & 25.8 & 20.3 & & & & 19.5 & 21.9 \\
\hline 16 & & & & & & N.P. & \\
\hline 17 & $\begin{array}{l}19.1 \\
(0.35)\end{array}$ & 19.0 & $\begin{array}{l}19.7 \\
(0.78) \\
\end{array}$ & $\begin{array}{l}19.5 \\
(0.38) \\
\end{array}$ & 18.4 & 18.6 & 19.3 \\
\hline 18 & $\begin{array}{l}23.4 \\
(1.25) \\
\end{array}$ & 22.9 & & & 20.5 & 23.0 & 23.0 \\
\hline 19 & 30.8 & 27.6 & & & 29.4 & 24.8 & 28.2 \\
\hline 20 & N.P. & & & & & N.P. & \\
\hline
\end{tabular}


Table 6, cont.

\begin{tabular}{|c|c|c|c|c|c|c|c|}
\hline Soil & $\begin{array}{l}\text { A } \\
(\%) \\
\end{array}$ & $\begin{array}{l}B \\
(\%) \\
\end{array}$ & $\begin{array}{l}\mathrm{C} \\
(\%) \\
\end{array}$ & $\begin{array}{r}D \\
(\%) \\
\end{array}$ & $\begin{array}{l}E \\
(\%) \\
\end{array}$ & $\begin{array}{l}F \\
(\%) \\
\end{array}$ & $\begin{array}{c}\text { Grand } \\
\text { Average } \\
(\%)\end{array}$ \\
\hline 21 & N.P. & & & & & N.P. & \\
\hline 22 & 24.9 & 22.7 & & & & 20.9 & 22.8 \\
\hline 23 & N.P. & & & & & N.P. & \\
\hline 24 & N.P. & & & & & N.P. & \\
\hline 25 & N.P. & & & & & N.P. & \\
\hline 26 & N.P. & & & & & N.P. & \\
\hline 27 & N.P. & & & & & N.P. & \\
\hline 28 & & & $\begin{array}{l}58.7 \\
(4.66)\end{array}$ & $\begin{array}{l}57.5 \\
(0.78) \\
\end{array}$ & & & 58.1 \\
\hline
\end{tabular}

(Numbers in parentheses are standard deviation.) 
Table 7. Plastic Limit Values by Several Operators

\begin{tabular}{|c|c|c|c|c|c|c|c|}
\hline Soil & $\begin{array}{l}A \\
(\not)\end{array}$ & $\begin{array}{l}\mathrm{B} \\
(\%) \\
\end{array}$ & $\begin{array}{l}\mathrm{C} \\
(\%) \\
\end{array}$ & $\begin{array}{l}D \\
(\%) \\
\end{array}$ & $\begin{array}{c}E \\
(\%) \\
\end{array}$ & $\begin{array}{c}F \\
(\%) \\
\end{array}$ & $\begin{array}{c}\text { Grand } \\
\text { Average } \\
(\%)\end{array}$ \\
\hline 1 & & & $\begin{array}{l}29.7 \\
(2.06)\end{array}$ & $\begin{array}{l}28.8 \\
(1.76) \\
\end{array}$ & 29.2 & 25.8 & 28.9 \\
\hline 2 & 28.8 & 16.8 & & & & 26.3 & 27.6 \\
\hline 4 & $\begin{array}{l}15.6 \\
(2.13)\end{array}$ & $12.5^{*}$ & & & 14.4 & 17.9 & 15.7 \\
\hline 5 & $\begin{array}{l}15.7 \\
(1.13)\end{array}$ & $13.6^{*}$ & & & & 16.6 & 16.0 \\
\hline 6 & $\begin{array}{l}15.9 \\
(2.88) \\
\end{array}$ & $14.4 *$ & $\begin{array}{l}21.0 \\
(1.09)\end{array}$ & $\begin{array}{l}18.4 \\
(0.65)\end{array}$ & & 16.3 & 18.3 \\
\hline 7 & & 11.9 " & & & & 16.4 & 16.4 \\
\hline 8 & 13.2 & & $\begin{array}{l}16.8 \\
(0.53) \\
\end{array}$ & $\begin{array}{l}15.8 \\
(0.88)\end{array}$ & 14.0 & 16.4 & 15.9 \\
\hline 9 & & & & & 23.5 & 25.3 & 24.4 \\
\hline 10 & N.P. & & & & & N.P. & \\
\hline 11 & $\begin{array}{l}13.7 \\
(1.38)\end{array}$ & $11.7^{\circ}$ & & & 14.8 & 15.5 & 14.1 \\
\hline 12 & 14.8 & $13.5^{*}$ & & & 17.7 & 20.4 & 17.6 \\
\hline 13 & $\begin{array}{l}33.7 \\
(2.55)\end{array}$ & $29.2^{*}$ & & & 31.5 & & 33.4 \\
\hline 14 & N.P. & & & & & N.P. & \\
\hline 15 & 16.7 & $10.1 "$ & & & & 13.9 & 15.3 \\
\hline 16 & & & & & & N.P. & \\
\hline 17 & $\begin{array}{l}13.1 \\
(1.00) \\
\end{array}$ & 11.0 & $\begin{array}{l}14.9 \\
(0.65)\end{array}$ & $\begin{array}{l}14.0 \\
(0.46)\end{array}$ & 13.9 & 13.4 & 14.0 \\
\hline 18 & $\begin{array}{l}16.5 \\
(2.25) \\
\end{array}$ & $11.4 *$ & & & 14.7 & 15.2 & 15.9 \\
\hline 19 & 21.2 & $14.0^{*}$ & & & 18.2 & & 19.7 \\
\hline 20 & N.P. & & & & & N.P. & \\
\hline
\end{tabular}


Table 7 , cont.

\begin{tabular}{|c|c|c|c|c|c|c|c|}
\hline Operator & $\begin{array}{c}A \\
(\%) \\
\end{array}$ & $\begin{array}{c}\mathrm{B} \\
(\%) \\
\end{array}$ & $\begin{array}{l}\mathrm{C} \\
(\%) \\
\end{array}$ & $\begin{array}{l}\text { D } \\
(\%)\end{array}$ & $\begin{array}{l}E \\
(\%) \\
\end{array}$ & $\begin{array}{l}F \\
(\%) \\
\end{array}$ & $\begin{array}{c}\text { Grand } \\
\text { Average } \\
(\%)\end{array}$ \\
\hline 21 & N.P. & & & & & N.P. & \\
\hline 22 & 18.0 & $13.8^{*}$ & & & & 17.0 & 17.5 \\
\hline 23 & N.P. & & & & & N.P. & \\
\hline 24 & N.P. & & & & & N.P. & \\
\hline 25 & N.P. & & & & & N.P. & \\
\hline 26 & N.P. & & & & & N.P. & \\
\hline 27 & N.P. & & & & & N.P. & \\
\hline 28 & & & $\begin{array}{l}29.3 \\
(5.42) \\
\end{array}$ & $\begin{array}{l}28.8 \\
(1.04) \\
\end{array}$ & & & 29.0 \\
\hline
\end{tabular}

* Operator B's data is not included in calculation of the average. 
Table

8. Tests for Operator Effect (LL)

\begin{tabular}{|c|c|c|c|c|c|}
\hline Case & Test Method & Operators & Soll No. & $\begin{array}{c}\text { No. of } \\
\text { Replicas }\end{array}$ & Result \\
\hline 1 & Two-way ANOVA & $A, B, C, D$ & 6,17 & $1 \& 5$ & Not Reject \\
\hline 2 & Two-way ANOVA & $A, B$ & $\begin{array}{l}4,5,6,11, \\
13,18\end{array}$ & $\begin{array}{l}1 \text { or } 2 \\
\text { or } 5\end{array}$ & Not Reject \\
\hline 3 & Two-way ANOVA & $C, D$ & $\begin{array}{l}1,6,8,17, \\
28\end{array}$ & 5 & Not Reject \\
\hline 4 & t-test & $A, B$ & $12,15,19,22$ & 1 & Not Reject \\
\hline 5 & $t$-test & $A, F$ & $\begin{array}{l}2,9,10,12, \\
14,15,22\end{array}$ & 1 & Not Reject \\
\hline 6 & t-test & $\mathrm{B}, \mathrm{F}$ & $\begin{array}{l}2,7,12,15, \\
17,18,19,22\end{array}$ & 1 & Not Reject \\
\hline 7 & t-test & $E, F$ & $\begin{array}{l}1,4,8,11, \\
12,17,18,19\end{array}$ & 1 & Not Reject \\
\hline
\end{tabular}

Table 9. Tests for Operator Effect (PL)

\begin{tabular}{|c|c|c|c|c|c|}
\hline Case & Test Method & Operators & Soil No. & $\begin{array}{c}\text { No. of } \\
\text { Replices }\end{array}$ & Result \\
\hline 1 & Two-way ANOVA & $A, B, C, D$ & 6,17 & $1 \& 5$ & Not Reject \\
\hline 2 & Two-way ANOVA & $A, B$ & $\begin{array}{l}4,5,6,11 \\
13,18\end{array}$ & $\begin{array}{l}1 \text { or } 2 \\
\text { or } 5\end{array}$ & Reject \\
\hline 3 & Two-way ANOVA & $C, D$ & $\begin{array}{l}1,6,8,17, \\
28\end{array}$ & 5 & Not Reject \\
\hline 4 & Two-way ANOVA & $A, C, D$ & 6,17 & 5 & Not Reject \\
\hline 5 & t-test & $A, B$ & $12,15,19,22$ & 1 & Reject \\
\hline 6 & t-test & $A, F$ & $2,12,15,22$ & 1 & Not Reject \\
\hline 7 & t-test & $\mathrm{B}, \mathrm{F}$ & $\begin{array}{l}2,7,12,15, \\
17,18.22\end{array}$ & 1 & Not Reject \\
\hline 8 & t-test & $E, F$ & $\begin{array}{l}1,4,8,11, \\
12,17,18\end{array}$ & 1 & Not Reject \\
\hline
\end{tabular}


In the case of soils for which more than two operators obtained at least one observation, such as case 1 through case 3 (Table 8) in liquid limit, a two-way ANOVA was utilized. For the calculation the computer program UNEQUAL was utilized. All factors were assumed random models. This technique was also used in cases 1 through 4 of the plastic limit. For the soils which have only one observation by one operator, as case 4 through case 7 for the liquid limit and case 5 through case 8 for the plastic limit, t-tests were utilized. The analysis and the calculations for all cases are shown in Table B-I through Table B-4. The assumptions made are also shown.

The results of the tests of operator effect are shown in the right column in Table 8 for liquid limit and Table 9 for plastic limit. As for the liquid limits, the null hypothesis that "technique of each operator has no effect" was accepted. In other words, there was no significant difference between the operators tested in each case. For the plastic limits, case 2 and case 5 were rejected. By examining the original data for both cases, it was seen that the plastic limits obtained by operator $B$ were always smaller than the others and he measured a plastic limit as low as $11 \%$. It is doubtful that a plastic limit of $11 \%$ obtained by the standard method is reliable. It seems reasonable to assume that operator B had poor or wrong techniques in obtaining plastic limits. Case 4 in Table 9 shows that the hypothesis that operator technique had no effect can be accepted when operator B's data is omitted; therefore, operator B's data will be omitted in the following analysis.

The analysis for the cases studied show that there is no significant difference due to operators in both liquid and plastic limits. 
It does not mean, however, that the observed values of the liquid and plastic limits by the standard tests were accurate or had small operator variance. This may be because of the large variances in the replicate tests that were performed by the operators. It was expected that the variance within operators would be a function of soil type which might be similar for all operators. However, such a tendency could not be observed due to limited data.

Prediction of the Plasticity of Soils by the Moisture Tension Method

In order to find prediction curves of both liquid and plastic limits of soils, the water content at equilibrium under 3 psi and 20 psi pressure in the pressure plate apparatus was determined. The tests were run for both the natural soils and the artificially prepared soils.

The data for the natural soils were obtained by three operators. One of the operators ran the tests under the same condition on five different days and the other two operators ran them on three different days. For the artificially prepared soils, one operator used both the standard method and the moisture tension method. The tests were not replicated.

All observed $W_{3}$ and $W_{20}$ by three operators are shown in Tables A-4 through A-9. Also the standard deviations among operators for each soil are shown in the same tables. The results for the artificially prepared soils is shown in Table A-3 and Figure A-1 through Figure A-3 along with the standard test results.

For the moisture tension test results, a two-way ANOVA was utilized to test operator effect on the mean value. In the analysis, both factors of operator and soil type were assumed random models. 


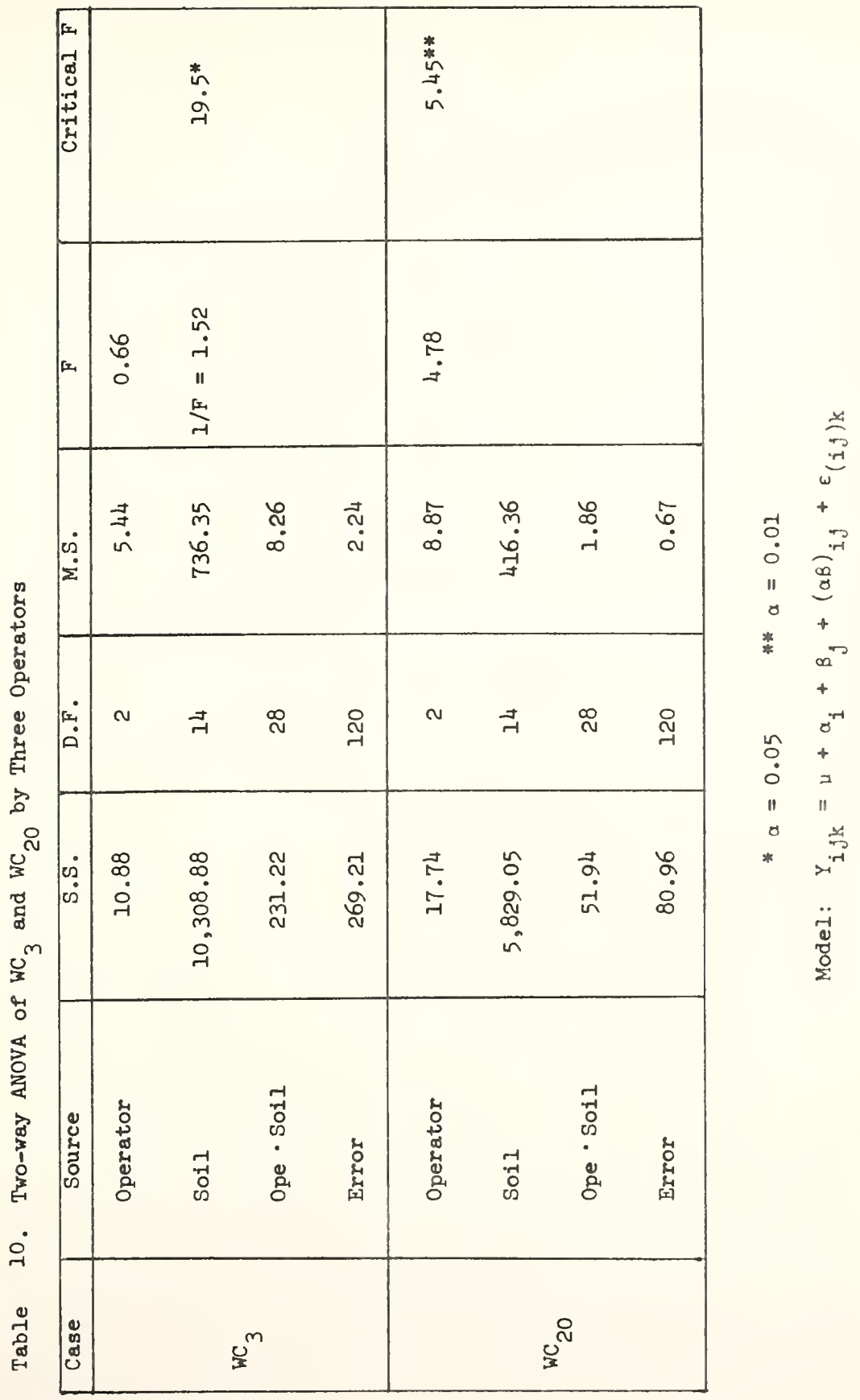


The results are shown in Table 10. According to this analysis, there is no significant difference between operators at the $99 \%$ level of significance.

In order to find prediction curves of the consistency limits of soils using the moisture tension results, a regression analysis was made using the liquid or the plastic limits as the dependent variables and $W_{3}$ and $W_{20}$ as the independent variables.

Due to the fact that the same number of tests were not made on all soils, two processes of analysis were adopted. One is called "all random combinations" and the other is called "random pull". For the artificially prepared soils, a regression analysis was made using only one observation of the liquid limit and the plastic limit for each soil and $\mathrm{WC}_{3}$ and $\mathrm{WC}_{20^{\circ}}$

For making regression analysis, BMD2R and BMD3R of computer program were utilized.

\section{All Random Combinations}

Because of the number of observations of both liquid and plastic limits as the dependent variables were not the same as those of $\mathrm{WC}_{3}$ and $\mathrm{WC}_{20}$, not all the values obtained could be used in the regression analysis. The values used in the regression analysis were obtained from the set of all available observations for each test method combined randomly. For example, the number of the liquid limits observed for soil No. I was twelve and that of $W_{3}$ and $\mathrm{WC}_{20}$ in the moisture tension method was eleven. In this case the data of soil No. I for the analysis was obtained so that the eleven observations of $\mathrm{WC}_{3}$ and $W_{20}$ were randomly combined with the eleven of the liquid limits observations out of twelve. 
An assumption made for this process, that there is no significant difference due to operator variability in both test methods, has been already discussed in the above section of this chapter. The data which were chosen from both the standard test results and the moisture tension results and combined randomly are shown in Table $\mathrm{C}-\mathrm{l}$.

Prior to starting the regression analysis, the assumption of homogeneity of variance was examined. The results are shown in Table 11 .

Table 11. Homogeneity of Variance Calculated for the Data Shown in Table C-I by the Foster-Burr Test

\begin{tabular}{|l|c|c|c|}
\hline & Calculated q & Critical Q & Result \\
\hline L.L. & 0.1179 & $0.100^{*}$ & rejected \\
\hline P.L. & 0.1001 & $0.113^{*}$ & not rejected \\
\hline \multicolumn{2}{|r|}{$* \alpha=0.05$} & $* * \alpha=0.01$
\end{tabular}

With the plastic limits as a dependent variable, the test showed no significant difference in the variance at the $95 \%$ level of significance. The homogeneity of variance test for the liquid limits, however, was violated at the $99 \%$ level of significance. Some attempts to decrease the variances of the liquid limits were made. One of them was to use a square root of the liquid limit value as a dependent variable. Another attempt was to group the soils using the relationship between $W_{3}$ and $W_{20}$. However, all were not successful. The results of the above regression analysis are shown in Table 12.

\section{Random Pull}

Another method used to correlate the consistency limits of soils with the moisture tension results was called random pull which was made 
to eliminate some shortcomings in the all random combination process. This process is one in which only one pair of $W_{3}$ and $W_{20}$ values for each soil type were chosen randomly as the independent variables from the original data, but for the dependent variables, the mean value of all observed liquid and plastic limits were used for each soil type. Thus, only one set of LI and PL and $W_{3}$ and $W_{20}$ for each soll type was used; therefore, in the case of the liquid limit, 18 cases were available for the regression analysis, this number being the same as that of the soil type. The combination chosen for the regression analysis is shown in Table $\mathrm{C}-2$. The results of the regression analysis are also summarized in Table 12.

\section{Analysis of the Artificially Prepared Soils}

For the artificially prepared soils, the standard tests and the moisture tension tests were run once by one operator. Therefore, only one set of $\mathrm{LI}$ (or PL), $\mathrm{WC}_{3}$ and $\mathrm{WC}_{20}$ for each soil type were available for regression analysis. In the above procedure the liquid limit or the plastic limit was used as the dependent variable and both $\mathrm{WC}_{3}$ and $W_{20}$ were used as the independent variables. The results of the regression analysis are shown in Table 13.

Interpretation of the Regression Analysis Results

There were a number of problems that made analysis difficult. First, sufficient numbers of data by the standard method corresponding to the number of data by the moisture tension method could not be obtained because of the length of time required to run the standard tests for a large number of samples. In some cases, no data were obtained by the same operator in both tests. 


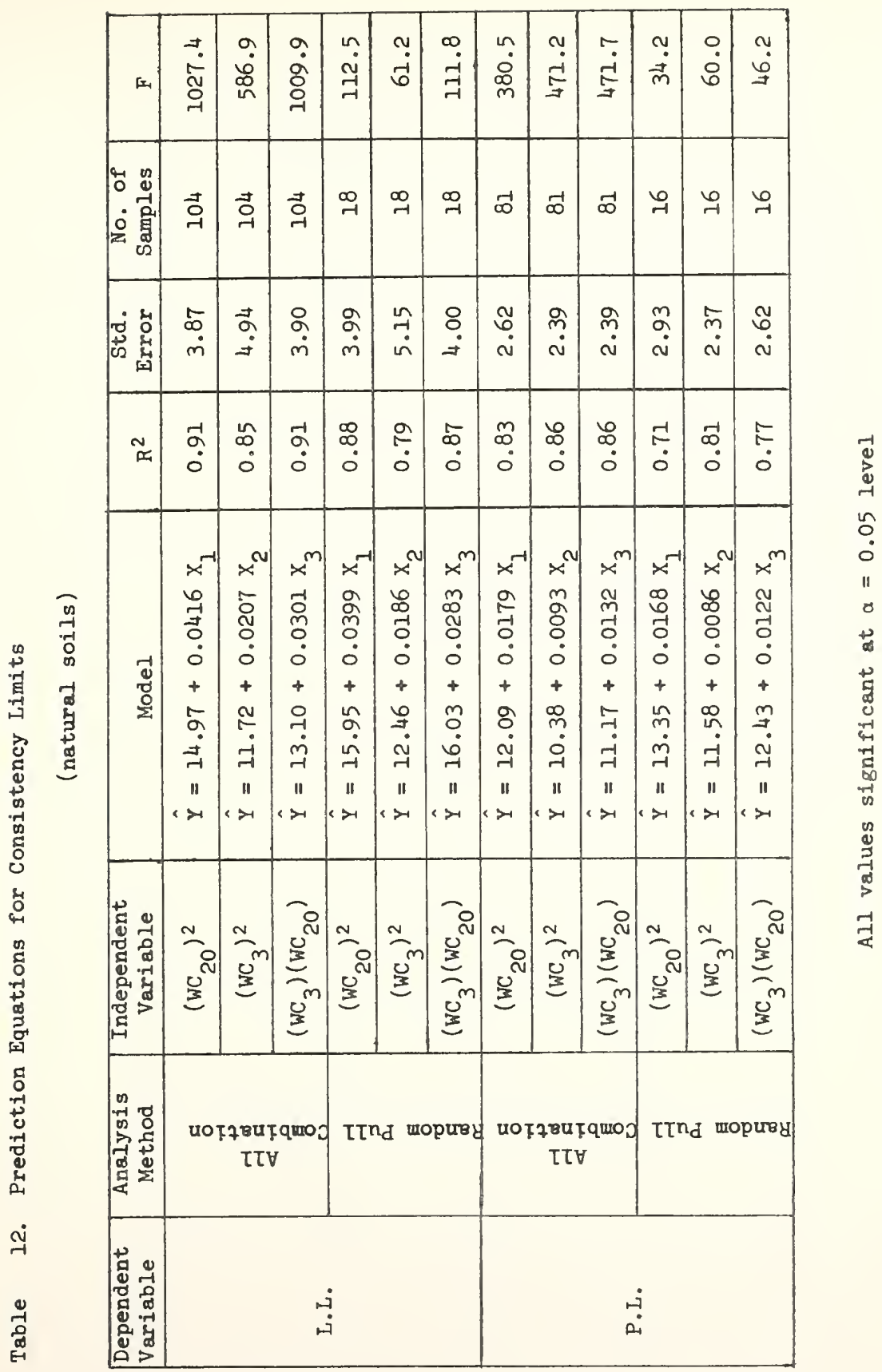




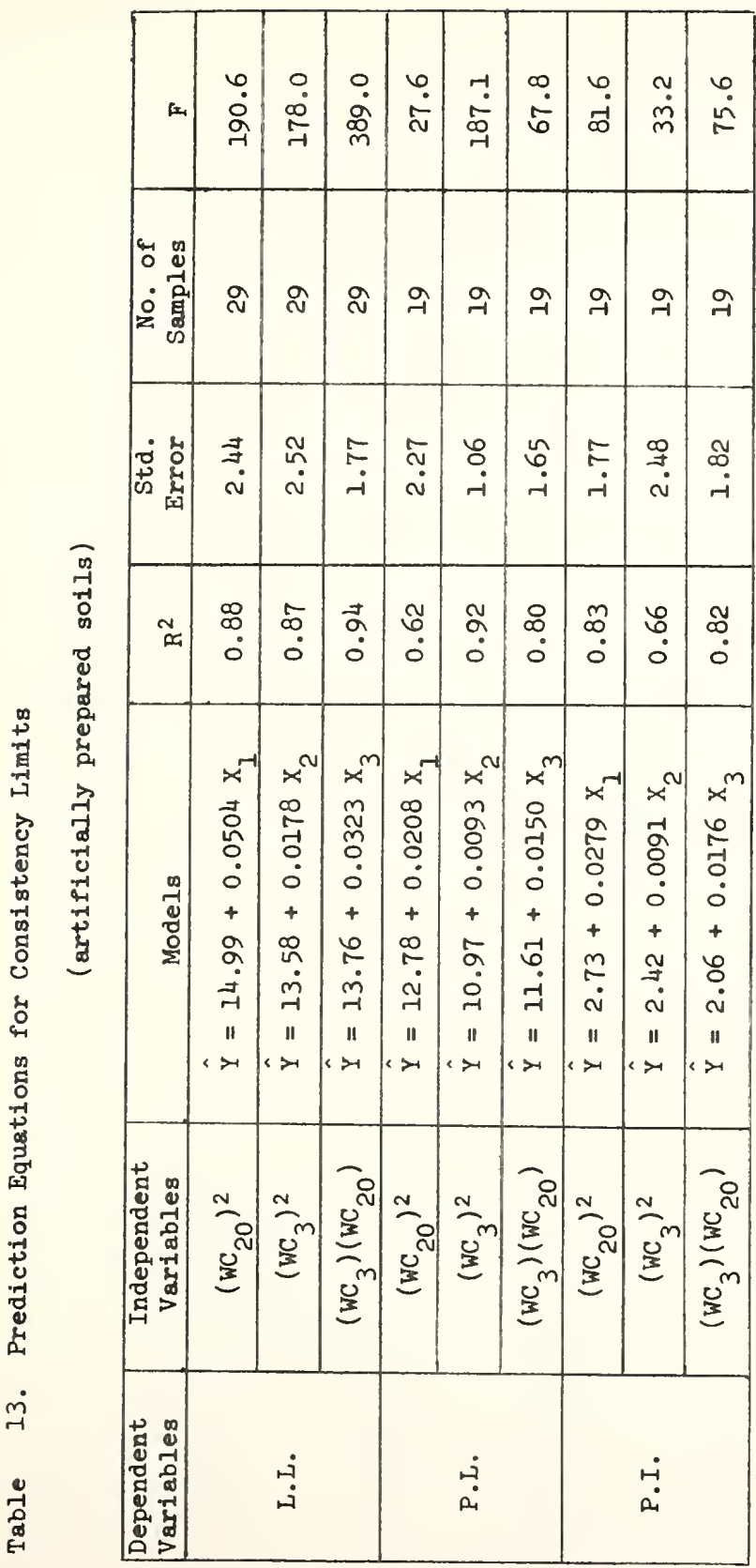

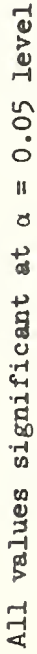




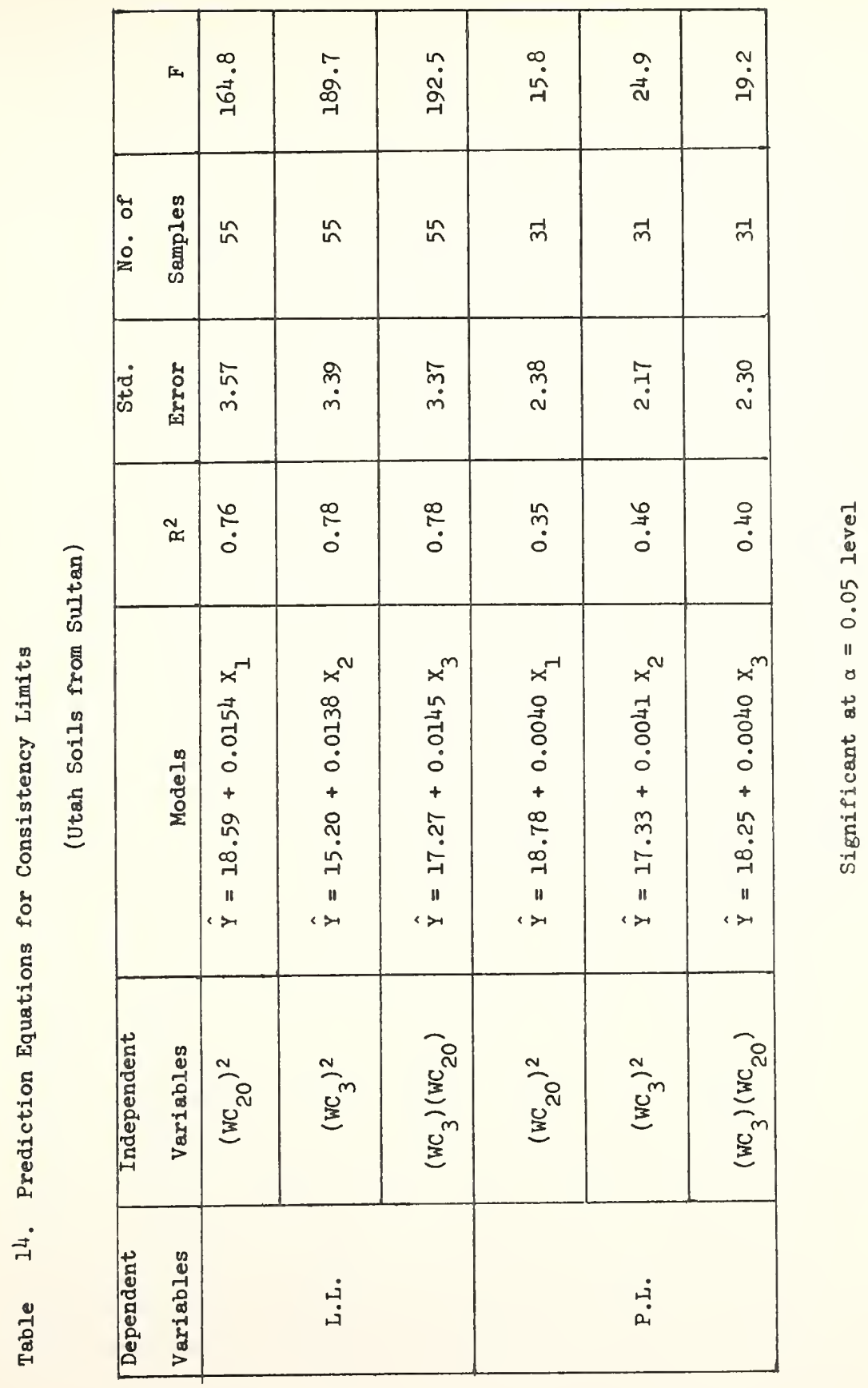


Secondly, the variances of the standard method test results among and within operators were not consistent. For some soils the results of a single operator had large variances that were not evident with other operators. In other words, no relationship could be found between soil type and operator regarding magnitude of the variance. Dawson (6) has reported, however, that the overall variation of the liquid limits values due to operator technique was as high as $\pm 5 \%$ to $\pm 10 \%$ even by experts of the standard test method.

In the "all random combination" process, the homogeneity of variance of the dependent variables (LL) was violated. This nonhomogeneity was no doubt, due to large operator variances.

In the "random pull" process the analysis was made for only one pair of observations for each soil. In this case, no consideration was given to the variance of the observed values in both test methods and the mean value of some observations was assumed to be the "true" value for each soil. The assumption for this process, that there is no significant difference due to operators has been already established in both test methods. In the analysis of the artificially prepared soils, only one observation could be used for each soil.

It is significant that the variables chosen in the regression analysis as the variables which have high correlation with both the liquid and plastic limits were $\left(W_{20}\right)^{2},\left(W C_{3}\right)^{2}$ and $\left(W C_{3}\right)\left(W C_{20}\right)$ as shown in Table 12 and Table 13. In the artificially prepared soils, for which only one observation per soil was obtained by one operator, similar results were obtained. For the plasticity index (PI), the difference of LL and PL, these variables shown above also have a relatively high correlation with PI. In Table 13, a calculated model for 
PI of the artificially prepared soils is shown. Moreover, the variables of $\left(W C_{20}\right)^{2},\left(W C_{3}\right)^{2}$ and $\left(W C_{3}\right)\left(W C_{20}\right)$ in Sultan's data (14) show high correlation with the liquid limits as shown in Table 14 . In case of the plastic limit in Sultan's data, a relatively low standard error of estimate is shown though $R^{2}$ is as low as 0.46 .

At this stage of the study, however, it is not possible to determine which model is the best. However, it is believed that reasonable values can be found to represent both the liquid and plastic limits by using one of the models.

The question of the reliability of the moisture tension tests was considered. For the originally observed values of $\mathrm{WC}_{3}$ and $\mathrm{WC}_{20}$, as discussed in the preceding sections of this section, there was no significant difference due to operators. Another test for its reliability was made by using the coefficient of variation which is denoted as the standard deviation divided by the mean value. Table D-1 through Table D-3 show these values calculated for the predicted liquid limits and plastic limits by using the equations determined in the above analysis. Comparing the coefficients of variation of the standard test results with those of the predicted values by the moisture tension method for each soil, it is seen that the latter has smaller values of the coefficient for many soil types. This tendency is quite apparent especially in the plastic limit. As a result, it can be concluded that the predicted values by the models have more, or at least as much, reliability as the standard test results. 
Prediction of Non-Plasticity by $\mathrm{WC}_{3}$ and $\mathrm{WC}_{20}$

In Figure 6 , the observed values of $W_{3}$ and $W_{20}$ for the natural and the artificially prepared soils are plotted. Arbitrarily selected boundaries have been drawn delineating the non-plastic materials from the plastic materials. Data on this figure suggest a technique for distinguishing between plastic and non-plastic materials.

\section{Some Characteristics of the Moisture Tension Method}

In this section, some characteristics observed in the moisture tension test results will be discussed qualitatively. It had been anticipated that these characteristics could be used in the prediction equations of the consistency limits of soils and, therefore, increase the reliability of prediction. The attempts to do this did not appear to improve the results. However, they will be discussed here since they should give the reader greater insight into the mechanical functioning of the moisture tension method and facilitate the undertaking of studies in this area.

\section{Shape of Moisture Tension Curves}

The moisture tension curves for various soils are shown in Figures E-I through E-10.

Many soils show two flex points on their moisture tension curves, some of them have only one flex point and others show almost a straight line relationship between $\log$ pressure and water content. As only a few curves were obtained for most soil types, full consideration could not be given to the shapes of these curves. It can be seen, for example, that for the clays, not all the curves are similar. The primary thing, that can be observed in the study for the soils which have two flex 


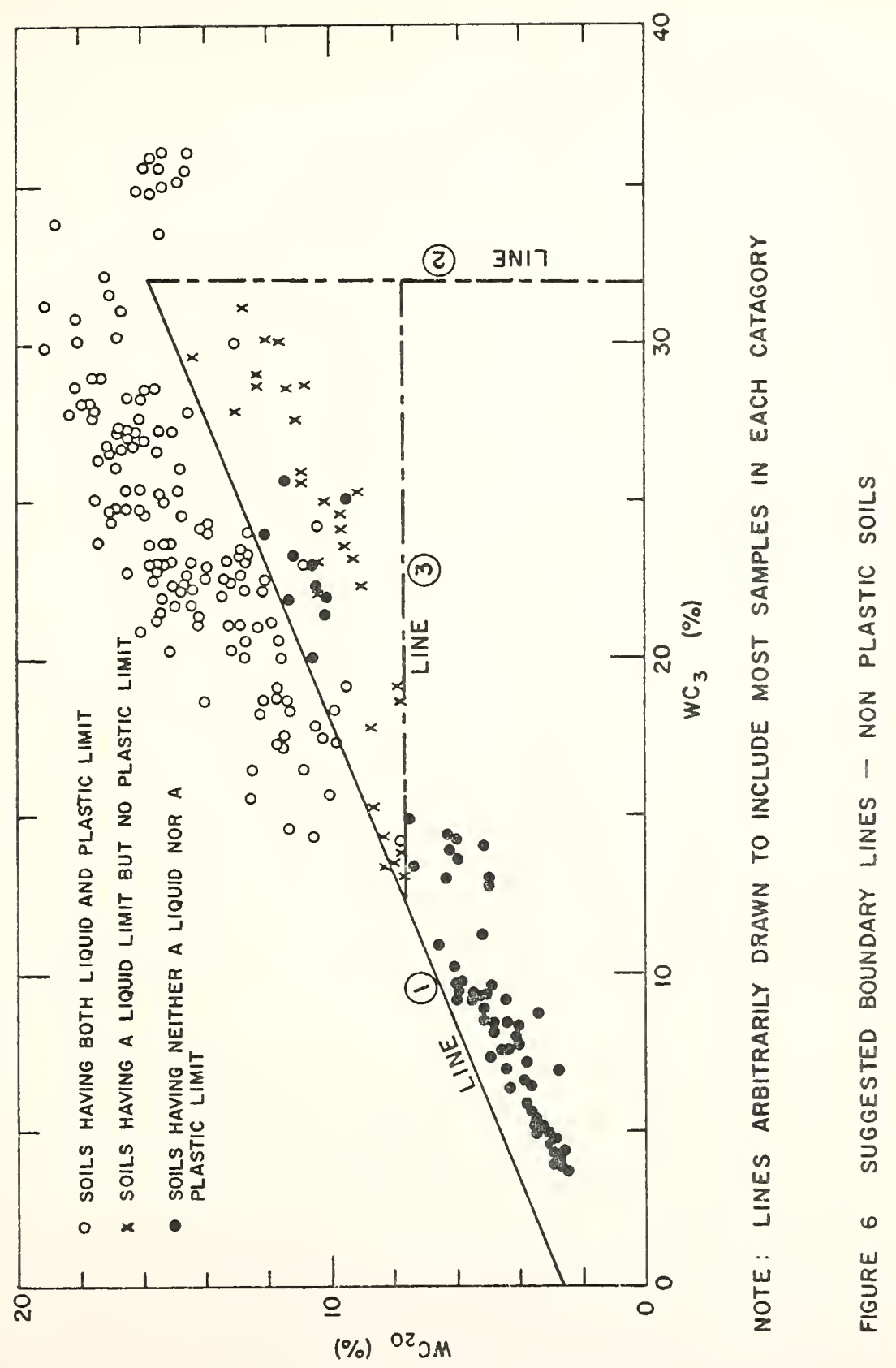


points is that the lower flex point occurs at about 1.5 to 3 psi of pressure and the upper flex point occurs at around 10 to $30 \mathrm{psi}$ of pressure. However, the soils which have only one flex point, such as soil No. 7 may have another flex point above the range of pressure applied.

Some attempts were made to find relationship between soil composition and the shape of the moisture tension curve. The results of this study will be discussed in the next section.

The Relationship Between Soil Composition and Moisture Tension The soil composition shown in Tables 3 and 4 are not totally suitable to specify the properties of the soils, since the classification depends upon the amount of the soil finer than $2 \mathrm{~mm}$, whereas the soil samples used for all tests passed the No. 40 sieve. Table F-l shows the soil compositions based on the sizes No. 40 mesh sieve, $0.05 \mathrm{~mm}$ and $0.005 \mathrm{~mm}$. In the following sections, this classification will be used. For convenience, the fraction passing the No. 40 sieve and retained in the $0.05 \mathrm{~mm}$ will be called "coarse portion", the fraction between $0.05 \mathrm{~mm}$ and $0.005 \mathrm{~mm}$ as "medium portion" and the fraction smaller than $0.005 \mathrm{~mm}$ as "fine portion". They are expressed as percent by weight.

Figure F-1 through Figure F-8 show the relationships between the soil composition and water content by the moisture tension method. From these figures the following may be observed.

1. Coarse portion

$$
\begin{array}{ll}
\text { low } W_{3} & \text { fair correlated (Figure F-l) } \\
\text { low } W_{20} & \text { relatively scattered (Figure F-5) } \\
\text { low }\left(W C_{3}-W C_{20}\right) & \text { relatively scattered (Figure F-7) }
\end{array}
$$


2. Medium portion

$$
\begin{array}{ll}
\text { high } \mathrm{WC}_{3} & \text { very scattered (Figure F-2) } \\
\text { high } \mathrm{WC}_{20} & \text { very scattered (Figure F-6) } \\
\text { high }\left(\mathrm{WC}_{3}-\mathrm{WC}_{20}\right) & \text { very scattered (Figure F-8) }
\end{array}
$$

3. Fine portion

$$
\begin{array}{ll}
\text { high } \mathrm{WC}_{3} & \text { relatively scattered (Figure F-2) } \\
\text { high } \mathrm{WC}_{20} & \text { better correlated (Figure F-4) } \\
\text { high }\left(\mathrm{WC}_{3}-\mathrm{WC}_{20}\right) &
\end{array}
$$

From the above, it can be concluded that sands show low $\mathrm{WC}_{3}$, $\mathrm{WC}_{20}$ and $\left(W_{3}-W_{20}\right)$; clays show high $W_{3}, W C_{20}$ and $\left(W C_{3}-W C_{20}\right)$. The soils whose medium portion is predominant may have a large difference of $\mathrm{WC}_{3}$ and $\mathrm{WC}_{20^{\circ}}$. Silts may belong to this type of soil. (See soil No. 9 in Figure 7.) A small difference in the fine portion causes a larger difference in $W_{3}$ and $W_{20}$ than in the other two portions. This means that the fine portion will have a predominant effect mostly on both $W_{3}$ and $W_{20}$ (Figure $F-8$ ).

The difference between $W_{3}$ and $W_{20}$ is related to the slope of the moisture tension curves. In Figure 9, it is also shown as a distance between $W_{20}$ and a point on the 45 degree line. Silts, in which the medium portion is predominant, plot far below the 45 degree line in a $W_{3}$ vs. $W_{20}$ plot (See Figure 7 and Figure 8 ). Sands plot in the lower left and clays in the upper right. 


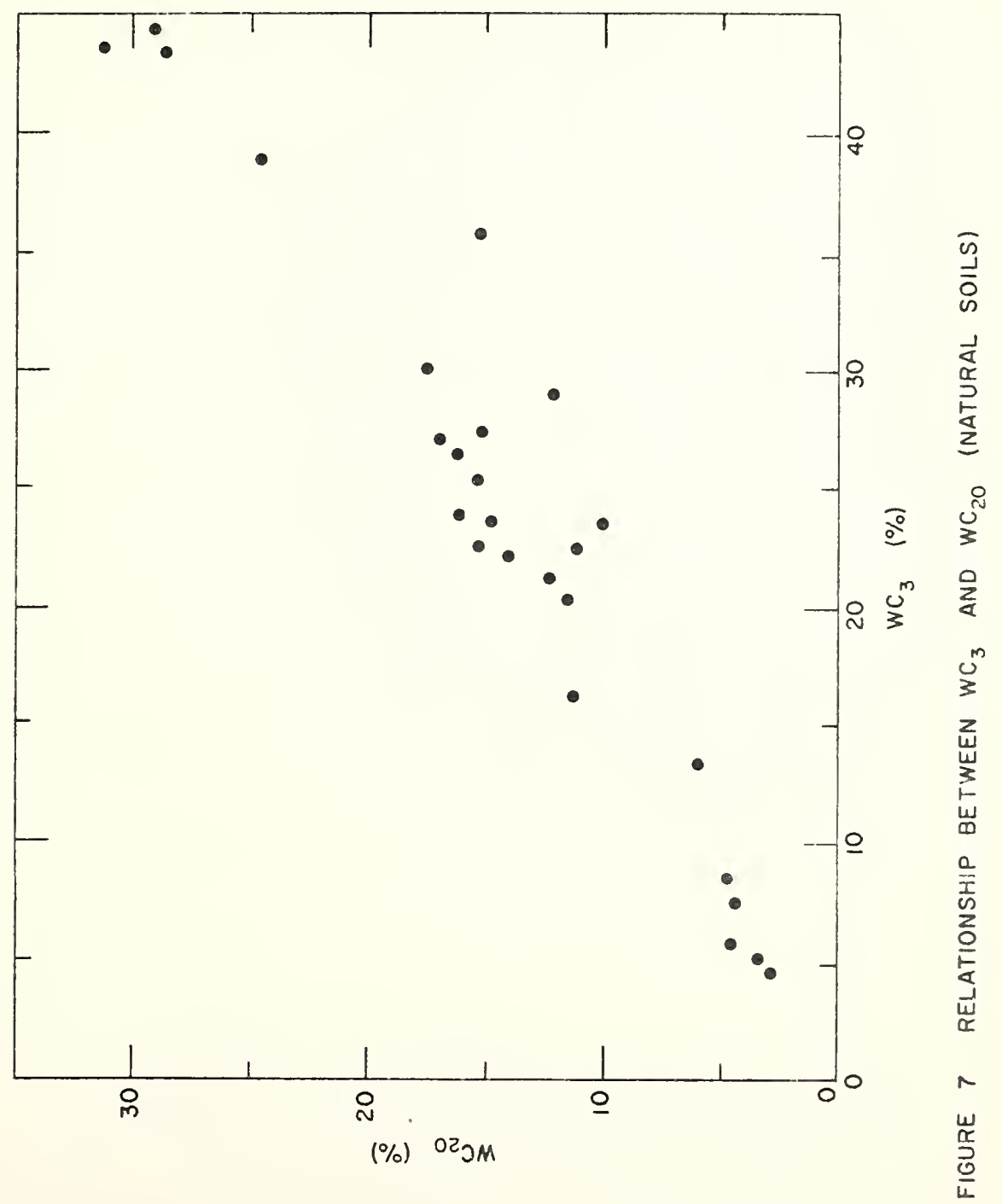




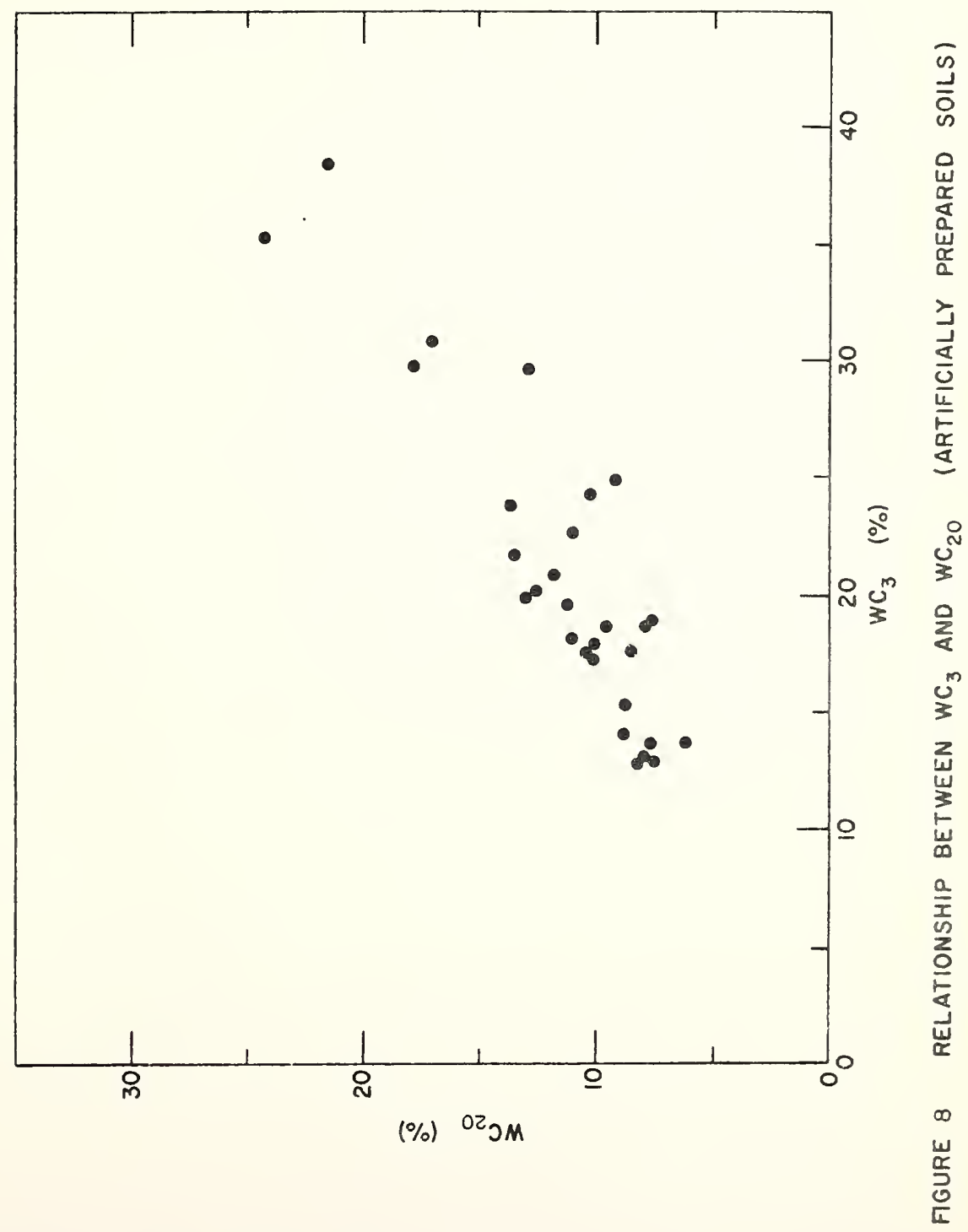




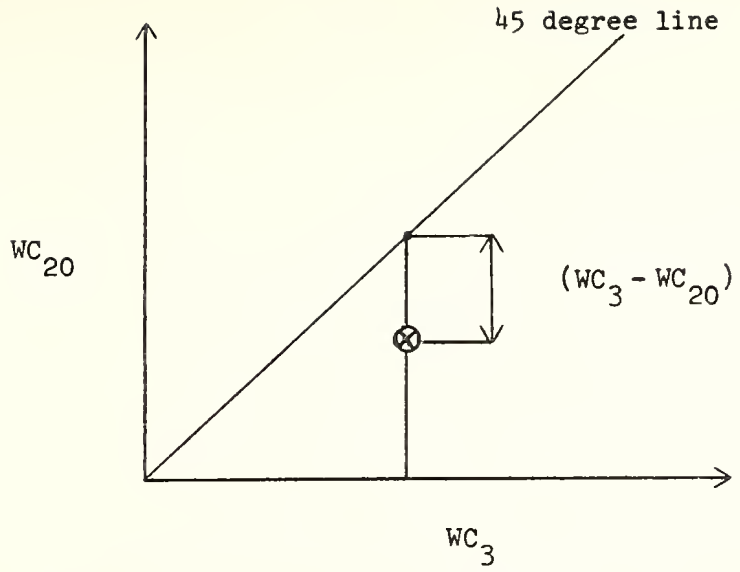

FIGURE 9. RELATIONSHIP BETWEEN WC 3 AND $W_{20}$

These relationships may be useful in determining soil composition and classifying them; thus, it can be seen that the slope of a moisture tension curve may have great importance.

An attempt was made to express the slope in meaningful terms. It appears reasonable to assume that the relationship between log pressure and water content is linear between the range of $3 \mathrm{psi}$ and $20 \mathrm{psi}$ of pressure. Then

$$
\log p=a+b w
$$

where

$$
\begin{aligned}
& \mathrm{p}=\text { pressure (psi) } \\
& \mathrm{w}=\text { water content at equilibrium under the pressure } \mathrm{p}(\%)
\end{aligned}
$$

$\mathrm{WC}_{3}$ is moisture content at 3 psi of pressure and $\mathrm{WC}_{20}$ moisture content at 20 psi; then

$$
\begin{aligned}
& \log 3=a+b W_{3}, \text { and } \\
& \log 20=a+b W_{20}
\end{aligned}
$$

From these equations, the following equations are valid. 


$$
\mathrm{wC}_{20}=\frac{\log 20-\mathrm{a}}{\log 3-\mathrm{a}} \quad \mathrm{WC}_{3}
$$

or

$$
\mathrm{wC}_{20}=\mathrm{WC}_{3}-\frac{1}{\mathrm{~b}} \log \left(\frac{3}{20}\right)
$$

From equation (2), it can be shown that, if a property of a soil can be expressed only by the intercept (coefficient a) of the moisture tension curve, then $W_{20}$ can be predicted from $W_{3}$ thus simplifying, the procedure. The need for further research on the slope of the curve is indicated.

\section{Factors Affecting the Moisture Tension Method}

\section{Equipment and Ceramic Plate}

One of the factors affecting moisture tension results is the magnitude of applied pressure. In this study data were not collected to examine the influence of small variations in pressure on the results; however, it can be seen from the moisture tension curves that water content is influenced more by pressure variations at low pressure than at high pressures. Further, this effect is different for different soils. In case of soil 13 in Figure E-5, equilibrium water content at 1.0 psi pressure was $52.5 \%$ and at about 1.2 psi equilibrium was $50.0 \%$ moisture. Hence, increase in pressure at around 1.0 psi resulted in a $5 \%$ decrease of water content. Variation in the applied pressure was observed and recorded during tests. In the case of 3 psi applied pressure, the maximum difference from the 3 psi applied pressure was 0.2 psi. However, there was generally not this much change in pressure during the tests since careful adjustment of valves and regulators and periodic checks on the system insured consistency of the desired pressure. 


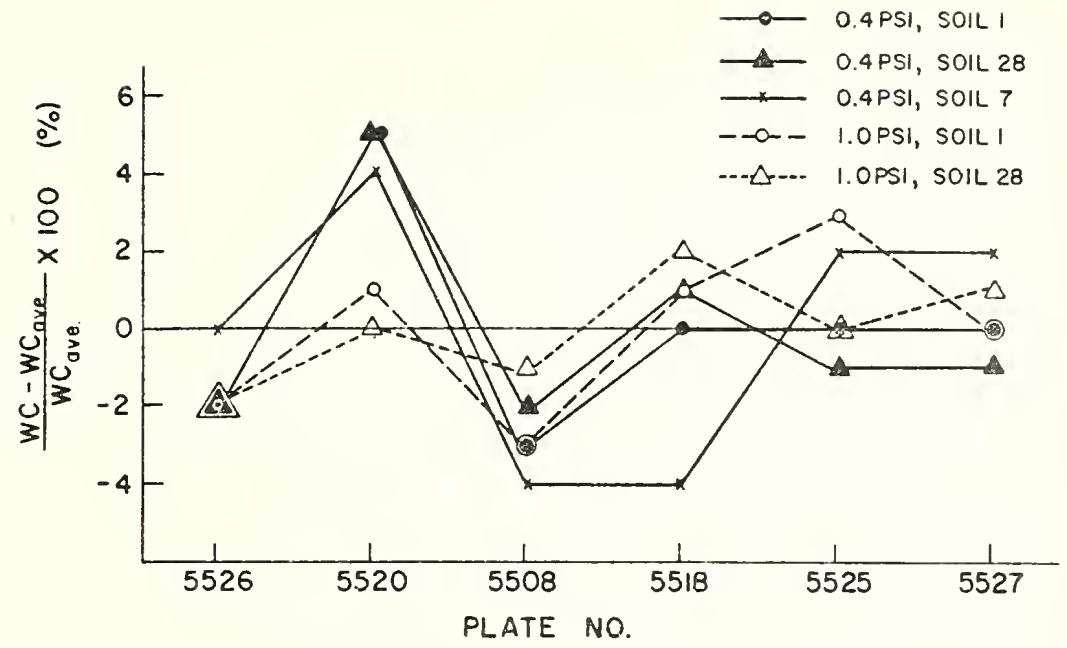

FIGURE 10 WATER CONTENT VARIATION BETWEEN PLATES

(o)

SOLLI

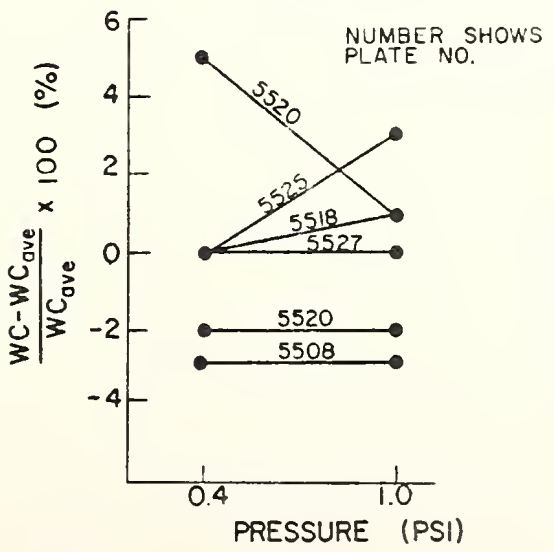

(b)

SOlL 28

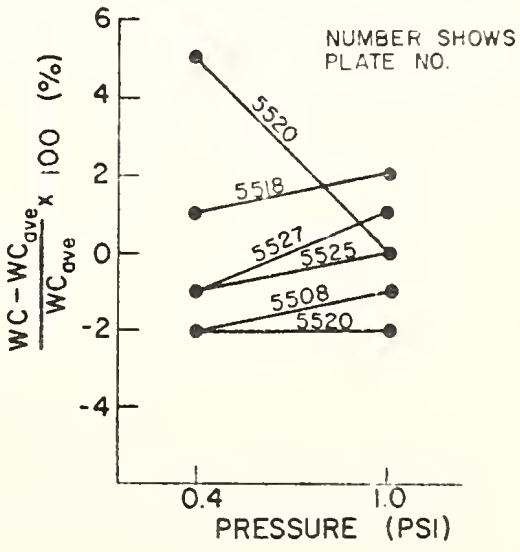

FIGURE II THE CHANGES OF WATER CONTENT DEVIATION BY PRESSURES 
The influence of using different ceramic plates was evaluated by replicating the same soils under the same pressure using different plates. The results are shown in Table A-10 and Figures 10 and 11 . A difference between plates were observed. However, the deviation from the mean value was less than $\pm 5 \%$ for a given water content. In this study the influence of different plates on the results was assumed to be negligible.

\section{Time Factor Study}

The materials used for this study were soil No. 2, No. 3, No. 5 and No. 6. Each of these soils are clays. A total of seven loading periods were used; 1,2, 4, 13 (or 14 or 16), 24, 36 and 48 hours. The intensities of the pressure applied were $1.0,2.0$ and 4.0 psi.

The test method has been described in previous paragraphs. The results are shown in Table $A-11$ and Figure 12 through Figure 15.

In all the figures the abscissa denotes the loading time in log hours; the loading time is the elapsed time during which the pressure is maintained. The ordinates of the graphs represent the moisture content of the soil samples. All these figures show, as expected, that moisture content of a soil by this method is a function of loading time and that it decreases as the length of time is increased. Though the plots are scattered in some cases, it can be said that equilibrium is attained within about 6 to 8 hours after the pressure is applied. However, it may not be said that the elapsed time to reach equilibrium by a higher pressure is always shorter than that by a lower pressure. The results of this study have indicated that a period of 24 hours as used in all the tests in this study is sufficient for attaining equilibrium. 


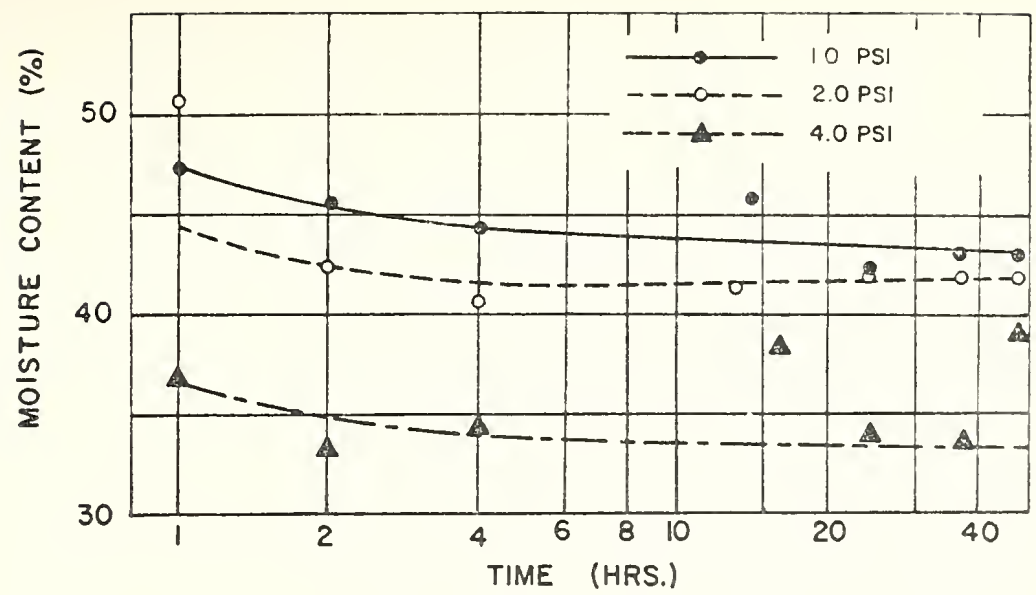

FIGURE 12 EFFECT OF TIME AND PRESSURE ON MOISTURE CONTENT SOIL NO. 2

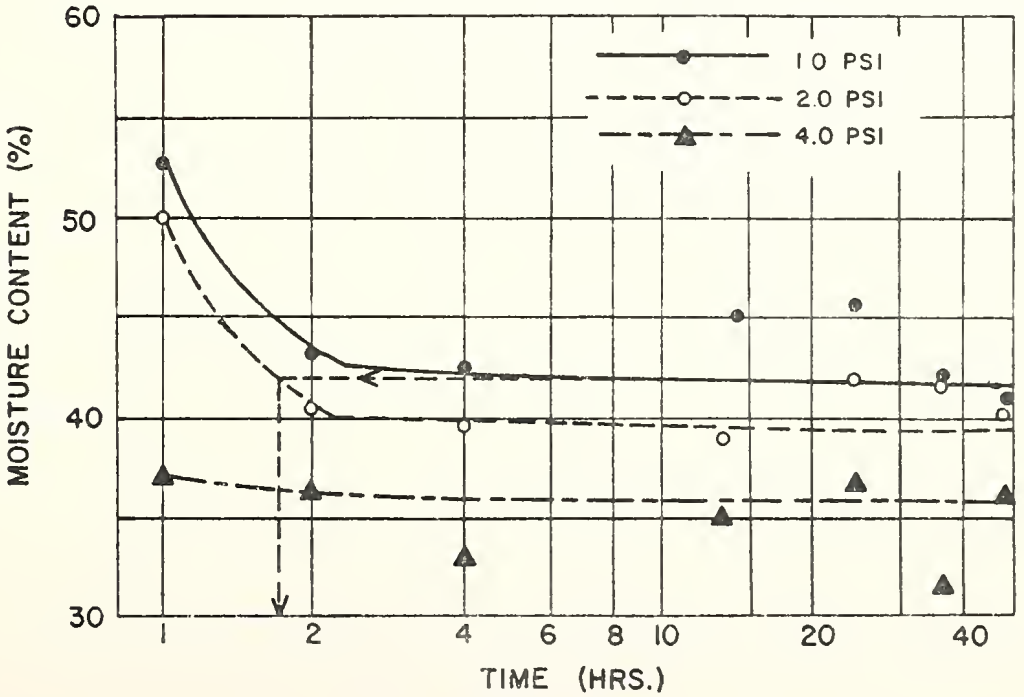

FIGURE I3 EFFECT OF TIME AND PRESSURE ON MOISTURE CONTENT SOIL NO. 3 


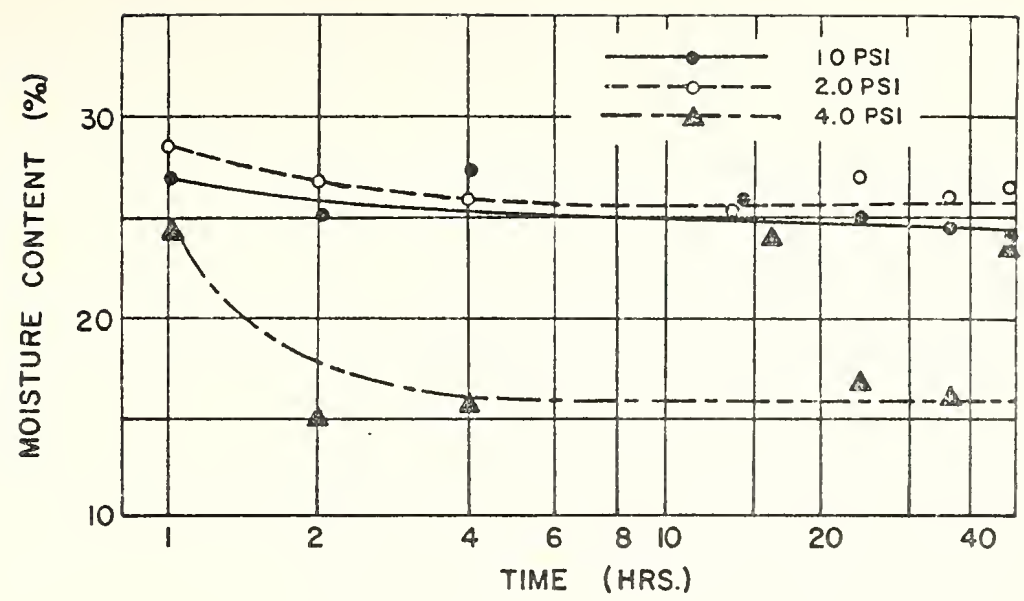

FIGURE 14 EFFECT OF TIME AND PRESSURE ON MOISTURE CONTENT SOIL NO. 5

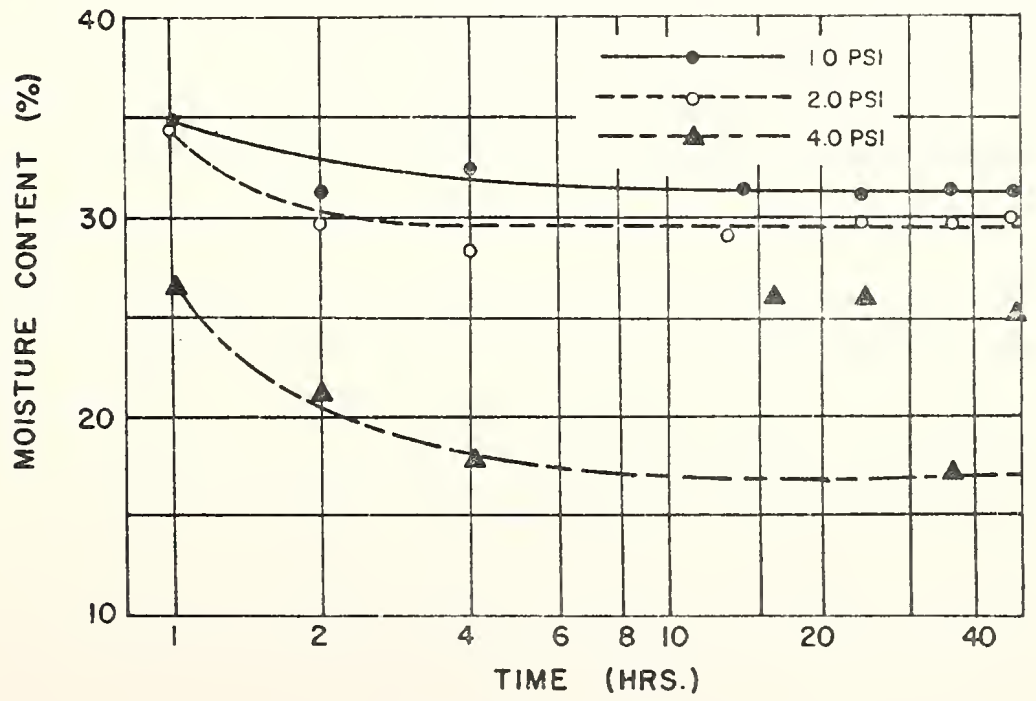

FIGURE I5 EFFECT OF TIME AND PRESSURE ON MOISTURE CONTENT SOIL NO. 6 
In this study the relationships between intensity of pressure, the time for equilibrium and moisture content were investigated further in an effort to make the method faster and thus more economical.

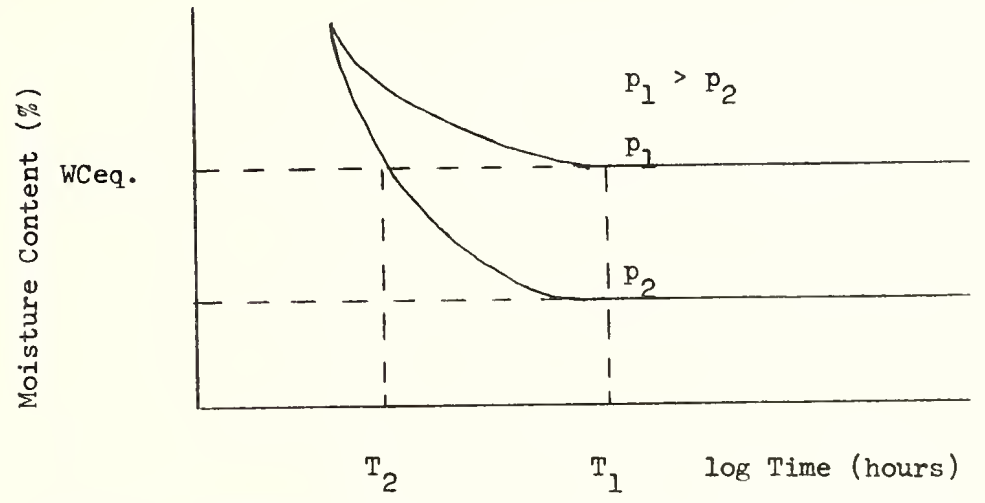

FIGURE 16. EFFECT OF PRESSURE AND LOADING TIME ON EQUILIBRIUM MOISTURE CONTENT.

Figure 16 illustrates the effect of pressure. Assume that T 1 denotes the time necessary to reach the equilibrium water content WCeg under a low pressure $\mathrm{p}_{1}$; a higher pressure $\mathrm{p}_{2}$ would yield the same water content of WCeq. in a shorter time $T_{2}$. If the test results are examined for this purpose, then in Figure 13 the dotted line shows a similar relation as in Figure 16. This means that if the moisture tension test was performed to obtain the equilibrium water content under a pressure of $1.0 \mathrm{psi}$, it would take at least 8 hours. However, using a pressure of $2.0 \mathrm{psi}$ the necessary time for obtaining the same water content would be two hours. If other figures are examined, it can be noted that this was not always true. In other words, $T_{2}$ did not bear the same relation to $\mathrm{T}_{1}$ for all the soils. 
SUMMARY AND RECOMMENDATIONS

The conclusions and recommendations for further study given below are based upon an investigation of one type of soil moisture tension device. In all probability, each type of instrument has its own characteristics and to make the method generally applicable, it would be necessary to calibrate each specific device. The primary purpose of this study was to investigate the factors affecting the method of test and to evaluate the feasibility of using the moisture tension technique for predicting the Atterberg limits of several Indiana soils. Additional work needs to be done to clarify some of the factors which were studied. Nevertheless, the results of this study have pointed out many interesting conclusions and have suggested the feasibility of the method. All conclusions listed below apply specifically to the devices used in this study and to the methods of test imposed in the laboratory.

1. The values of $\left(W C_{20}\right)^{2}$, $\left(W C_{3}\right)^{2}$ and $\left(W C_{3}\right)\left(W C_{20}\right)$, which were obtained from the moisture tension method, using 3 psi and 20 psi of pressure, showed high correlations with the liquid and plastic limits and the plasticity index as shown in Table 12 and Table 13. These correlations were found to be independent of soil textural classification.

2. The relationship between $W_{3}$ and $W_{20}$ in the moisture tension method was found to be dependent upon soil plasticity as shown in Figure 6. 
3. The variances within and among operators in the moisture tension method was found to be very small for both the observed values and the values estimated by using any prediction equations shown.

4. The data indicate that it should be possible to apply the moisture tension test using fust two pressures ( 3 psi and 20 psi) or a soil to estimate its consistency limits regardless of its soil textural classification.

5. The moisture tension method may be a useful tool for estimating grain size composition of soils. The need for further study on this is suggested.

6. Even though there is little chance in this method for operator error, additional attention should be directed to standardization methods of sample preparation.

7. The results of the time factor study suggest it may not be practical to use higher pressures to achieve moisture equilibrium more quickly. 
BIBLIOGRAPHY 
BIBLIOGRAPHY

1. American Society for Testing and Materials, "Standard Method of Test for Liquid Limit of Soil", American Society for Testing and Materials Standards, Part II, Designation, D423-61T, Philadelphia, Pa., 1964.

2. American Society for Testing and Materials, "Standard Method of Test for Plastic Limit and Plasticity Index of Soils", American Society for Testing and Materials Standards, Part II, Designation, D424-59, Philadelphia, Pa., 1964.

3. Atterberg, A., "Uber die physikalische Bodenunter schung und uber die plastiziat der Tone", Internationale Milteilungen fur Bodenkunde, vol. 1, 1911.

4. Baver, L. D., "Soil Physics", 3rd ed., John Wiley \& Sons, Inc., New York, 1956.

5. Cosagrande, A., "Classification and Identification of Soils", Transactions, American Society of Civil Engineers, Vol. 113, 1948, p. 135 .

6. Dawson, R. F., "Investigations of the Liquid Limit Test on Soils, Symposium on Atterberg Limits", American Society for Testing and Materials Special Technical Publication, No. 254, 1959, p. 190-195.

7. Livneh, M., Kinsky, J., and Zaslavsky, D., "Correlation of Suction Curves with the Plasticity Index of Soils", Jourral of Materials, JMLSA, Vol. 5, No. 1, March 1970, p. 209-220.

8. Richards, L. A., "Methods of Measuring Soil Moisture Tension", Soil Science, Vol. 68, 1949.

9. Richards, L. A., "Porous Plate Apparatus for Measuring Moisture Retention and Transmission by Soil", Soil Science, Vol. 66, 1948 , p. 105-110.

10. Richards, L. A., "A Pressure Membrance Extraction Apparatus for Soil Solution", Soil Science, Vol. 51, 1941, p. 377-386.

11. Richards, L. A., and Firemen, M., "Pressure Plate Apparatus for Measuring Moisture Sorption and Transmission by Soils", Soil Science, Vol. 56, 1943, p. 395-404. 
12. Rollins, R. L., and Davidson, D. T., "The Relation Between Soil Moisture Tension and the Consistency Limits of Soils: Methods for Testing Engineering Soils", Iowa Engineering Experiment Station Bulletin No. 192, 1960, p. 210-220.

13. Russell, E. R., and Mickle, J. L., "A Study to Correlate Soil Consistency Limits with Soil Moisture Tensions", Final Report, Project 490-S, Engineering Research Institute, Iowa State University, Ames, Iowa, 1965.

14. Sultan, H. A., "Relation Between Soil Moisture Tension and the Consistency Limits for Utah Soils", University of Utah, Utah, 1961.

15. Sultan, H. A., "Liquid Limit Values by Soil Moisture Tension", Discussion, Hournal of the Soil Mechanies and Foundation Divisions, Vol. 97, No. SM 1, Jan. 1971, p. 272-273.

16. Terzaghi, C., "Determination of the Consistency of Soils by Means of Penetration Tests", Public Roads, Vol. 7, 1926, p. 230-247.

17. Uppal, H. L., "A Scient1fic Explanation of the Plastic Limit of Solls", Journal of Materials, Vol. 1, March, 1966, p. 164. 
APPENDIX A

Test Data 
Table A-l. Summary of Liquid Limit Values

\begin{tabular}{|c|c|c|c|c|c|c|}
\hline & \multicolumn{6}{|c|}{ Liquid Limit (Percent) } \\
\hline $\begin{array}{l}\text { Operator } \\
\text { Soil No. }\end{array}$ & A & B & $\mathrm{C}$ & D & $E$ & $F$ \\
\hline 1 & & & $\begin{array}{l}46.0 \\
46.9 \\
47.6 \\
50.7 \\
56.0 \\
\end{array}$ & $\begin{array}{l}48.4 \\
49.6 \\
50.3 \\
50.6 \\
53.0 \\
\end{array}$ & 51.0 & 48.0 \\
\hline 2 & 43.0 & 38.5 & & & & 47.8 \\
\hline 4 & $\begin{array}{l}27.4 \\
28.3 \\
27.7 \\
26.6 \\
29.3\end{array}$ & $\begin{array}{l}27.8 \\
28.4 \\
28.5 \\
26.7 \\
28.5\end{array}$ & & & 31.1 & 34.8 \\
\hline 5 & $\begin{array}{l}25.5 \\
24.7\end{array}$ & $\begin{array}{l}26.0 \\
24.3\end{array}$ & & & & 24.5 \\
\hline 6 & $\begin{array}{l}28.9 \\
28.6 \\
26.6 \\
26.2 \\
26.8 \\
\end{array}$ & $\begin{array}{l}26.7 \\
27.0 \\
28.5 \\
27.5 \\
25.6 \\
\end{array}$ & $\begin{array}{l}31.3 \\
28.7 \\
31.1 \\
28.4 \\
28.3 \\
\end{array}$ & $\begin{array}{l}26.2 \\
27.5 \\
28.9 \\
27.9 \\
27.6 \\
\end{array}$ & & 32.2 \\
\hline 7 & & 26.3 & & & & 27.7 \\
\hline 8 & & & $\begin{array}{l}28.0 \\
27.4 \\
27.8 \\
28.0 \\
28.2\end{array}$ & $\begin{array}{l}31.7 \\
29.2 \\
29.8 \\
30.4 \\
28.9\end{array}$ & 27.5 & 26.5 \\
\hline 9 & 30.4 & & & & & 30.5 \\
\hline 10 & 21.5 & & & & & 18.7 \\
\hline
\end{tabular}


Table A-l, cont.

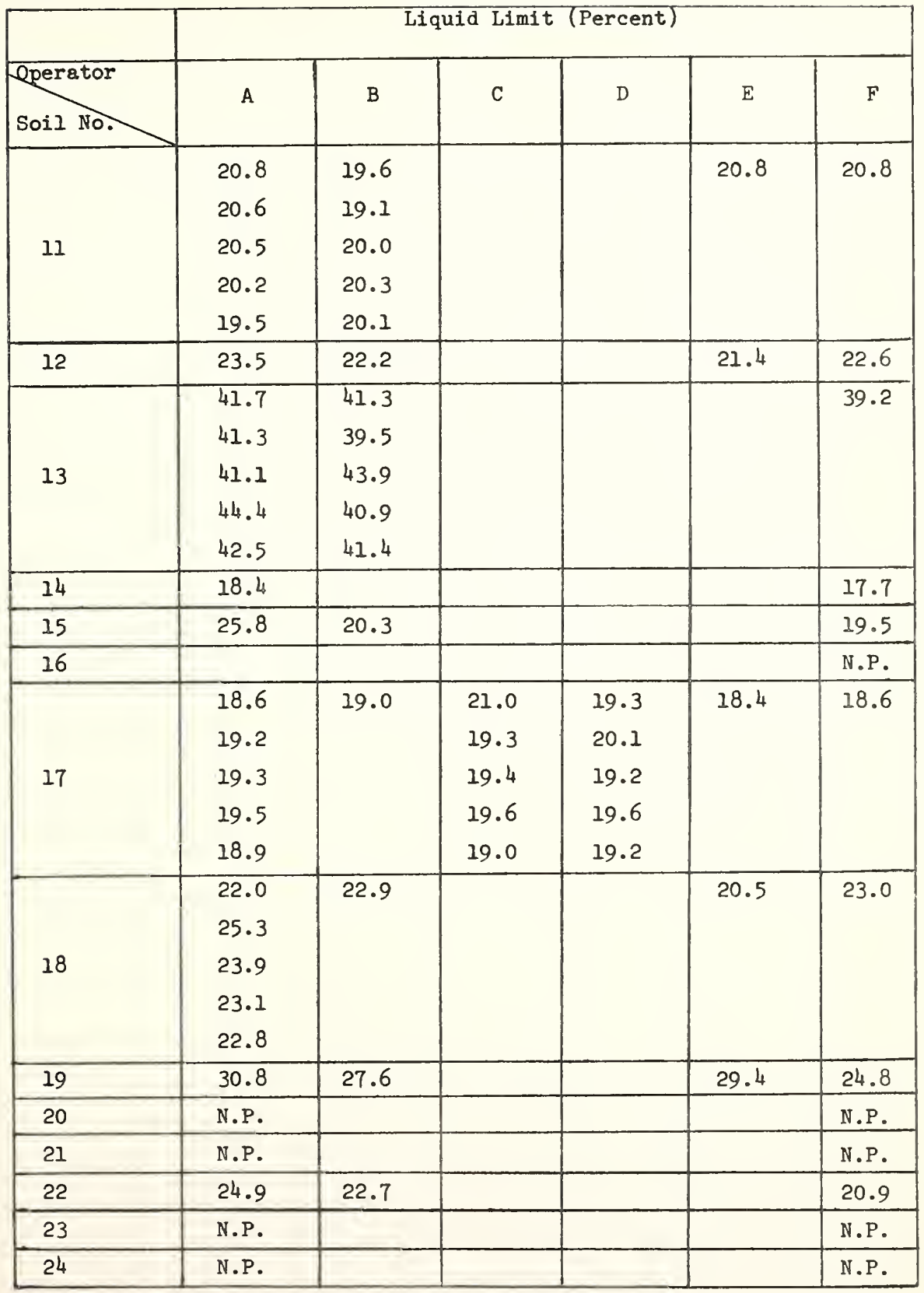


Table A-l, cont.

\begin{tabular}{|c|c|c|c|c|c|c|}
\hline & \multicolumn{6}{|c|}{ Liquid Limit (Percent) } \\
\hline Soil No. & A & B & C & D & $\mathrm{E}$ & $\mathrm{F}$ \\
\hline 25 & N.P. & & & & & N.P. \\
\hline 26 & N.P. & & & & & N.P. \\
\hline 27 & N.P. & & & & & N.P. \\
\hline 28 & & & $\begin{array}{l}65.7 \\
56.8 \\
55.0 \\
54.8 \\
61.0\end{array}$ & $\begin{array}{l}57.6 \\
57.4 \\
56.3 \\
58.2 \\
58.2\end{array}$ & & \\
\hline
\end{tabular}


Table A-2. Sumary of Plastic Limit Values

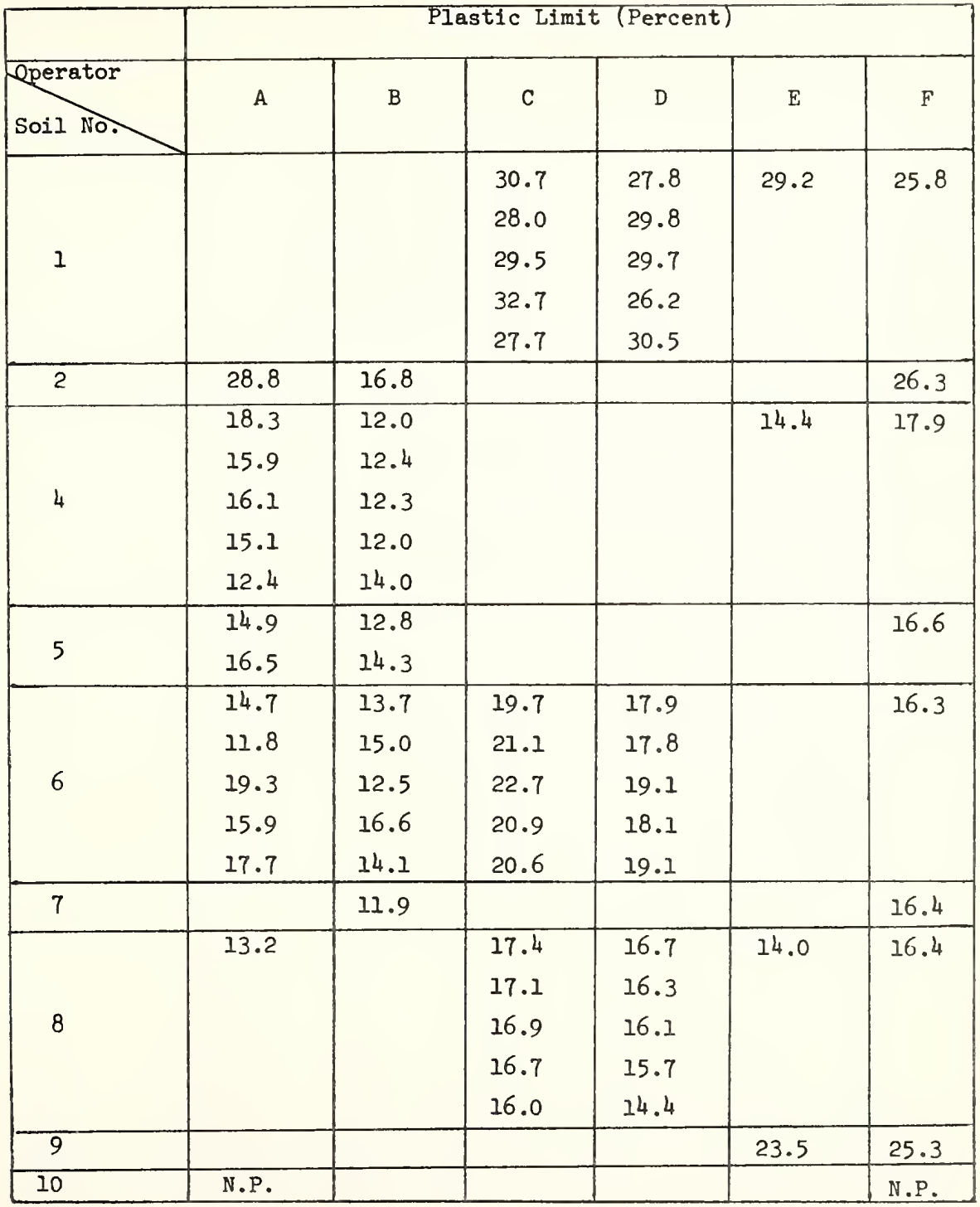


Table A-2, cont.

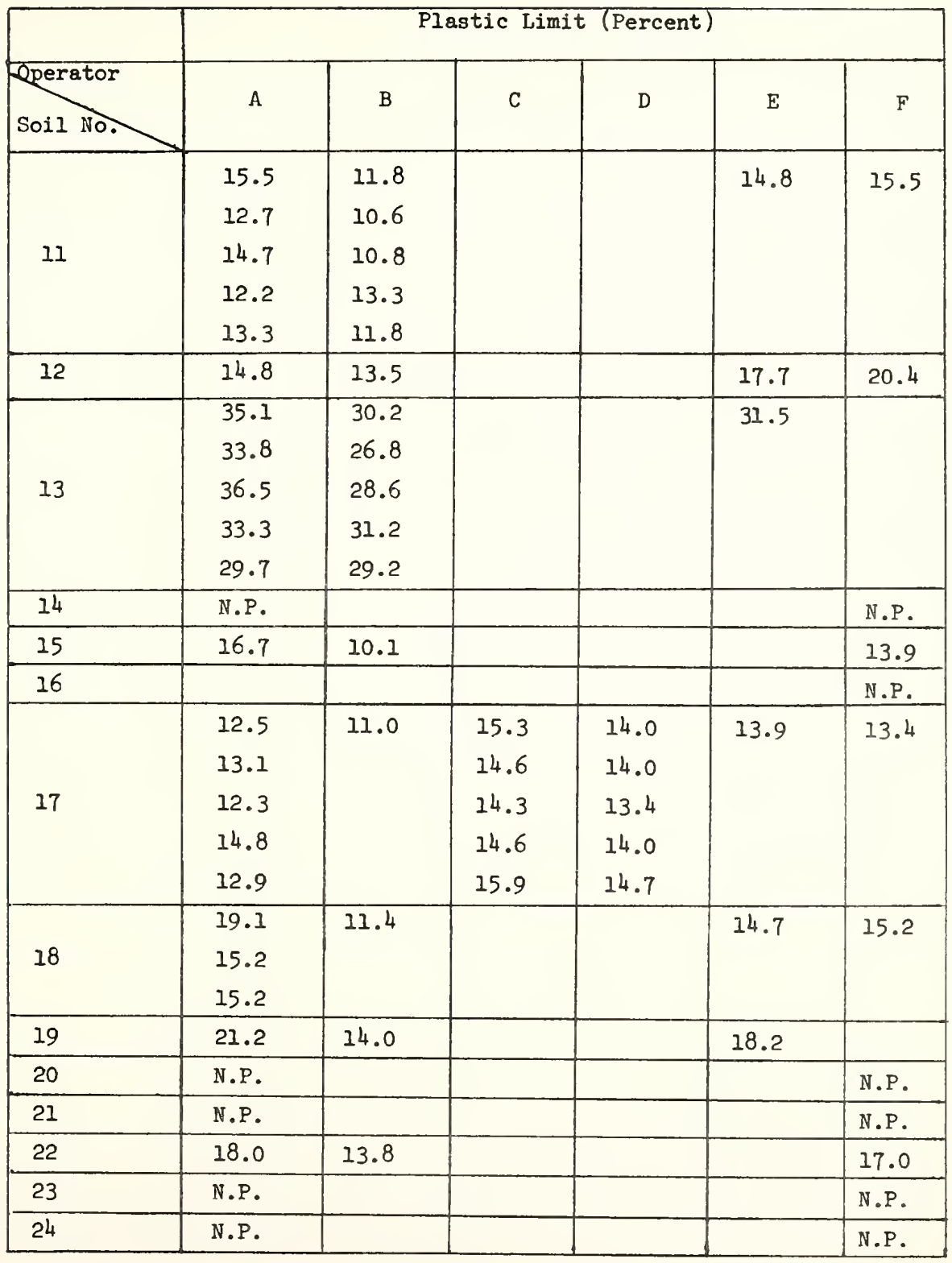


Table A-2, cont.

\begin{tabular}{|c|c|c|c|c|c|c|}
\hline & \multicolumn{6}{|c|}{ Plastic Limit (Percent) } \\
\hline Soil No. & A & B & C & D & $\mathrm{E}$ & $F$ \\
\hline 25 & N.P. & & & & & N.P. \\
\hline 26 & N.P. & & & & & N.P. \\
\hline 27 & N.P. & & & & & N.P. \\
\hline 28 & & & $\begin{array}{l}28.5 \\
27.7 \\
30.4 \\
30.3 \\
29.6\end{array}$ & $\begin{array}{l}29.2 \\
28.7 \\
29.9 \\
27.1 \\
29.0\end{array}$ & & \\
\hline
\end{tabular}


Table A-3. Summary of Test Results for the Artificially Prepared Solls

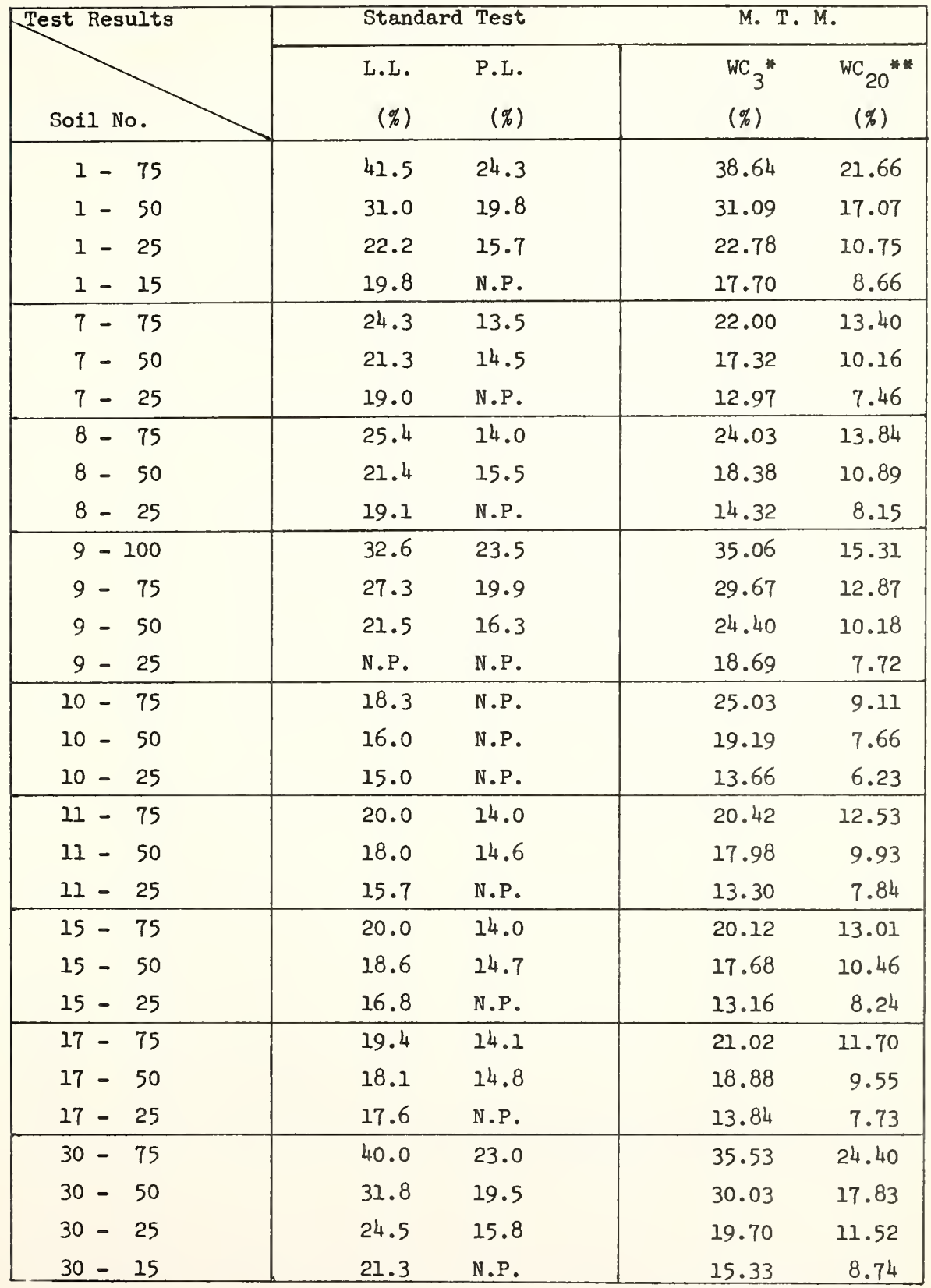

*oisture content e 3 psi using moisture tension device

* Moisture content $e 20$ psi using moisture tension device 
Table A-4.Water Content by Moisture Tension Test

$\mathrm{WC}_{3}$, Operator $\mathrm{H}$

\begin{tabular}{|c|c|c|c|c|c|c|c|}
\hline $\begin{array}{l}\text { Date } \\
\text { Soil No. }\end{array}$ & $\begin{array}{c}\text { Oct } 21 \\
(\%)\end{array}$ & $\begin{array}{c}\text { Oct } 22 \\
(\%)\end{array}$ & $\begin{array}{c}\text { Oct } 26 \\
(\%)\end{array}$ & $\begin{array}{c}\text { Oct } 27 \\
(\%)\end{array}$ & $\begin{array}{c}\text { oct } 28 \\
(\%)\end{array}$ & $\begin{array}{c}\text { Average } \\
(\%)\end{array}$ & $\begin{array}{r}\text { Standard } \\
\text { Deviation } \\
(\%)\end{array}$ \\
\hline 1 & 47.07 & 44.43 & 43.83 & 43.25 & 43.75 & 44.47 & 1.51 \\
\hline 2 & 44.24 & 43.60 & 43.13 & 43.16 & 43.64 & 43.56 & 0.45 \\
\hline 4 & 30.96 & 28.78 & 28.59 & 28.07 & 27.73 & 28.83 & 1.26 \\
\hline 5 & 28.50 & 27.81 & 26.93 & 25.96 & 27.23 & 27.29 & 0.95 \\
\hline 6 & 22.05 & 24.93 & 24.47 & - & - & $(23.82)$ & $(1.55)$ \\
\hline 7 & 28.23 & 28.87 & 25.00 & 24.67 & 27.17 & 26.79 & 1.89 \\
\hline 8 & 28.16 & 27.15 & 25.25 & 25.21 & 24.54 & 26.06 & 1.52 \\
\hline 9 & 35.47 & 36.02 & 34.84 & 33.45 & 34.71 & 34.90 & 0.96 \\
\hline 10 & 29.01 & 30.02 & 27.79 & 27.48 & 28.60 & 28.58 & 1.01 \\
\hline 11 & 22.81 & 22.95 & 21.42 & 21.57 & 21.24 & 22.00 & 0.82 \\
\hline 12 & 17.14 & 22.40 & 22.45 & 20.50 & 18.61 & 20.22 & 2.34 \\
\hline 13 & 38.97 & - & - & - & - & $(38.97)$ & - \\
\hline 14 & 23.05 & 24.96 & 24.63 & 24.85 & 23.35 & 24.17 & 0.90 \\
\hline 15 & 26.60 & 25.31 & 24.82 & 22.77 & 22.85 & 24.47 & 1.65 \\
\hline 16 & 19.87 & 21.34 & 21.81 & 22.93 & 22.09 & 21.61 & 1.13 \\
\hline 17 & 22.21 & 22.52 & 21.25 & 21.71 & 22.22 & 21.98 & 0.50 \\
\hline 18 & 21.60 & 23.19 & 23.88 & 23.38 & 23.33 & 23.08 & 0.87 \\
\hline 19 & 14.62 & 14.33 & 16.35 & 15.64 & 17.06 & 15.60 & 1.15 \\
\hline 20 & 11.20 & 12.98 & 13.40 & 14.27 & 13.56 & 13.08 & 1.15 \\
\hline 21 & 9.14 & 10.19 & 9.69 & 10.94 & 9.71 & 9.93 & 0.67 \\
\hline 22 & 27.11 & 27.60 & 27.04 & 25.27 & 28.19 & 27.04 & 1.09 \\
\hline 23 & 7.53 & 6.89 & 6.25 & 8.94 & 7.50 & 7.42 & 1.00 \\
\hline 24 & 4.42 & 4.25 & 6.85 & 3.95 & 4.42 & 4.78 & 1.17 \\
\hline 26 & 5.84 & 5.13 & 4.92 & 4.85 & 4.84 & 5.12 & 0.42 \\
\hline 27 & 8.55 & 8.36 & 8.00 & 8.36 & 8.63 & 8.38 & 0.24 \\
\hline 28 & 42.70 & 42.42 & 41.38 & 42.29 & 43.36 & 42.43 & 0.72 \\
\hline \multicolumn{7}{|c|}{ Average Standard Deviation } & 1.08 \\
\hline
\end{tabular}


Table A-5. Water Content by Moisture Tension Test

$\mathrm{WC}_{20}$, Operator $\mathrm{H}$

\begin{tabular}{|c|c|c|c|c|c|c|c|}
\hline Soil No. & $\begin{array}{c}\text { Oct } 21 \\
(\%)\end{array}$ & $\begin{array}{c}\text { Oct } 22 \\
(\%)\end{array}$ & $\begin{array}{c}\text { Oct } 26 \\
(\%)\end{array}$ & $\begin{array}{c}\text { Oct } 27 \\
(\%)\end{array}$ & $\begin{array}{c}\text { Oct } 28 \\
(\%)\end{array}$ & $\begin{array}{c}\text { Average } \\
(\%)\end{array}$ & $\begin{array}{l}\text { Standard } \\
\text { Deviation } \\
(\%)\end{array}$ \\
\hline 1 & 28.89 & 28.89 & 32.66 & 29.72 & 30.64 & 30.16 & 1.57 \\
\hline 2 & 28.84 & 27.03 & 29.88 & 28.25 & 27.72 & 28.54 & 1.16 \\
\hline 4 & 16.64 & 17.62 & 18.12 & 17.66 & 17.54 & 17.52 & 0.54 \\
\hline 5 & 15.47 & 14.51 & 15.87 & 14.74 & 15.38 & 15.19 & 0.56 \\
\hline 6 & 14.72 & 15.27 & 15.86 & - & - & $(15.28)$ & $(0.57)$ \\
\hline 7 & 16.79 & 17.33 & 17.54 & 16.04 & 16.67 & 16.87 & 0.59 \\
\hline 8 & 15.96 & 16.09 & 16.03 & 15.42 & 15.93 & 15.89 & 0.27 \\
\hline 9 & 15.93 & 15.25 & 16.05 & 15.40 & 15.70 & 15.67 & 0.34 \\
\hline 10 & 12.23 & 11.63 & 12.88 & 10.97 & 10.74 & 11.69 & 0.88 \\
\hline 11 & 15.37 & 14.96 & 15.32 & 14.87 & 15.48 & 15.20 & 0.27 \\
\hline 12 & 11.38 & 11.99 & 13.30 & 11.60 & 11.27 & 11.91 & 0.83 \\
\hline 13 & 24.73 & - & - & - & - & $(24.73)$ & - \\
\hline 14 & 9.34 & 9.46 & 9.64 & 10.00 & 9.52 & 9.59 & 0.25 \\
\hline 15 & 16.14 & 16.38 & 16.83 & 15.51 & 15.28 & 16.03 & 0.63 \\
\hline 16 & 10.50 & 10.08 & 11.27 & 10.47 & 10.39 & 10.54 & 0.44 \\
\hline 17 & 14.56 & 13.90 & 14.24 & 14.38 & 14.35 & 14.29 & 0.24 \\
\hline 18 & 12.11 & 12.81 & 12.62 & 12.79 & 12.78 & 12.62 & 0.30 \\
\hline 19 & 11.27 & 10.48 & 12.38 & 10.01 & 11.52 & 11.13 & 0.92 \\
\hline 20 & 5.32 & 6.28 & 7.28 & 6.21 & 5.91 & 6.20 & 0.71 \\
\hline 21 & 5.97 & 6.11 & 5.87 & 6.59 & 5.89 & 6.09 & 0.30 \\
\hline 22 & 15.00 & 15.96 & 16.40 & 14.82 & 16.36 & 15.71 & 0.75 \\
\hline 23 & 4.41 & 4.27 & 4.33 & 5.08 & 4.32 & 4.48 & 0.34 \\
\hline 24 & 2.89 & 2.73 & 2.78 & 2.76 & 2.90 & 2.81 & 0.08 \\
\hline 26 & 3.76 & 3.53 & 3.47 & 3.07 & 3.00 & 3.37 & 0.32 \\
\hline 27 & 5.11 & 5.07 & 4.08 & 4.96 & 5.06 & 4.86 & 0.44 \\
\hline 28 & 31.82 & 29.76 & 32.09 & 30.47 & 30.63 & 30.95 & 0.98 \\
\hline
\end{tabular}


Table A-6. Water Content by Molsture Tension Test

$\mathrm{WC}_{3}$, Operator I

\begin{tabular}{|c|c|c|c|c|c|}
\hline Soil No & $\begin{array}{c}\text { Dec } 18 \\
(\%)\end{array}$ & $\begin{array}{c}\text { Dec } 19 \\
(\%)\end{array}$ & $\begin{array}{c}\text { Dec } 20 \\
(\%) \\
\end{array}$ & $\begin{array}{c}\text { Average } \\
(\%) \\
\end{array}$ & $\begin{array}{l}\text { Standard } \\
\text { Deviation } \\
(\%)\end{array}$ \\
\hline 1 & 43.03 & 46.06 & 43.69 & 44.26 & 1.59 \\
\hline 4 & 30.80 & 33.70 & 31.19 & 31.90 & 1.57 \\
\hline 7 & 27.83 & 27.77 & 26.08 & 27.23 & 0.99 \\
\hline 8 & 26.65 & 26.57 & 26.30 & 26.51 & 0.18 \\
\hline 9 & 35.80 & 39.65 & 35.47 & 36.97 & 2.32 \\
\hline 10 & 29.49 & 31.11 & 28.99 & 29.86 & 1.11 \\
\hline 11 & 21.88 & 24.32 & 22.51 & 22.90 & 1.27 \\
\hline 12 & 20.90 & 22.95 & 22.61 & 22.15 & 1.10 \\
\hline 14 & 22.97 & 25.60 & 25.75 & 24.77 & 1.56 \\
\hline 15 & 23.66 & 24.82 & 24.62 & 24.37 & 0.62 \\
\hline 16 & 22.82 & 21.86 & 25.61 & 23.43 & 1.95 \\
\hline 17 & 20.95 & 23.57 & 23.01 & 22.51 & 1.38 \\
\hline 18 & 21.11 & 19.26 & 22.23 & 20.87 & 1.50 \\
\hline 19 & 16.98 & 16.26 & 15.49 & 16.24 & 0.75 \\
\hline 20 & 14.81 & 13.93 & 14.17 & 14.30 & 0.45 \\
\hline 21 & 9.07 & 9.34 & 9.36 & 9.26 & 0.16 \\
\hline 22 & 24.99 & 25.61 & 25.31 & $25 \cdot 30$ & 0.31 \\
\hline 23 & 7.33 & 7.12 & 8.13 & 7.53 & 0.53 \\
\hline 24 & 3.68 & 4.27 & 5.14 & 4.36 & 0.73 \\
\hline 26 & 6.44 & 4.86 & 5.54 & 5.61 & 0.79 \\
\hline 27 & 9.25 & 7.71 & 9.25 & 8.74 & 0.89 \\
\hline 28 & 45.74 & 45.62 & 43.27 & 44.88 & 1.39 \\
\hline & & \multicolumn{3}{|c|}{ Average Standard Deviation } & 1.05 \\
\hline
\end{tabular}


Table A-7. Water Content by Moisture Tension Test

$\mathrm{WC}_{20}$, Operator I

\begin{tabular}{|c|c|c|c|c|c|}
\hline Soil No. & $\begin{array}{c}\text { Dec } 18 \\
(\%)\end{array}$ & $\begin{array}{c}\text { Dec } 19 \\
(\%)\end{array}$ & $\begin{array}{c}\text { Dec } 20 \\
(\%) \\
\end{array}$ & $\begin{array}{c}\text { Average } \\
(\%) \\
\end{array}$ & $\begin{array}{c}\text { Standard } \\
\text { Deviation } \\
(\%)\end{array}$ \\
\hline 1 & 28.02 & 30.07 & 29.92 & 29.34 & 1.14 \\
\hline 4 & 18.14 & 18.73 & 19.04 & 18.64 & 0.46 \\
\hline 7 & 18.26 & 17.46 & 16.68 & 17.47 & 0.79 \\
\hline 8 & 16.24 & 16.57 & 17.25 & 16.69 & 0.52 \\
\hline 9 & 15.71 & 15.56 & 15.36 & 15.54 & 0.18 \\
\hline 10 & 14.34 & 12.67 & 12.23 & 13.08 & 1.11 \\
\hline 11 & 15.25 & 16.95 & 15.57 & 15.92 & 0.90 \\
\hline 12 & 12.28 & 13.20 & 12.76 & 12.75 & 0.46 \\
\hline 14 & 10.33 & 10.83 & 10.76 & 10.64 & 0.27 \\
\hline 15 & 17.36 & 16.49 & 17.02 & 16.96 & 0.44 \\
\hline 16 & 13.85 & 10.15 & 11.38 & 11.79 & 1.88 \\
\hline 17 & 14.17 & 15.03 & 14.29 & 14.50 & 0.47 \\
\hline 18 & 11.71 & 10.76 & 12.91 & 11.79 & 1.08 \\
\hline 19 & 11.51 & 10.79 & 12.47 & 11.59 & 0.84 \\
\hline 20 & 7.52 & 6.20 & 6.05 & 6.59 & 0.81 \\
\hline 21 & 5.45 & 5.08 & 5.85 & 5.46 & 0.39 \\
\hline 22 & 13.18 & 13.94 & 14.98 & 14.03 & 0.90 \\
\hline 23 & 4.89 & 3.82 & 4.86 & 4.52 & 0.61 \\
\hline 24 & 2.51 & 2.82 & 3.34 & 2.89 & 0.42 \\
\hline 26 & 3.73 & 3.29 & 3.59 & 3.54 & 0.22 \\
\hline 27 & 5.11 & 4.04 & 5.40 & 4.85 & 0.72 \\
\hline 28 & 32.66 & 31.91 & 32.20 & 32.26 & 0.38 \\
\hline \multicolumn{5}{|c|}{ Average Standard } & 0.68 \\
\hline
\end{tabular}


Table A-\& Water Content by Moisture Tension Test $\mathrm{WC}_{3}$, Operator $\mathrm{J}$

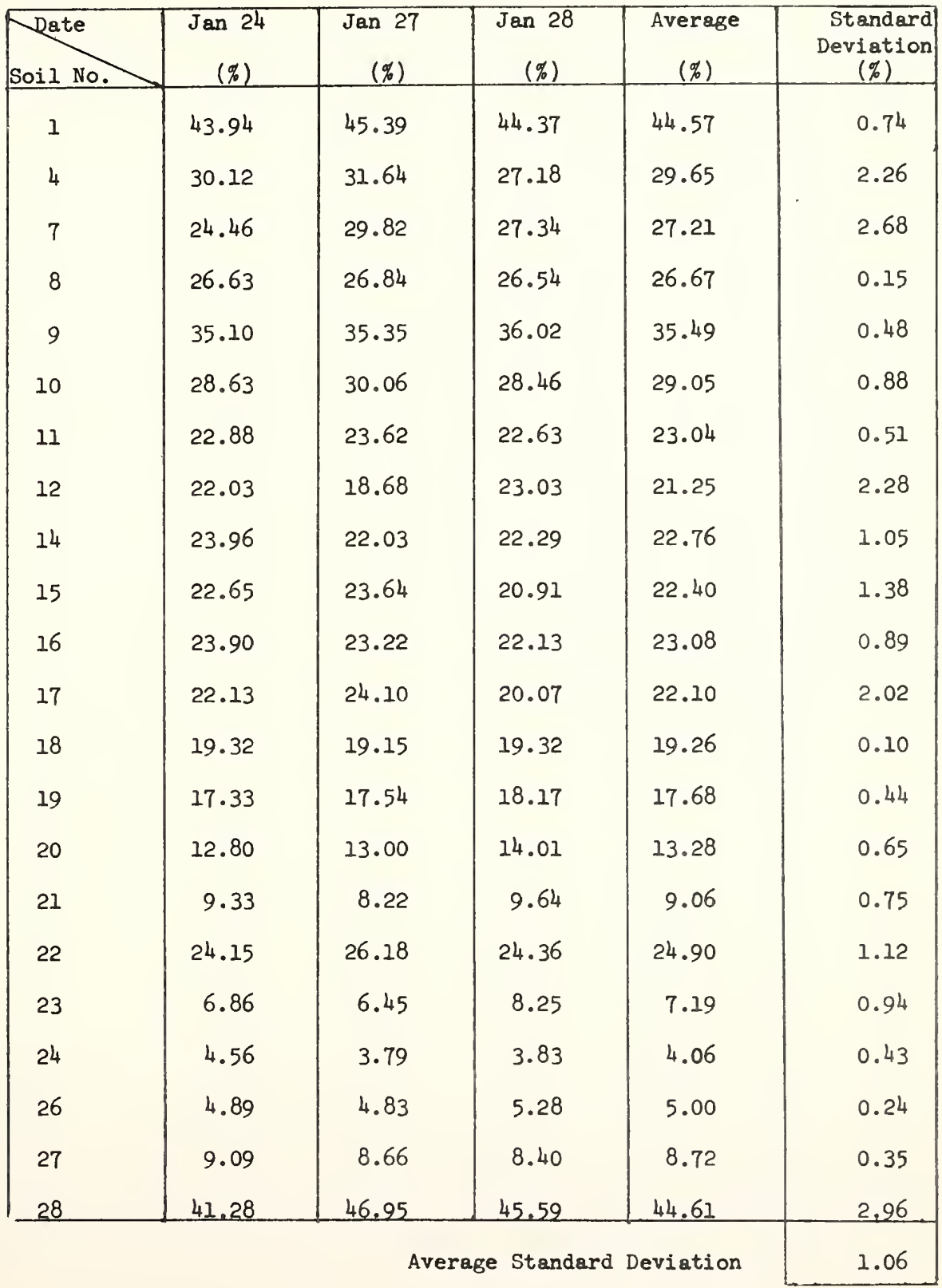


Table A-9. Water Content by Moisture Tension Test

${ }^{W} C_{20}$, Operator $\mathrm{J}$

\begin{tabular}{|c|c|c|c|c|c|}
\hline Soil No. & $\begin{array}{c}\operatorname{Jan} 24 \\
(\%)\end{array}$ & $\begin{array}{c}\operatorname{Jan} 27 \\
(\%)\end{array}$ & $\begin{array}{c}\operatorname{Jan} 28 \\
(\%)\end{array}$ & $\begin{array}{c}\text { Average } \\
(\%)\end{array}$ & $\begin{array}{c}\text { Standard } \\
\text { Deviation } \\
(\%)\end{array}$ \\
\hline 1 & 26.89 & 26.53 & 28.11 & 27.18 & 0.83 \\
\hline 4 & 16.83 & 16.91 & 16.29 & 16.68 & 0.34 \\
\hline 7 & 14.69 & 19.03 & 16.66 & 16.79 & 2.17 \\
\hline 8 & 17.06 & 17.11 & 15.51 & 16.56 & 0.91 \\
\hline 9 & 14.79 & 14.64 & 14.51 & 14.65 & 0.14 \\
\hline 10 & 12.17 & 12.85 & 11.31 & 12.11 & 0.77 \\
\hline 11 & 15.66 & 15.11 & 14.48 & 15.08 & 0.59 \\
\hline 12 & 12.82 & 11.74 & 12.61 & 12.39 & 0.57 \\
\hline 14 & 9.56 & 10.32 & 9.02 & 9.63 & 0.65 \\
\hline 15 & 16.37 & 15.72 & 16.00 & 16.03 & 0.33 \\
\hline 16 & 12.04 & 11.09 & 11.86 & 11.66 & 0.50 \\
\hline 17 & 12.74 & 14.12 & 12.72 & 13.19 & 0.80 \\
\hline 18 & 11.37 & 11.77 & 10.82 & 11.32 & 0.48 \\
\hline 19 & 11.73 & 11.39 & 12.19 & 11.77 & 0.40 \\
\hline 20 & 4.99 & 5.00 & 5.14 & 5.04 & 0.08 \\
\hline 21 & 5.30 & 4.87 & 4.86 & 5.01 & 0.25 \\
\hline 22 & 13.79 & 15.10 & 13.07 & 13.99 & 1.03 \\
\hline 23 & 4.31 & 3.80 & 3.98 & 4.03 & 0.26 \\
\hline 24 & 2.87 & 2.67 & 2.66 & 2.73 & 0.12 \\
\hline 26 & 5.43 & 3.07 & 3.48 & 3.99 & 1.26 \\
\hline 27 & 4.42 & 3.43 & 4.38 & 4.08 & 0.56 \\
\hline 28 & 30.24 & 32.43 & 33.03 & 31.90 & 1.47 \\
\hline
\end{tabular}


Table A-10. Effect of Plate on Test Results

\begin{tabular}{|c|c|c|c|c|c|c|c|c|}
\hline Pressure & Soil No. & 5526 & 5520 & 5508 & 5518 & 5525 & 5527 & Average \\
\hline \multirow{12}{*}{$\begin{array}{l}0.4 \\
\text { psi }\end{array}$} & \multirow{4}{*}{$-\overline{\text { Ave }}$} & 56.31 & 60.70 & 55.40 & 56.97 & 57.78 & 57.45 & \multirow{4}{*}{57.57} \\
\hline & & 56.64 & 60.45 & 55.90 & 57.98 & 57.36 & 57.82 & \\
\hline & & 56.08 & 60.66 & 56.05 & 56.97 & 57.47 & 58.19 & \\
\hline & & 56.34 & 60.60 & 55.79 & 57.31 & 57.54 & 57.82 & \\
\hline & \multirow{3}{*}{28} & 57.40 & 59.79 & 56.64 & 57.63 & 56.97 & 57.13 & \multirow{4}{*}{$-\overline{57.00}$} \\
\hline & & 55.64 & 59.92 & 56.47 & 57.08 & 56.20 & 55.77 & \\
\hline & & $\underline{54} . \underline{57}$ & 59.05 & 55.19 & 57.18 & 56.32 & 56.97 & \\
\hline & Ave & 55.87 & 59.59 & 56.10 & 57.30 & 56.50 & 56.62 & \\
\hline & \multirow{4}{*}{$\begin{array}{c}7 \\
\text { Ave }\end{array}$} & 33.85 & 35.23 & 31.71 & 31.29 & 34.22 & 33.68 & \multirow{4}{*}{$-\overline{33.84}$} \\
\hline & & 33.64 & 36.03 & 31.48 & 32.21 & 34.94 & 35.18 & \\
\hline & & 33.87 & 34.29 & 34.49 & 33.46 & 34.46 & 35.16 & \\
\hline & & 33.79 & 35.18 & 32.56 & 32.32 & 34.53 & 34.67 & \\
\hline \multirow{8}{*}{1.0} & \multirow{4}{*}{$\begin{array}{c}1 \\
-1 \\
\text { Ave }\end{array}$} & 54.02 & 56.10 & 53.42 & 55.70 & 56.51 & 55.39 & \multirow{4}{*}{$\overline{5}-\overline{2} 3$} \\
\hline & & 54.40 & 55.65 & 53.62 & 55.74 & 56.90 & 55.32 & \\
\hline & & 54.40 & 55.86 & 53.97 & $55.7 \underline{5}$ & 56.52 & 54.93 & \\
\hline & & 54.27 & 55.87 & 53.67 & 55.73 & 56.64 & 55.21 & \\
\hline & \multirow{3}{*}{28} & 52.17 & 53.75 & 52.69 & 54.74 & 52.78 & 54.24 & \multirow{4}{*}{$\overline{53.55}$} \\
\hline & & 52.38 & 53.87 & 53.09 & 54.01 & 53.02 & 54.37 & \\
\hline & & $\underline{52.15}$ & 52.86 & 53.82 & 54.81 & 54.99 & 54.14 & \\
\hline & Ave & 52.23 & 53.49 & 53.20 & 54.52 & 53.60 & 54.25 & \\
\hline \multirow{4}{*}{3.0} & \multirow{4}{*}{8} & \multirow{4}{*}{--} & \multirow{4}{*}{-} & \multirow{4}{*}{--} & 24.36 & 25.31 & 26.20 & \multirow{4}{*}{$\overline{25.52}$} \\
\hline & & & & & 24.44 & 25.38 & 26.25 & \\
\hline & & & & & 24.55 & 25.66 & 27.55 & \\
\hline & & & & & 24.45 & 25.45 & 26.67 & \\
\hline \multirow{4}{*}{$\begin{array}{l}4.0 \\
\text { psi }\end{array}$} & \multirow{4}{*}{8} & 24.27 & 23.56 & 24.19 & \multirow{4}{*}{--} & \multirow{4}{*}{-} & \multirow{4}{*}{--} & \multirow{4}{*}{$\overline{24.27}$} \\
\hline & & 24.39 & 24.01 & 24.35 & & & & \\
\hline & & 25.03 & 24.21 & 24.39 & & & & \\
\hline & & 24.56 & 23.93 & 24.31 & & & & \\
\hline
\end{tabular}


Table A-11. Effect of Time and Pressure on Water Content

(a) Soil 2

\begin{tabular}{|c|c|c|c|c|c|c|c|}
\hline $\begin{array}{l}\text { Time (hr) } \\
\text { Pressure (psi) }\end{array}$ & 1 & 2 & 4 & $13,14,16^{*}$ & 24 & 36 & 48 \\
\hline 1.0 & .79 & 45.08 & 44.16 & 8 & 41.17 & 42.87 & 42.86 \\
\hline psi & 47.83 & 46.35 & 44.79 & 46.11 & 43.15 & 43.19 & 43.20 \\
\hline Ave. & 47.31 & 45.72 & 44.48 & 45.90 & 42.16 & $\overline{43.03}$ & 43.03 \\
\hline 2.0 & 45.38 & 42.05 & 40.00 & 41.59 & 42.05 & 40.89 & 41.84 \\
\hline psi & 56.10 & 42.94 & 41.39 & & 42.21 & 41.27 & 41.89 \\
\hline Ave. & 50.74 & 42.50 & $\overline{40.70}$ & $\overline{41.59}$ & $\overline{42.13}$ & 41.09 & 41.87 \\
\hline 4.0 & 36.57 & 33.04 & 33.99 & 38.51 & 33.82 & 33.48 & 38.31 \\
\hline psi & 37.03 & 33.35 & 34.49 & 38.57 & 33.97 & 33.52 & 39.3 \\
\hline Ave. & $\overline{36} . \overline{80}$ & 33.20 & $3 \overline{4} \cdot 2 \overline{4}$ & $3 \overline{8} .5 \overline{4}$ & 33.90 & $\overline{33} . \overline{50}$ & 38.82 \\
\hline
\end{tabular}

*14 hrs for $1.0 \mathrm{psi}, 13 \mathrm{hrs}$ for $2.0 \mathrm{psi}$ and $16 \mathrm{hrs}$ for $4.0 \mathrm{psi}$

(b) Soil 3

\begin{tabular}{|c|c|c|c|c|c|c|c|}
\hline $\begin{array}{l}\text { Time (hr) } \\
\text { Pressure (psi) }\end{array}$ & 1 & 2 & 4 & $13,14,16 *$ & 24 & 36 & 48 \\
\hline 1.0 & 1 & 42.92 & 42. & & 44.39 & 41.85 & 39.60 \\
\hline psi & $\underline{55.90}$ & 43.51 & 42.94 & 45 & 46.94 & 42.22 & 41.84 \\
\hline Ave. & 52.76 & 43.22 & 42.59 & $4 \overline{4} .92^{-}$ & $45.6 \overline{7}$ & $\overline{42.07}$ & 40.72 \\
\hline 2.0 & 47.54 & 40.42 & 39.59 & 37 & 42.45 & 41.80 & 39.48 \\
\hline$\underline{p s i}$ & 52.82 & 40.83 & 39.85 & 39.98 & 43.74 & 41.95 & 40.83 \\
\hline Ave. & 50.18 & 40.86 & 39.72 & 38.98 & 43.10 & 41.88 & 40.16 \\
\hline 4.0 & 36.23 & 36.30 & 32.34 & 34. & 36.12 & 31.46 & 36.10 \\
\hline$\underline{p s i}$ & 37.92 & 36.31 & 34.13 & $3 \underline{5}$. & 37.28 & 31.82 & 36.15 \\
\hline Ave. & 37.08 & 36.32 & 33.24 & 34.94 & 36.70 & 31.64 & 36.13 \\
\hline
\end{tabular}

* $14 \mathrm{hrs}$ for $1.0 \mathrm{psi}, 13 \mathrm{hrs}$ for $2.0 \mathrm{psi}$ and $16 \mathrm{hrs}$ for $4.0 \mathrm{psi}$ 
Table A-11, cont.

(c) Soil 5

\begin{tabular}{|c|c|c|c|c|c|c|c|}
\hline $\begin{array}{l}\text { Time (hr) } \\
\text { Pressure (psi) }\end{array}$ & 1 & 2 & 4 & 13,14, & 24 & 36 & 48 \\
\hline 1.0 & 27.23 & 24.96 & 27.23 & 25. & 24.73 & 24.12 & 24.07 \\
\hline psi & & 25.52 & 27.62 & 26.21 & 25.26 & 24.29 & 24.29 \\
\hline Ave. & 27.23 & 25.24 & 27.43 & 25.91 & 25.00 & 24.46 & 24.18 \\
\hline 2.0 & 28.01 & 26.19 & 25.93 & 25.07 & 26.74 & 25.90 & 26.49 \\
\hline$\underline{p s i}$ & 29.18 & 27.38 & 26.01 & 25.84 & 27.45 & 26.33 & 26.56 \\
\hline Ave. & 28.60 & 26.79 & 25.97 & 25.46 & 27.10 & 26.12 & 26.53 \\
\hline 4.0 & 24.67 & 14.34 & 15.58 & 23.85 & 16.24 & 15.96 & 23.81 \\
\hline psi & 24.55 & 15.90 & 16.04 & 24.05 & 17.38 & 16.51 & 23.85 \\
\hline Ave. & 24.61 & 15.12 & 15.81 & 23.95 & 16.81 & 16.24 & 23.83 \\
\hline
\end{tabular}

*14 hrs for 1.0 psi, $13 \mathrm{hrs}$ for $2.0 \mathrm{psi}$ and $16 \mathrm{hrs}$ for $4.0 \mathrm{psi}$

(d) Soil 6

\begin{tabular}{|c|c|c|c|c|c|c|c|}
\hline Pressure (psi) & 1 & 2 & 4 & 13,1 & 24 & 36 & 48 \\
\hline 1.0 & 33.33 & 30.53 & 32.31 & 30.25 & 30.84 & 31.28 & 31.19 \\
\hline psi & 36.26 & 32.00 & 32.88 & 32.62 & 31.56 & 21.63 & 31.32 \\
\hline Ave. & 34.80 & 31.27 & $32 . \overline{60}$ & $3 \overline{1} .4 \overline{4}$ & $3 \overline{1} .20$ & $\overline{31} . \overline{46}$ & 31.26 \\
\hline 2.0 & 32.19 & 29.30 & 28.20 & 29.10 & 29.62 & 29.38 & 30.12 \\
\hline$\underline{1}$ & 37 & 30.25 & 28.56 & 29 & 30.03 & 30.06 & 30.72 \\
\hline Ave & 34.80 & 29.78 & 28.38 & 29.20 & $29.8 \overline{3}$ & $\overline{29} . \overline{72}$ & $30 . \overline{42}$ \\
\hline 4.0 & 26.05 & 21.84 & 27.34 & 25.99 & 25.35 & 16.88 & 24.77 \\
\hline 5 & 27.11 & 22.76 & 28.20 & -26.37 & 26.60 & 17.55 & 25.39 \\
\hline Ave & 26.58 & 22.30 & 17.77 & 26.18 & 25.98 & 17.22 & 25.08 \\
\hline
\end{tabular}

* $14 \mathrm{hrs}$ for $1.0 \mathrm{psi}, 13 \mathrm{hrs}$ for $2.0 \mathrm{psi}$ and $16 \mathrm{hrs}$ for $4.0 \mathrm{psi}$ 


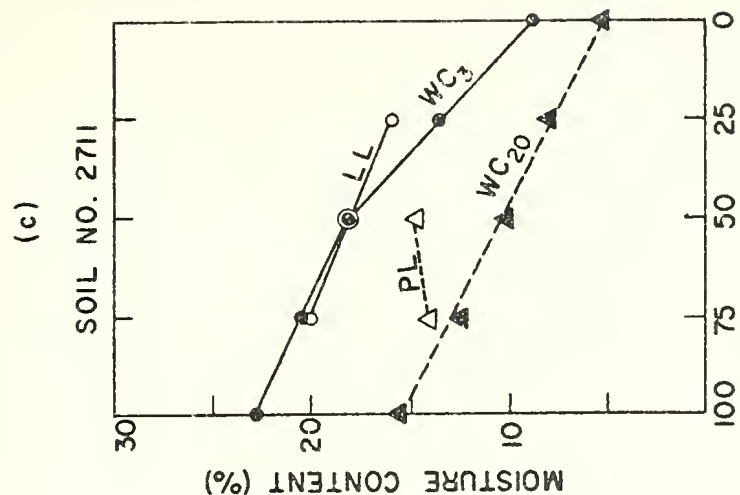

겅

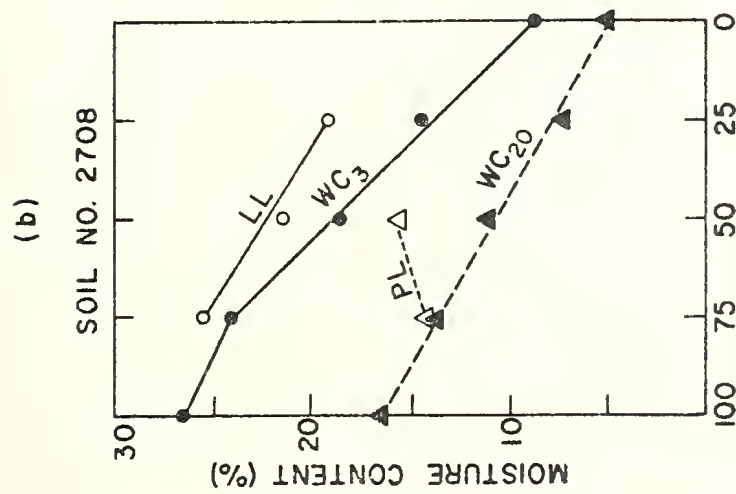

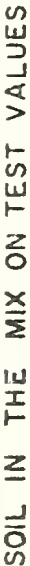

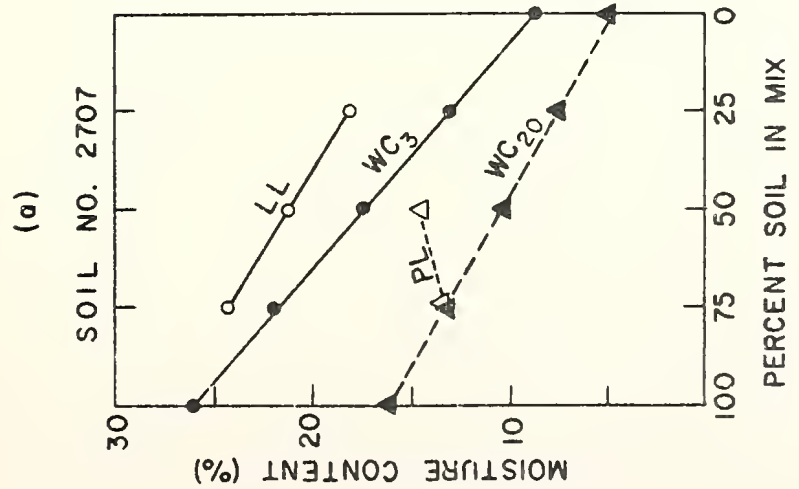

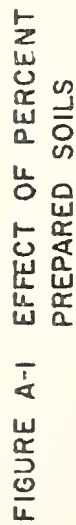




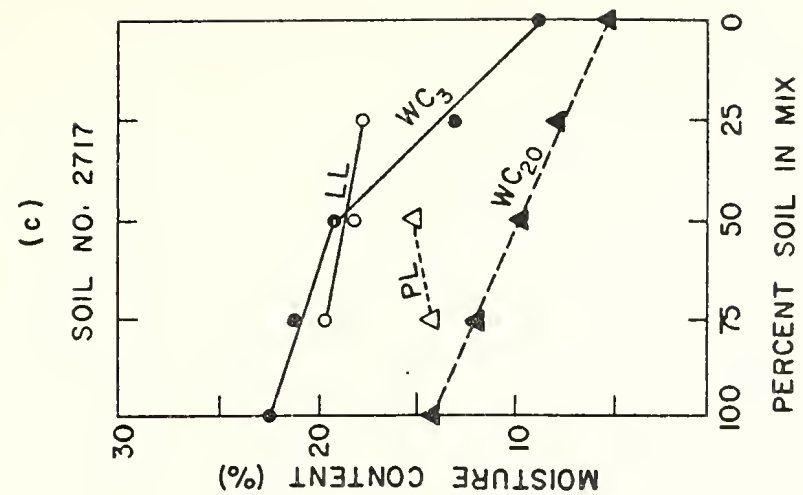

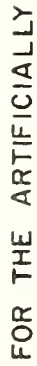

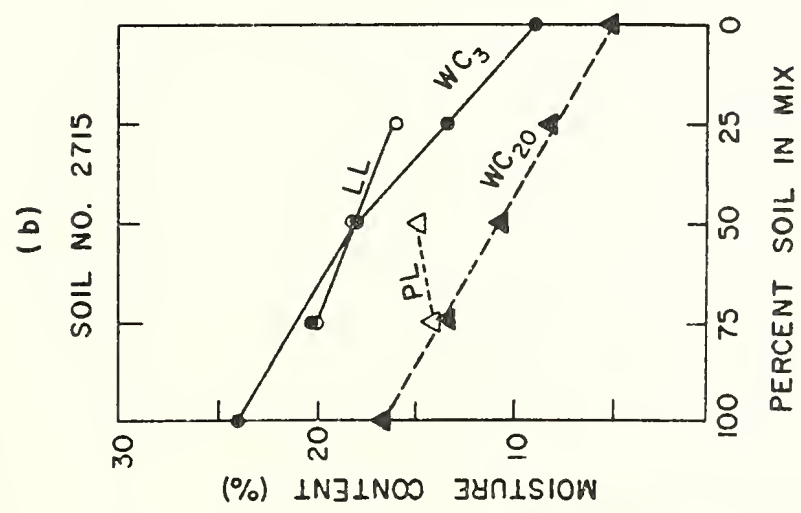

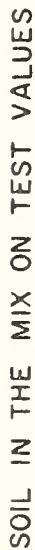

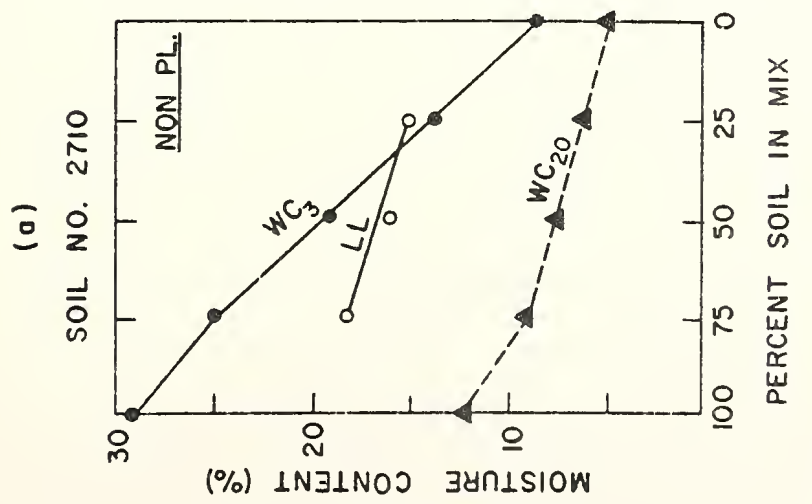

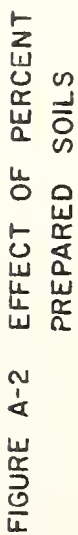



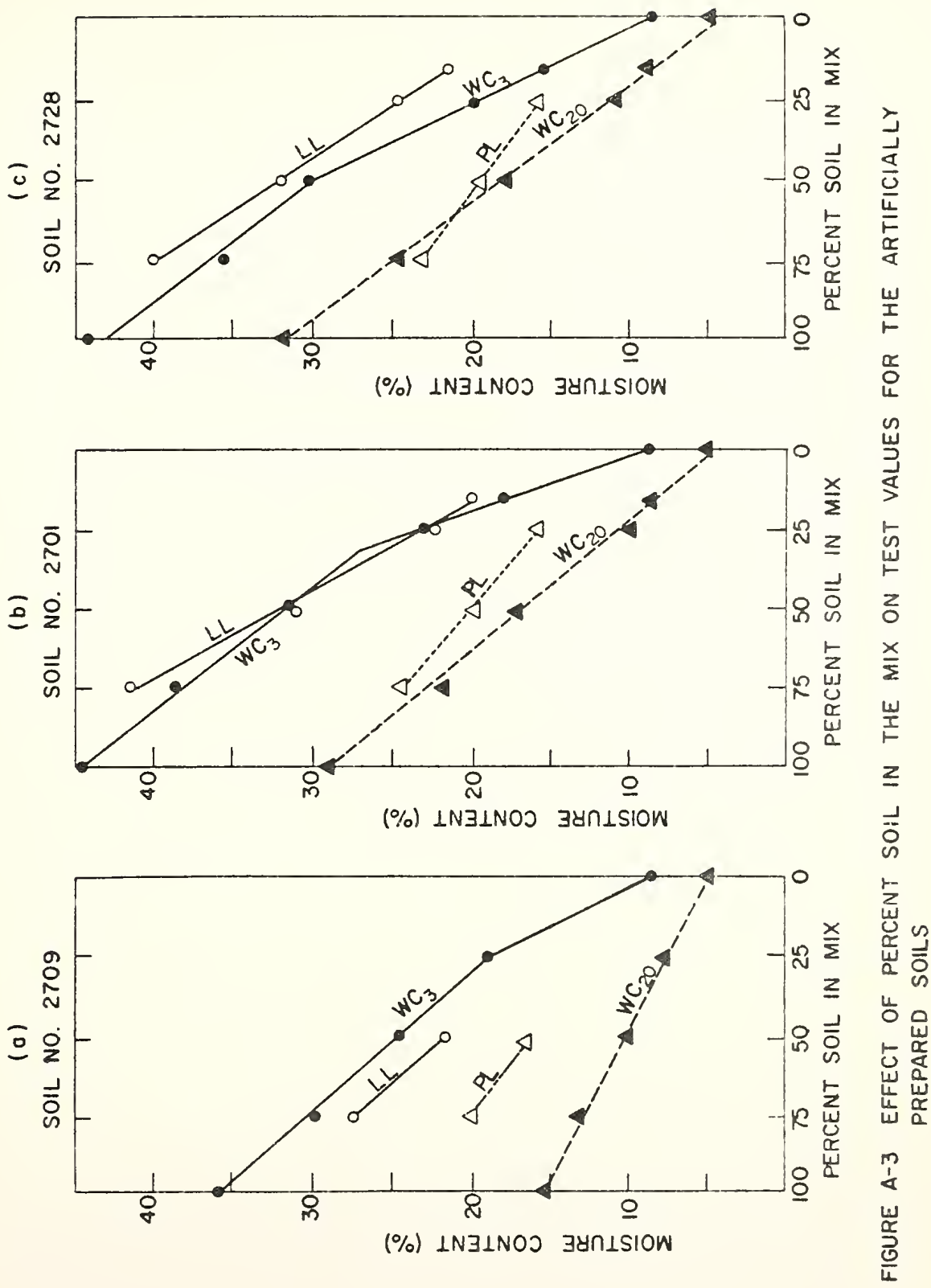
APPENDIX B

Tests for Operator Effect 


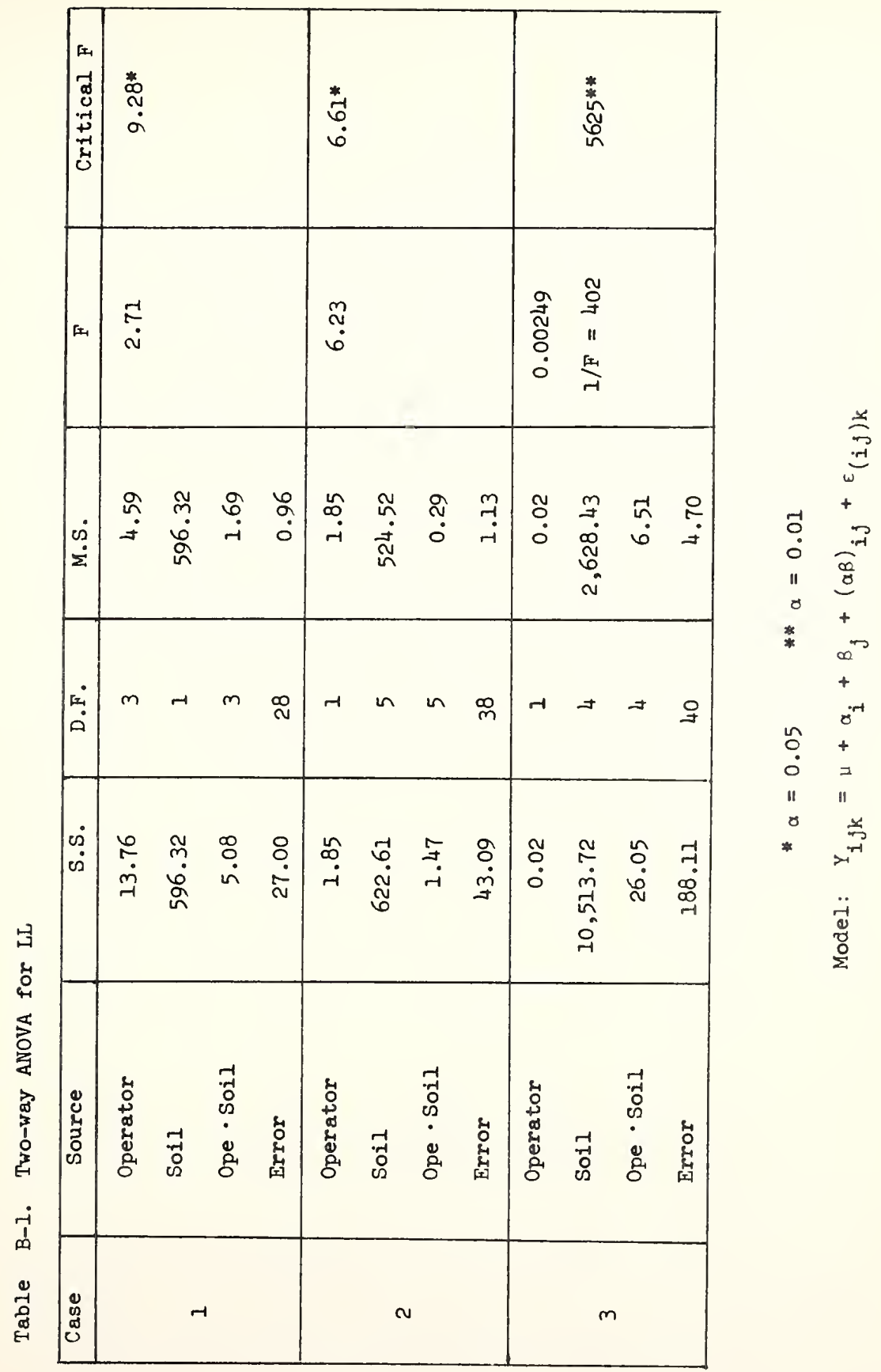




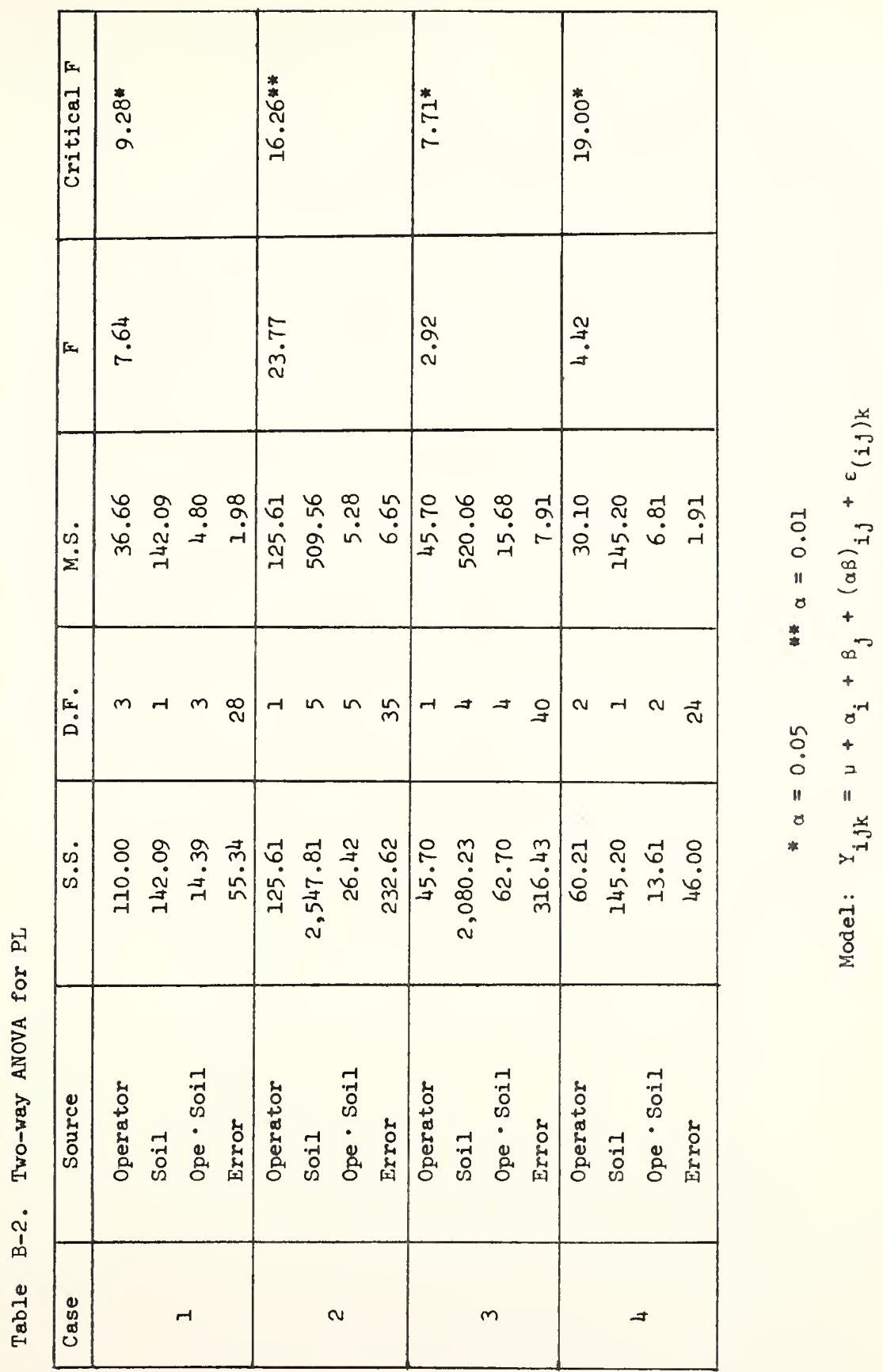


Table B-3. Tests Between Two Operators, LL

\begin{tabular}{|c|c|c|c|c|c|c|}
\hline Case & $q^{(1)}$ & Critical $q$ & $\bar{D}^{(2)}$ & $s_{\frac{2}{D}}^{(3)}$ & $t^{(4)}$ & critical $t$ \\
\hline 4 & 0.50 & $0.89^{*}$ & 3.05 & 0.82 & 3.38 & $t(3)=5.81^{* *}$ \\
\hline 5 & 0.54 & $0.72^{*}$ & 1.98 & 0.75 & 2.28 & $t(7)=2.37^{*}$ \\
\hline 6 & 0.58 & $0.72^{*}$ & -0.68 & 1.15 & -0.64 & $t(7)=2.37^{*}$ \\
\hline 7 & 0.50 & $0.72^{*}$ & 0.13 & 0.75 & 0.14 & $t(7)=2.37^{*}$ \\
\hline
\end{tabular}

Table B-4. Tests Between Two Operators, PL

\begin{tabular}{|c|c|c|c|c|c|c|}
\hline Case & $q^{(1)}$ & Critical $q$ & $\bar{D}^{(2)}$ & $s_{\frac{1}{D}}^{(3)}$ & $t^{(4)}$ & critical $t$ \\
\hline 5 & 0.57 & $0.89^{*}$ & 4.83 & 1.80 & 3.60 & $t(3)=3.18^{*}$ \\
\hline 6 & 0.51 & $0.89^{*}$ & 0.18 & 0.92 & 0.19 & $t(3)=3.18^{*}$ \\
\hline 7 & 0.65 & $0.75^{*}$ & -4.87 & 0.88 & -5.18 & $t(6)=2.45^{*}$ \\
\hline 8 & 0.54 & $0.75^{*}$ & -0.84 & 0.26 & -1.94 & $t(6)=2.45^{*}$ \\
\hline
\end{tabular}

$$
\text { * } \alpha=0.05 \quad * * \alpha=0.01
$$

(1) q: is expressed in the following equation for the Q-test for equality of variances.

$$
q=\frac{\Sigma S j^{4}}{\left(\Sigma S j^{2}\right)^{2}}
$$

Sj denotes the jth sample variance. (2) $\bar{D}=\begin{aligned} & \text { the average difference between the observations by two } \\ & \text { operators. }\end{aligned}$

(3) $S_{\bar{D}}^{2}=S_{D}^{2} / n$

$n=$ number of observations.

(4) $t=\bar{D} / S_{\bar{D}}$ 
APPENDIX C

Input Data for Regression Analysis 
Table C-1. Input Data for the all Randon Combination Analysis

\begin{tabular}{|c|c|c|c|c|c|c|}
\hline Soll No. & $\begin{array}{r}\text { L.L. } \\
(\%) \\
\end{array}$ & $\begin{array}{l}\text { P.L. } \\
(\%) \\
\end{array}$ & $\begin{array}{c}\text { Operator } \\
(\%)\end{array}$ & $\begin{array}{l}W_{3} \\
(\%)\end{array}$ & $\begin{array}{l}W_{20} \\
(\%)\end{array}$ & $\begin{array}{c}\text { Operator } \\
(\%)\end{array}$ \\
\hline \multirow{11}{*}{1} & 46.0 & 27.7 & C & 43.75 & 30.64 & $\mathrm{H}$ \\
\hline & 56.0 & 32.7 & C & 43.25 & 29.72 & $\mathrm{H}$ \\
\hline & 50.7 & 30.7 & C & 43.03 & 28.02 & I \\
\hline & 46.9 & 28.0 & C & 43.69 & 29.92 & I \\
\hline & 50.3 & 29.7 & D & 43.83 & 32.66 & H \\
\hline & 53.0 & 30.5 & D & 47.07 & 28.89 & H \\
\hline & 48.4 & 26.2 & D & 44.37 & 28.11 & $J$ \\
\hline & 49.6 & 27.8 & D & 43.94 & 26.89 & $\mathrm{~J}$ \\
\hline & 50.6 & 29.8 & D & 44.43 & 28.89 & $\mathrm{H}$ \\
\hline & 51.0 & 29.2 & $\mathbf{E}$ & 46.06 & 30.07 & I \\
\hline & 48.0 & 25.8 & $F$ & 45.39 & 26.53 & $\mathrm{~J}$ \\
\hline \multirow[b]{2}{*}{2} & & 28.8 & A & 43.64 & 27.72 & $\mathrm{H}$ \\
\hline & 47.8 & 26.3 & $F$ & 43.16 & 29.25 & $\mathrm{H}$ \\
\hline \multirow{11}{*}{4} & 27.7 & 15.9 & A & 31.64 & 16.91 & $\mathrm{~J}$ \\
\hline & 26.6 & 12.4 & A & 31.19 & 19.04 & I \\
\hline & 27.4 & 15.1 & A & 27.73 & 17.54 & $\mathrm{H}$ \\
\hline & 28.3 & 16.1 & A & 30.80 & 18.14 & I \\
\hline & $29 \cdot 3$ & 18.3 & A & 30.96 & 16.64 & H \\
\hline & 26.7 & & B & 28.78 & 17.62 & $\mathrm{H}$ \\
\hline & 28.5 & & B & 33.70 & 18.73 & I \\
\hline & 28.4 & & B & 30.12 & 16.83 & $\mathrm{~J}$ \\
\hline & 27.8 & & B & 28.59 & 18.12 & H \\
\hline & 28.5 & & B & 27.18 & 16.29 & $\mathrm{~J}$ \\
\hline & 31.1 & 14.4 & $E$ & 28.07 & 17.66 & $\mathrm{H}$ \\
\hline \multirow{5}{*}{5} & 24.5 & 16.6 & A & 27.23 & 15.38 & H \\
\hline & 24.7 & 14.9 & A & 27.81 & 14.51 & $\mathrm{H}$ \\
\hline & 24.3 & & B & 26.93 & 15.87 & $\mathrm{H}$ \\
\hline & 26.0 & & B & 25.96 & 14.74 & $\mathrm{H}$ \\
\hline & 25.5 & 16.6 & $F$ & 28.50 & 25.47 & $\mathrm{H}$ \\
\hline
\end{tabular}


Table C-I, cont.

\begin{tabular}{|c|c|c|c|c|c|c|}
\hline Soll No. & $\begin{array}{r}\text { L.L. } \\
(\%) \\
\end{array}$ & $\begin{array}{r}\text { P.L. } \\
(\%) \\
\end{array}$ & $\begin{array}{c}\text { Operator } \\
(\%)\end{array}$ & $\begin{array}{l}W_{3} \\
(\%)\end{array}$ & $\begin{array}{l}W_{20} \\
(\%)\end{array}$ & $\begin{array}{c}\text { Operator } \\
(\%)\end{array}$ \\
\hline \multirow{3}{*}{6} & 27.5 & 17.7 & A & 24.93 & 15.27 & H \\
\hline & $27 \cdot 9$ & 19.1 & D & 24.47 & 15.86 & $\mathrm{H}$ \\
\hline & 25.6 & 16.3 & $F$ & 22.05 & 14.72 & $\mathrm{H}$ \\
\hline \multirow[b]{2}{*}{7} & 26.3 & & A & 26.08 & 16.68 & $I$ \\
\hline & 27.7 & 16.4 & $F$ & 28.23 & 16.79 & $\mathrm{H}$ \\
\hline \multirow{11}{*}{8} & 28.0 & 16.9 & C & 25.21 & 15.42 & H \\
\hline & 27.4 & 16.0 & c & 26.54 & 15.51 & $J$ \\
\hline & 28.0 & 17.1 & C & 26.84 & 17.11 & $J$ \\
\hline & 28.2 & 17.4 & C & 26.30 & 17.25 & I \\
\hline & 31.7 & 16.7 & $\mathrm{D}$ & 28.16 & 15.96 & $\mathrm{H}$ \\
\hline & 29.8 & 16.1 & D & 27.15 & 16.09 & $\mathrm{H}$ \\
\hline & 29.2 & 15.7 & D & 24.54 & 15.93 & $\mathrm{H}$ \\
\hline & 30.4 & 16.3 & D & 26.57 & 16.57 & I \\
\hline & 28.9 & 14.4 & D & 25.25 & 16.03 & H \\
\hline & 27.5 & 14.0 & $\mathrm{E}$ & 26.65 & 16.24 & I \\
\hline & 26.5 & 16.4 & $F$ & 26.63 & 17.06 & $\mathrm{~J}$ \\
\hline \multirow{2}{*}{9} & 30.4 & 25.3 & A & 35.47 & 15.93 & H \\
\hline & 30.5 & 23.5 & $F$ & 35.47 & 15.36 & I \\
\hline \multirow{2}{*}{10} & 21.5 & & A & 29.49 & 14.34 & I \\
\hline & 18.7 & & $F$ & 31.11 & 12.67 & $I$ \\
\hline \multirow{11}{*}{11} & 20.5 & $13 \cdot 3$ & A & 22.88 & 15.66 & $\mathrm{~J}$ \\
\hline & 20.6 & 14.7 & A. & 22.63 & 14.48 & $J$ \\
\hline & 20.8 & 15.5 & A & 21.88 & 15.25 & I \\
\hline & 20.2 & 12.2 & A & 21.57 & 14.87 & $\mathrm{H}$ \\
\hline & 20.3 & 12.7 & A & 22.95 & 14.96 & $\mathrm{H}$ \\
\hline & 19.1 & & B & 24.32 & 16.95 & I \\
\hline & 20.3 & & B & 21.42 & 25.32 & $\mathrm{H}$ \\
\hline & 20.1 & & B & 23.62 & 15.11 & $\mathrm{H}$ \\
\hline & 20.0 & & B & 21.24 & 15.48 & H \\
\hline & 20.8 & 14.8 & $E$ & 22.81 & 15.37 & H \\
\hline & 20.8 & 15.5 & $F$ & 22.51 & 15.57 & $I$ \\
\hline
\end{tabular}


Table C-l, cont.

\begin{tabular}{|c|c|c|c|c|c|c|}
\hline Soil No. & $\begin{array}{l}\text { L.L. } \\
(\%)\end{array}$ & $\begin{array}{l}\text { P.L. } \\
(\%)\end{array}$ & $\begin{array}{r}\text { Operator } \\
(\%)\end{array}$ & $\begin{array}{l}W_{3} \\
(\%)\end{array}$ & $\begin{array}{c}W_{20} \\
(\%) \\
\end{array}$ & $\begin{array}{c}\text { Operator } \\
(\%)\end{array}$ \\
\hline \multirow{4}{*}{12} & 23.5 & 14.8 & A & 22.45 & 13.30 & H \\
\hline & 22.2 & & B & 18.68 & 11.74 & $J$ \\
\hline & 21.4 & 17.7 & $E$ & 22.95 & 13.20 & I \\
\hline & 22.6 & 20.4 & $F$ & 22.40 & 11.99 & H \\
\hline \multirow{2}{*}{14} & 18.4 & & A & 24.85 & 10.00 & H \\
\hline & 17.7 & & $F$ & 25.75 & 10.76 & I \\
\hline \multirow{3}{*}{15} & 25.8 & 16.7 & A & 24.82 & 16.49 & I \\
\hline & 20.3 & & B & 23.64 & 15.72 & $J$ \\
\hline & 19.5 & 13.9 & $F$ & 22.65 & 16.37 & $J$ \\
\hline \multirow{11}{*}{17} & 18.9 & 12.5 & A & 22.13 & 12.74 & $\mathrm{~J}$ \\
\hline & 19.3 & 13.1 & A & 22.52 & 13.90 & H \\
\hline & 19.4 & 14.6 & C & 20.95 & 14.17 & I \\
\hline & 21.0 & 15.9 & C & 22.21 & 14.56 & $\mathrm{H}$ \\
\hline & 19.3 & 14.6 & C & 21.71 & 14.38 & H \\
\hline & 19.6 & 14.0 & D & 24.10 & 14.12 & $J$ \\
\hline & 20.1 & 14.7 & D & 21.25 & 14.24 & H \\
\hline & 19.2 & 13.4 & D & 22.22 & 14.35 & H \\
\hline & 19.3 & 14.0 & D & 20.07 & 12.72 & $J$ \\
\hline & 18.4 & 13.9 & $E$ & 23.57 & 15.07 & I \\
\hline & 19.0 & 13.4 & $F$ & 23.01 & 14.29 & I \\
\hline \multirow{8}{*}{18} & 23.9 & & A & 19.32 & 11.37 & $\mathrm{~J}$ \\
\hline & 22.8 & 15.2 & A & $19 \cdot 32$ & 10.82 & $J$ \\
\hline & 25.3 & & A & 23.33 & 12.78 & $\mathrm{H}$ \\
\hline & 23.1 & 19.1 & A & 21.60 & 12.11 & $\mathrm{H}$ \\
\hline & 22.2 & 15.2 & A & 19.26 & 10.76 & I \\
\hline & 22.9 & & B & 23.38 & 12.79 & $\mathrm{H}$ \\
\hline & 20.5 & 14.7 & $E$ & 22.23 & 12.91 & I \\
\hline & 23.0 & 15.2 & $F$ & 19.15 & 11.77 & $J$ \\
\hline \multirow{4}{*}{19} & 30.8 & 21.2 & A & 16.98 & 11.51 & I \\
\hline & 27.6 & & B & 16.35 & 12.38 & H \\
\hline & 29.4 & 18.2 & E & 15.49 & 12.47 & I \\
\hline & 24.8 & & $F$ & 16.26 & 10.79 & I \\
\hline
\end{tabular}


Table C-I, cont.

\begin{tabular}{|c|c|c|c|c|c|c|}
\hline Soil No. & $\begin{array}{r}\text { L.L. } \\
(\%) \\
\end{array}$ & $\begin{array}{l}\text { P.L. } \\
(\%)\end{array}$ & $\begin{array}{c}\text { Operator } \\
(\%)\end{array}$ & $\begin{array}{l}W_{3} \\
(\%) \\
\end{array}$ & $\begin{array}{l}W_{20} \\
(\%)\end{array}$ & $\begin{array}{c}\text { Operator } \\
(\%)\end{array}$ \\
\hline 22 & $\begin{array}{l}24.9 \\
22.7 \\
20.9\end{array}$ & $\begin{array}{l}18.0 \\
17.0 \\
\end{array}$ & $\begin{array}{l}\mathrm{A} \\
\mathrm{B} \\
\mathrm{F}\end{array}$ & $\begin{array}{l}27.11 \\
27.60 \\
24.99 \\
\end{array}$ & $\begin{array}{l}15.00 \\
15.96 \\
13.18 \\
\end{array}$ & $\begin{array}{l}\mathrm{H} \\
\mathrm{H} \\
\mathrm{I}\end{array}$ \\
\hline 28 & $\begin{array}{l}56.8 \\
54.8 \\
65.7 \\
55.0 \\
61.0 \\
58.2 \\
57.4 \\
58.2 \\
57.6 \\
56.3\end{array}$ & $\begin{array}{l}29.6 \\
27.7 \\
30.4 \\
28.5 \\
30.3 \\
29.9 \\
28.7 \\
29.2 \\
29.0 \\
27.1\end{array}$ & $\begin{array}{l}\mathrm{C} \\
\mathrm{C} \\
\mathrm{C} \\
\mathrm{C} \\
\mathrm{C} \\
\mathrm{D} \\
\mathrm{D} \\
\mathrm{D} \\
\mathrm{D} \\
\mathrm{D}\end{array}$ & $\begin{array}{l}42.42 \\
43.36 \\
41.28 \\
45.74 \\
42.70 \\
45.59 \\
41.38 \\
46.95 \\
43.27 \\
42.29\end{array}$ & $\begin{array}{l}29.76 \\
30.63 \\
30.24 \\
32.66 \\
31.82 \\
33.03 \\
32.09 \\
32.43 \\
32.20 \\
30.47\end{array}$ & $\begin{array}{l}\mathrm{H} \\
\mathrm{H} \\
\mathrm{J} \\
\mathrm{I} \\
\mathrm{H} \\
\mathrm{J} \\
\mathrm{H} \\
\mathrm{J} \\
\mathrm{I} \\
\mathrm{H}\end{array}$ \\
\hline
\end{tabular}

Total number of tests for L.L. $=104$

Total number of tests for P.L. $=81$ 
Table C-2. Input Data for the Random Pull Analysis

\begin{tabular}{|c|c|c|c|c|}
\hline Dep. or Ind. Var. & \multicolumn{2}{|c|}{ Dependent Variable } & \multicolumn{2}{|c|}{ Independent Variable } \\
\hline 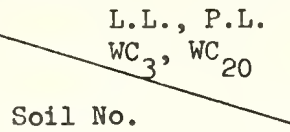 & $\begin{array}{l}\text { L.L. } \\
(\%)\end{array}$ & $\begin{array}{l}\text { P.L. } \\
(\%)\end{array}$ & $\begin{array}{l}\mathrm{WC}_{3} \\
(\%)\end{array}$ & $\begin{array}{l}{ }^{W C_{20}} \\
(\%)\end{array}$ \\
\hline 1 & 50.0 & 28.9 & 44.37 & 28.11 \\
\hline 2 & 43.2 & 27.6 & 43.16 & 29.25 \\
\hline 4 & 28.8 & 15.7 & 30.80 & 18.14 \\
\hline 5 & 25.0 & 16.0 & 27.23 & 15.38 \\
\hline 6 & 28.1 & 18.3 & 24.93 & 15.27 \\
\hline 7 & 27.0 & 16.4 & 27.17 & 16.67 \\
\hline 8 & 28.6 & 15.9 & 26.65 & 16.24 \\
\hline 9 & 30.5 & 24.4 & 35.80 & 15.71 \\
\hline 10 & 20.1 & - & 30.06 & 12.85 \\
\hline 11 & 20.2 & 14.1 & 22.88 & 15.66 \\
\hline 12 & 22.4 & 17.6 & 20.90 & 12.28 \\
\hline 14 & 18.1 & - & 23.96 & 9.56 \\
\hline 15 & 21.9 & 15.3 & 24.82 & 16.83 \\
\hline 17 & 19.3 & 14.0 & 22.22 & 14.35 \\
\hline 18 & 23.0 & 15.9 & 21.11 & 11.71 \\
\hline 19 & 28.2 & 19.7 & 17.54 & 11.39 \\
\hline 22 & 22.8 & 17.5 & 24.15 & 13.79 \\
\hline 28 & 58.1 & 29.0 & 43.36 & 30.63 \\
\hline
\end{tabular}

Number of Semples for L.L. $=18$

Number of Samples for P.L. $=16$ 
APPENDIX D

Coefficients of Variation 
Table D-1. Coefficient of Variation, $\frac{\mathrm{S}}{\overline{\mathrm{X}}} \times 100(\%)$

$$
\text { (L.L., P.L., } \mathrm{WC}_{3}, \mathrm{WC}_{20} \text { ) }
$$

\begin{tabular}{|c|c|c|c|c|}
\hline \multirow{2}{*}{\begin{tabular}{|c} 
ebserved Value \\
Soil No.
\end{tabular}} & \multicolumn{2}{|c|}{ Standard Test } & \multicolumn{2}{|c|}{ Moisture Tension } \\
\hline & L.L. & P.L. & $\mathrm{WC}_{3}$ & $\mathrm{wC}_{20}$ \\
\hline 1 & 5.6 & 7.1 & 2.8 & 6.0 \\
\hline 2 & 25.2 & 6.4 & 1.0 & 4.0 \\
\hline 4 & 7.8 & 12.9 & 6.7 & 5.0 \\
\hline 5 & 2.9 & 6.1 & 3.5 & 3.7 \\
\hline 6 & 6.2 & 14.8 & 6.6 & 3.7 \\
\hline 7 & 3.7 & - & 6.5 & 6.7 \\
\hline 8 & 5.1 & 8.0 & 3.8 & 3.9 \\
\hline 9 & 0.2 & 5.2 & $4 \cdot 3$ & 3.4 \\
\hline 10 & $9 \cdot 9$ & - & 3.6 & 8.4 \\
\hline 11 & 2.8 & 9.6 & 1.7 & 4.1 \\
\hline 12 & 3.9 & 15.9 & 9.7 & 5.9 \\
\hline 14 & 2.7 & - & 5.4 & 6.0 \\
\hline 15 & 15.7 & 12.9 & 6.6 & 3.9 \\
\hline 17 & 3.1 & 2.6 & 5.2 & 5.1 \\
\hline 18 & 5.9 & 11.4 & 5.2 & 6.9 \\
\hline 19 & 9.2 & 10.8 & 7.5 & 6.8 \\
\hline 22 & 8.8 & 4.0 & 5.2 & 8.0 \\
\hline 28 & 5.5 & 3.7 & 4.5 & 3.5 \\
\hline Average & 6.3 & 8.8 & 5.0 & 5.3 \\
\hline Std. Dev. & 4.2 & 4.2 & 2.1 & 1.6 \\
\hline
\end{tabular}


Table D-2. Coefficient of Variation, $\frac{\mathrm{S}}{\overline{\mathrm{X}}} \times 100(\%)$

(Predicted L.L. Values)

\begin{tabular}{|c|c|c|c|c|c|c|}
\hline \multirow{2}{*}{ Soil No. } & \multicolumn{3}{|c|}{ All Combination } & \multicolumn{3}{|c|}{ Random Pull } \\
\hline & 1 & 2 & 3 & 4 & 5 & 6 \\
\hline 1 & 8.5 & 4.4 & 4.7 & 8.3 & 4.2 & 4.3 \\
\hline 2 & 5.6 & 1.6 & 2.8 & 5.4 & 1.5 & 2.6 \\
\hline 4 & 4.6 & 8.2 & 5.4 & 4.3 & 7.7 & 4.8 \\
\hline 5 & 2.9 & 4.0 & 2.6 & 2.7 & 3.7 & 2.3 \\
\hline 6 & 2.9 & 6.4 & 4.3 & 2.8 & 5.8 & 3.7 \\
\hline 7 & 5.9 & $7 \cdot 3$ & 6.3 & 5.6 & 6.8 & 5.5 \\
\hline 8 & 3.3 & 4.2 & 3.0 & 3.1 & 3.9 & 2.6 \\
\hline 9 & 2.6 & 6.1 & 3.0 & 2.5 & 5.8 & 2.7 \\
\hline 10 & 5.0 & 4.4 & 4.6 & 4.6 & 4.1 & 4.0 \\
\hline$I 1$ & 3.3 & 4.0 & 3.2 & 3.1 & 3.7 & 2.8 \\
\hline 12 & 3.5 & 8.2 & 4.8 & 3.2 & 7.5 & 4.6 \\
\hline 14 & 2.6 & 5.4 & 3.5 & 2.4 & 5.0 & 2.9 \\
\hline 15 & 3.3 & 6.5 & 4.1 & 3.1 & 6.0 & 3.5 \\
\hline 17 & 3.5 & 4.9 & 3.7 & 3.3 & 4.4 & 3.1 \\
\hline 18 & 3.8 & 7.9 & 5.6 & 3.5 & 7.2 & 4.7 \\
\hline 19 & 3.6 & 4.7 & 3.6 & 3.3 & 4.2 & 3.0 \\
\hline 22 & 5.3 & 5.6 & 5.4 & 4.9 & 5.2 & 4.6 \\
\hline 28 & 5.1 & 6.9 & 5.5 & 4.9 & 6.7 & 5.1 \\
\hline Average & 4.2 & 5.6 & 4.2 & 3.8 & 5.2 & 3.7 \\
\hline Std. Dev. & 1.5 & 1.8 & 1.1 & 1.8 & 1.6 & 1.0 \\
\hline
\end{tabular}

Case The model used for calculation

$$
\begin{array}{ll}
1 & \widehat{L L}=14.97+0.0416\left(W_{20}\right)^{2} \\
2 & \widehat{L L}=11.72+0.0207\left(W_{3}\right)^{2} \\
3 & \widehat{L L}=13.10+0.0301\left(W_{3}\right)\left(W_{20}\right) \\
4 & \widehat{L L}=15.95+0.0399\left(W_{20}\right)^{2} \\
5 & \widehat{L L}=12.46+0.0186\left(W_{3}\right)^{2} \\
6 & \widehat{L L}=16.03+0.0283\left(W_{3}\right)\left(W_{20}\right)
\end{array}
$$


Table D-3. Coefficient of Variation, $\frac{\mathrm{S}}{\overline{\mathrm{X}}} \times 100(\%)$

(Predicted P.L. Values)

\begin{tabular}{|c|c|c|c|c|c|c|}
\hline \multirow{2}{*}{ Soil No. } & \multicolumn{3}{|c|}{ All Combination } & \multicolumn{3}{|c|}{ Random Pull } \\
\hline & 1 & 2 & 3 & 4 & 5 & 6 \\
\hline 1 & 6.8 & 3.6 & 3.8 & 6.3 & 3.4 & 3.5 \\
\hline 2 & 4.4 & 1.3 & 2.2 & 4.1 & 1.2 & 2.1 \\
\hline 4 & 3.1 & 6.0 & 3.8 & 2.8 & 5.4 & 3.4 \\
\hline 5 & 1.9 & 2.8 & 1.8 & 1.6 & 2.5 & 1.6 \\
\hline 6 & 1.9 & $4 \cdot 3$ & 2.9 & 1.7 & 3.8 & 2.5 \\
\hline 7 & 4.0 & 5.1 & $4 \cdot 3$ & $3 \cdot 5$ & 4.6 & 3.8 \\
\hline 8 & 2.2 & 2.9 & 2.0 & 1.9 & 2.6 & 1.8 \\
\hline 9 & 1.7 & 4.7 & 2.1 & 1.5 & 4.3 & 1.9 \\
\hline 11 & 2.2 & 2.7 & 2.1 & 1.9 & 2.3 & 1.9 \\
\hline 12 & 2.1 & 5.3 & 3.5 & 1.9 & 4.6 & 3.0 \\
\hline 15 & 2.2 & 4.4 & 2.7 & 2.0 & 3.9 & 2.4 \\
\hline 17 & 2.2 & 3.2 & 2.4 & 2.0 & 2.8 & 2.1 \\
\hline 18 & 2.3 & 5.1 & 3.5 & 2.0 & 4.5 & 3.0 \\
\hline 19 & 2.2 & 2.9 & 2.2 & 1.9 & 2.4 & 1.8 \\
\hline 22 & 3.4 & 3.9 & 3.6 & 3.0 & 3.5 & 3.1 \\
\hline 28 & 4.1 & 5.7 & 4.5 & 3.8 & 5.3 & 4.2 \\
\hline Average & 2.7 & 4.0 & 1.8 & 2.6 & 3.6 & 2.6 \\
\hline Std. Dev. & 1.7 & 1.3 & 0.9 & 1.3 & 1.2 & 0.8 \\
\hline
\end{tabular}

Case The model used for calculation

$$
\begin{aligned}
& 1 \widehat{\mathrm{PL}}=12.09+0.0179\left(\mathrm{WC}_{20}\right)^{2} \\
& 2 \widehat{\mathrm{PL}}=10.38+0.0093\left(\mathrm{WC}_{3}\right)^{2} \\
& 3 \hat{\mathrm{PL}}=11.17+0.0132\left(\mathrm{WC}_{3}\right)\left(\mathrm{WC}_{20}\right) \\
& 4 \widehat{\mathrm{PI}}=13.35+0.0168\left(\mathrm{WC}_{20}\right)^{2} \\
& 5 \widehat{\mathrm{PL}}=11.58+0.0086\left(\mathrm{WC}_{3}\right)^{2} \\
& 6 \widehat{\mathrm{PL}}=12.43+0.0122\left(\mathrm{WC}_{3}\right)\left(\mathrm{WC}_{20}\right)
\end{aligned}
$$


APPENDIX E

Moisture Tension Curves 


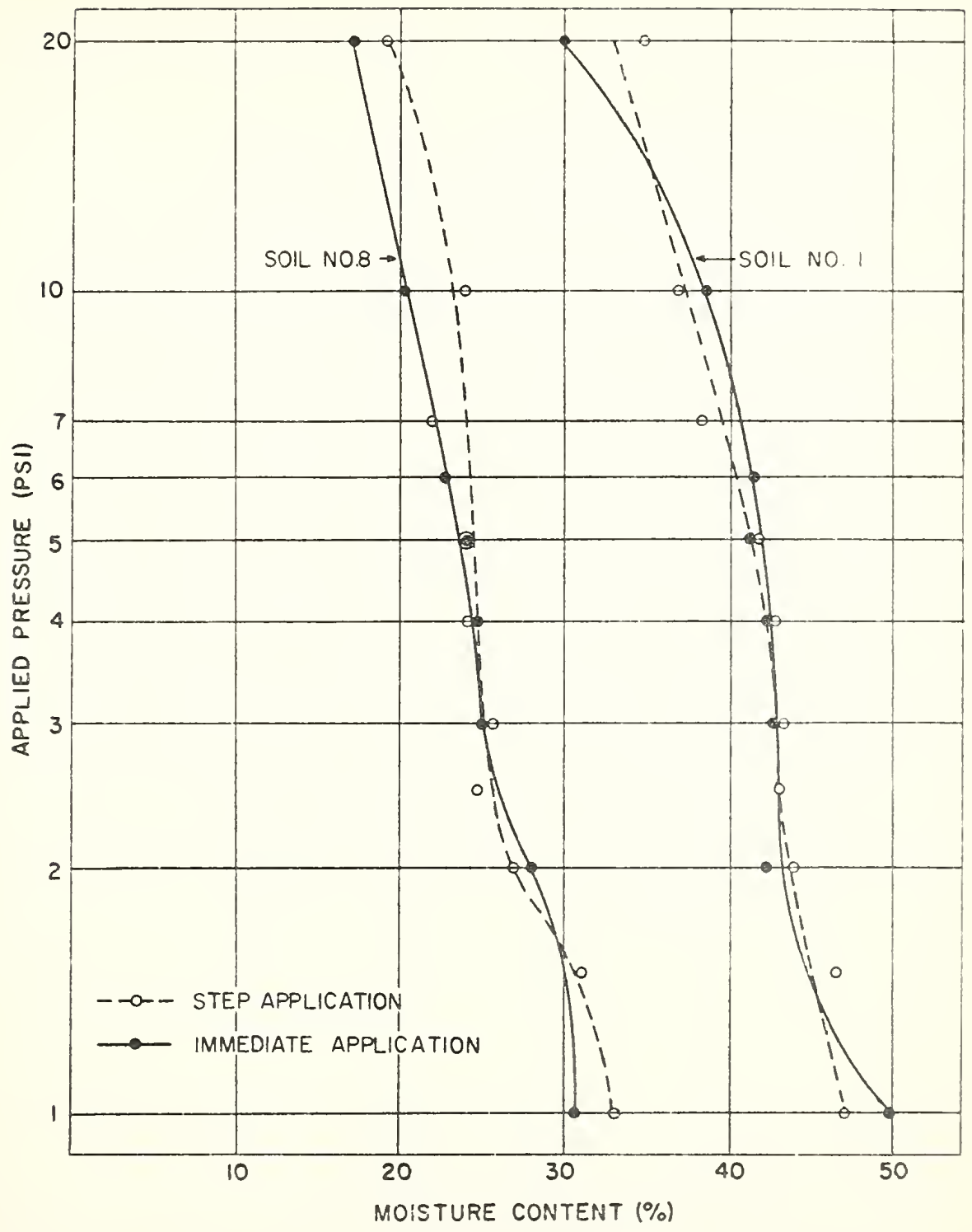

FIGURE E-I MOISTURE TENSION CURVES DEVELOPED USING TWO PROCEDURES FOR APPLYING PRESSURE 


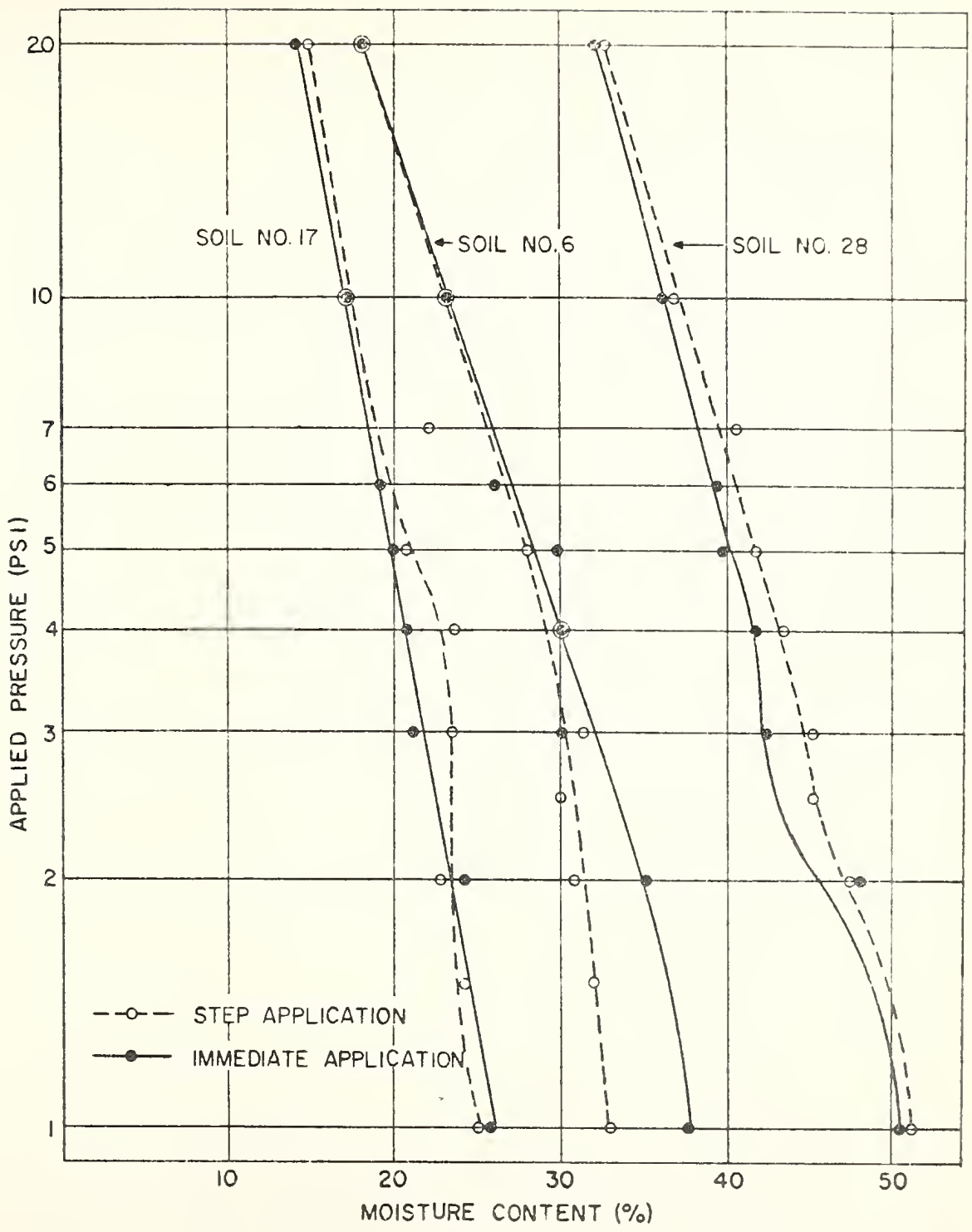

FIGURE E-2 MOISTURE TENSION CURVES DEVELOPED USING TWO PROCEDURES FOR APPLYING PRESSURE 

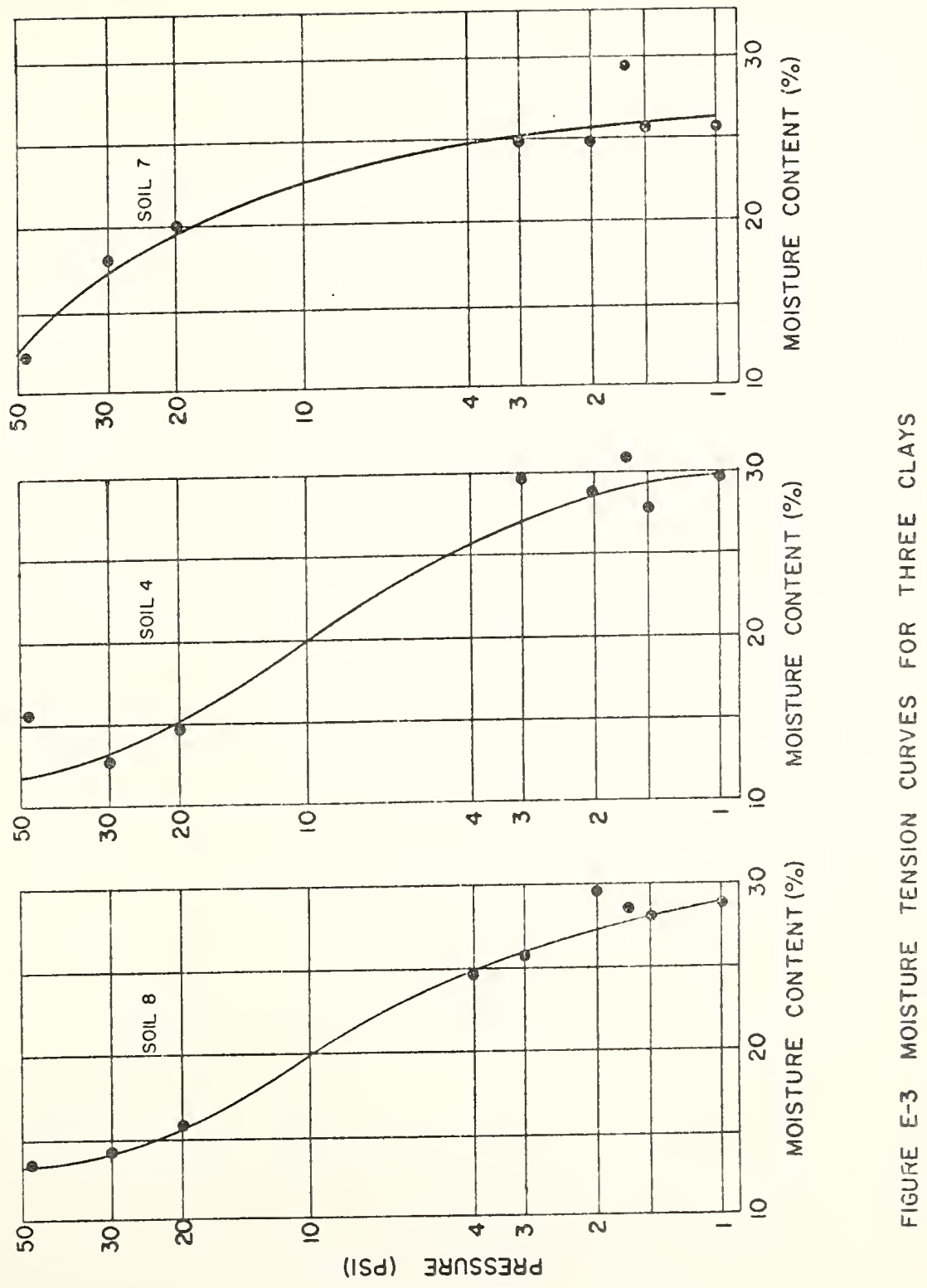


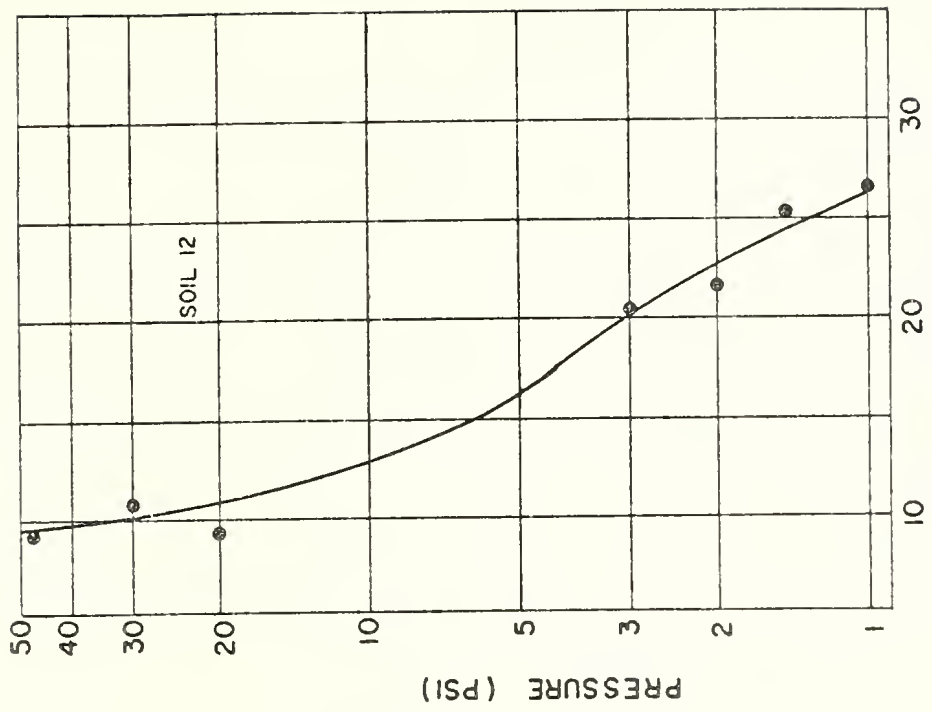

을

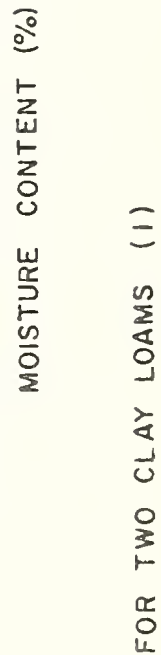

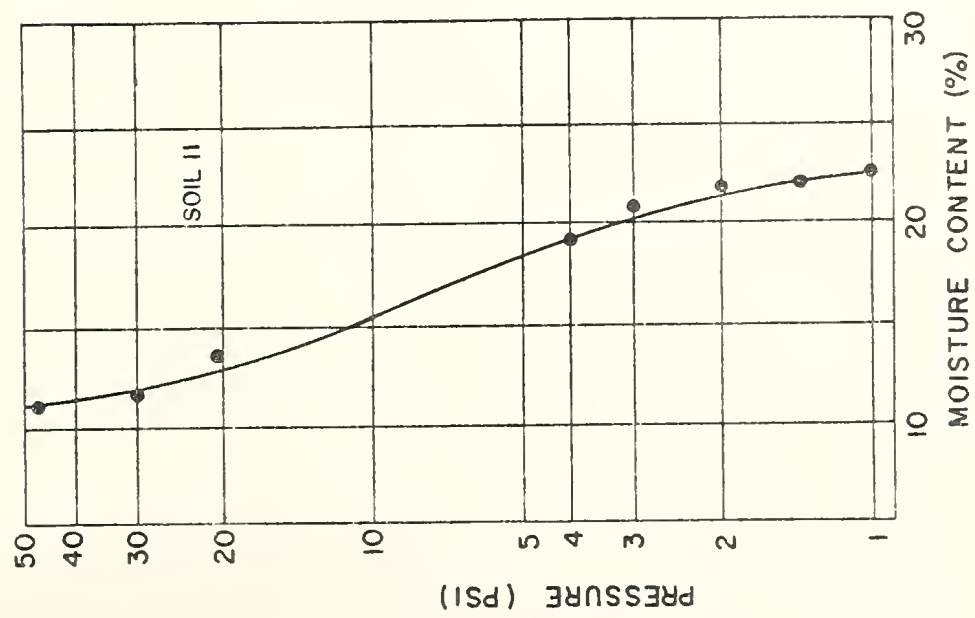

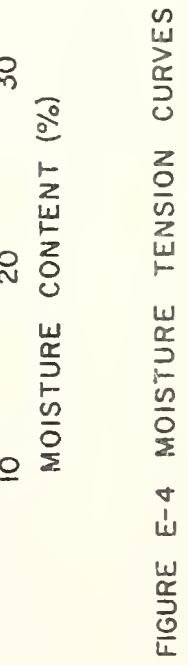




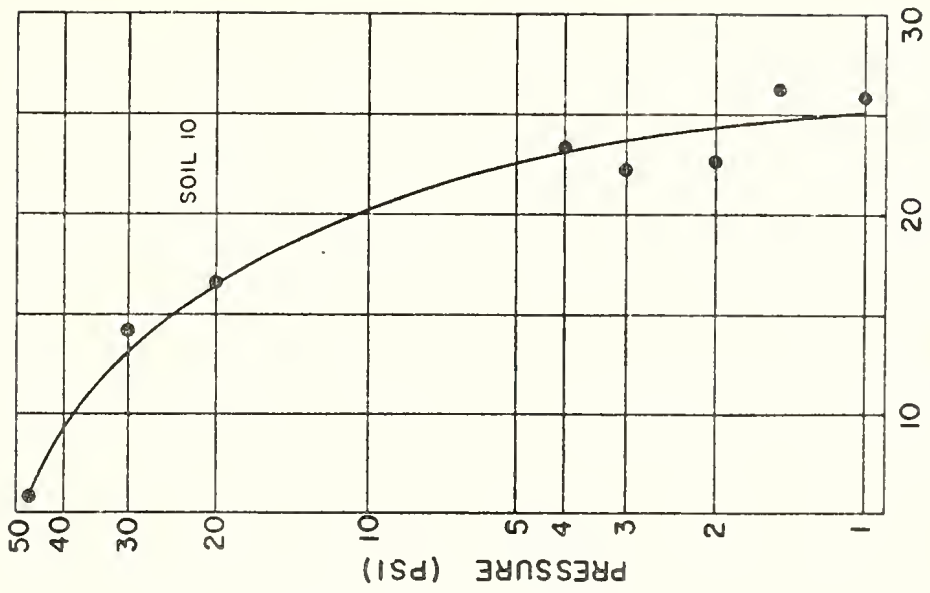

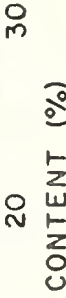

0 을

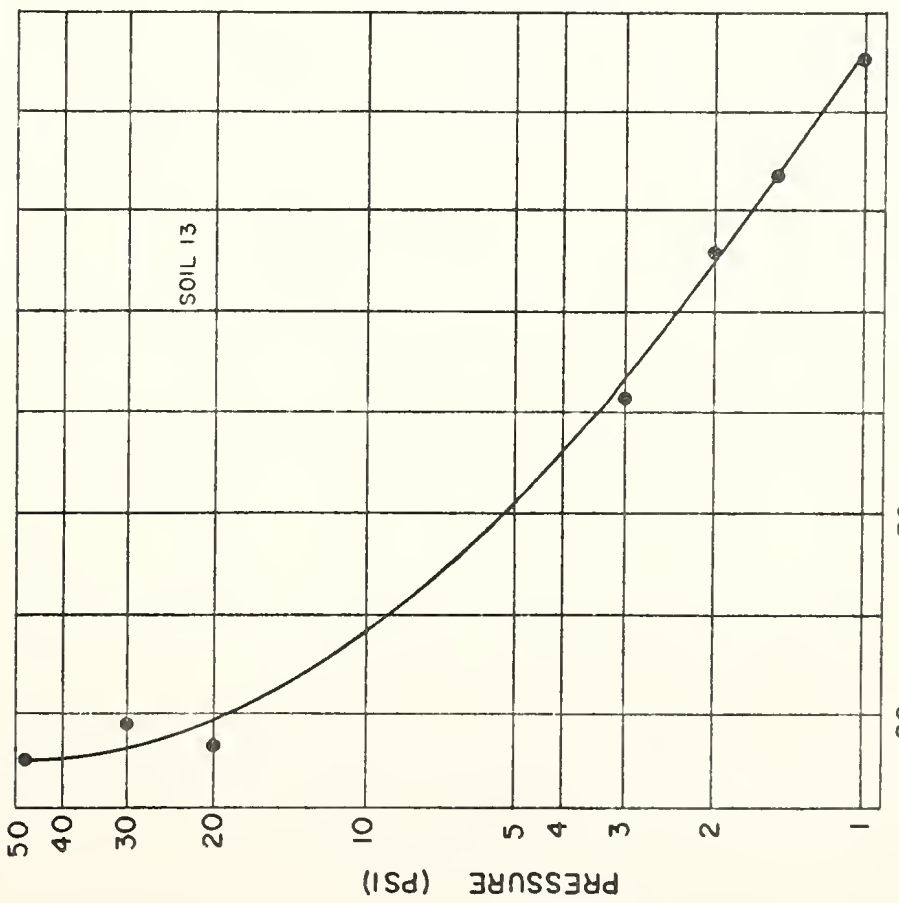

$\frac{2}{0}$

n

온

뚱

2

o $\frac{1}{z}$

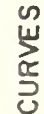

盛岕

m

$\frac{n}{2}$

$\frac{w}{\frac{w}{5}}$

ำ

w 


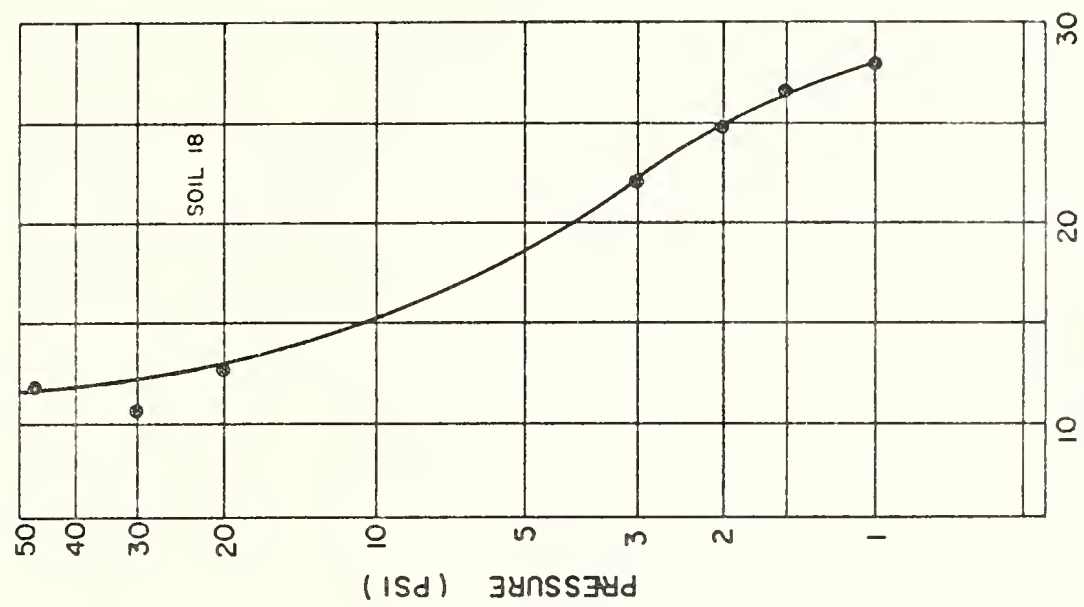

음

¿

$\sum_{w}^{\llcorner}=$

N

$\begin{array}{ll}z & = \\ 0 & 0 \\ \text { u } & \sum_{0}^{2}\end{array}$

攺

n)

- $\frac{0}{2} \frac{j}{0}$

交

3

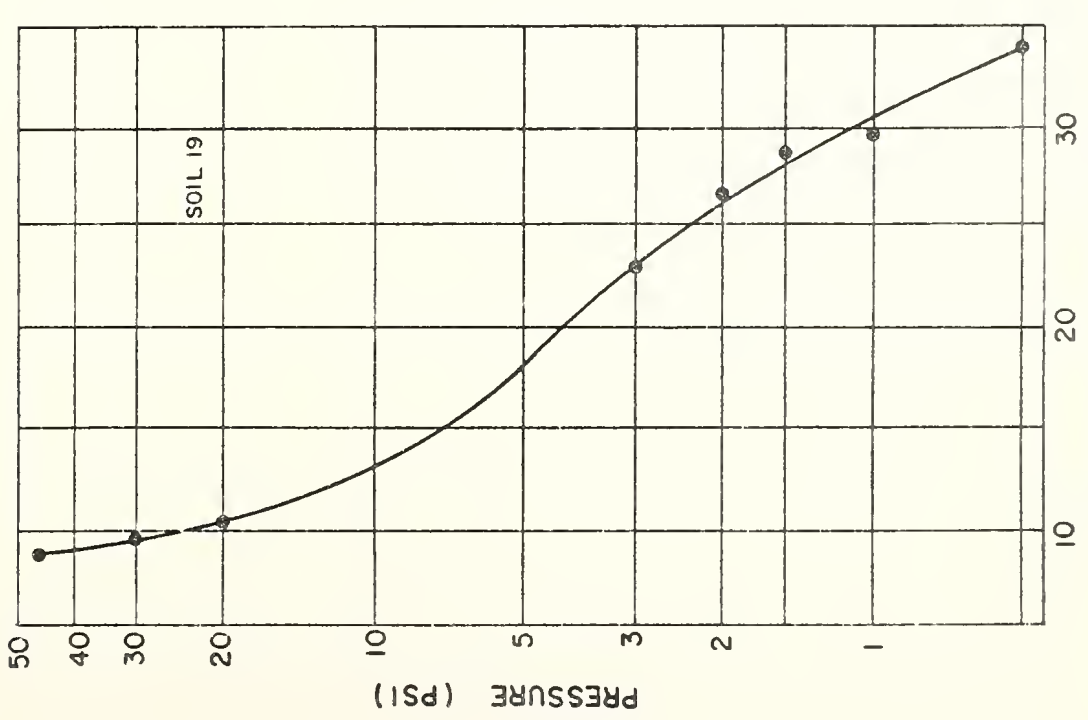

중

을

$\begin{array}{ll}\frac{2}{2} & z \\ w & \frac{0}{n} \\ z & z \\ 0 & w\end{array}$

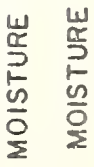

ம

w

$\frac{4}{2}$

$\frac{0}{u}$ 


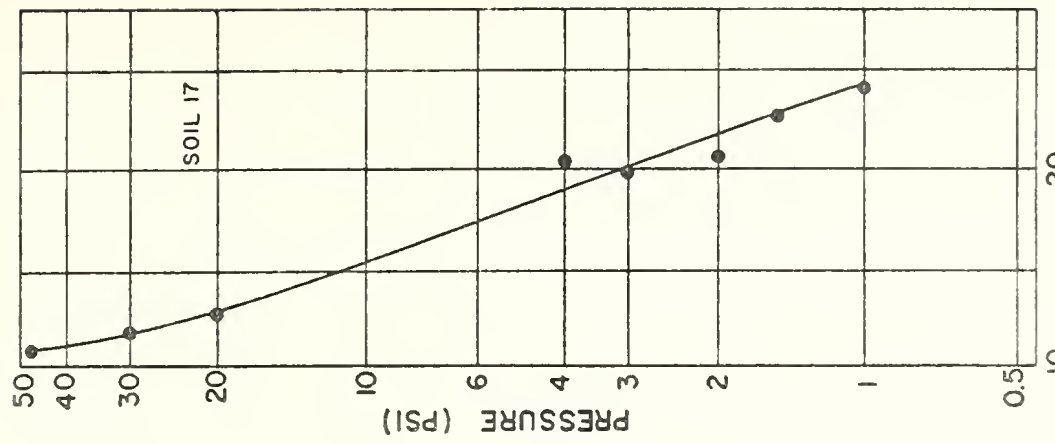

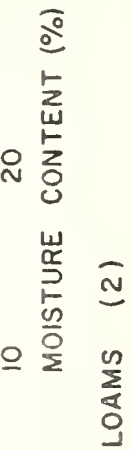

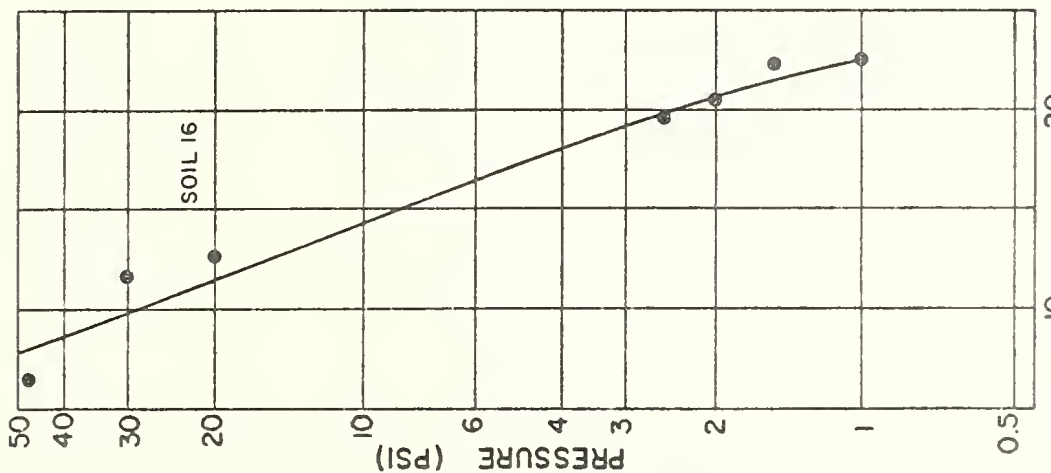

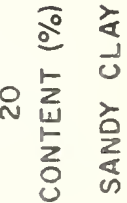

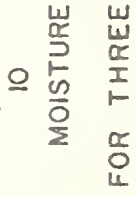

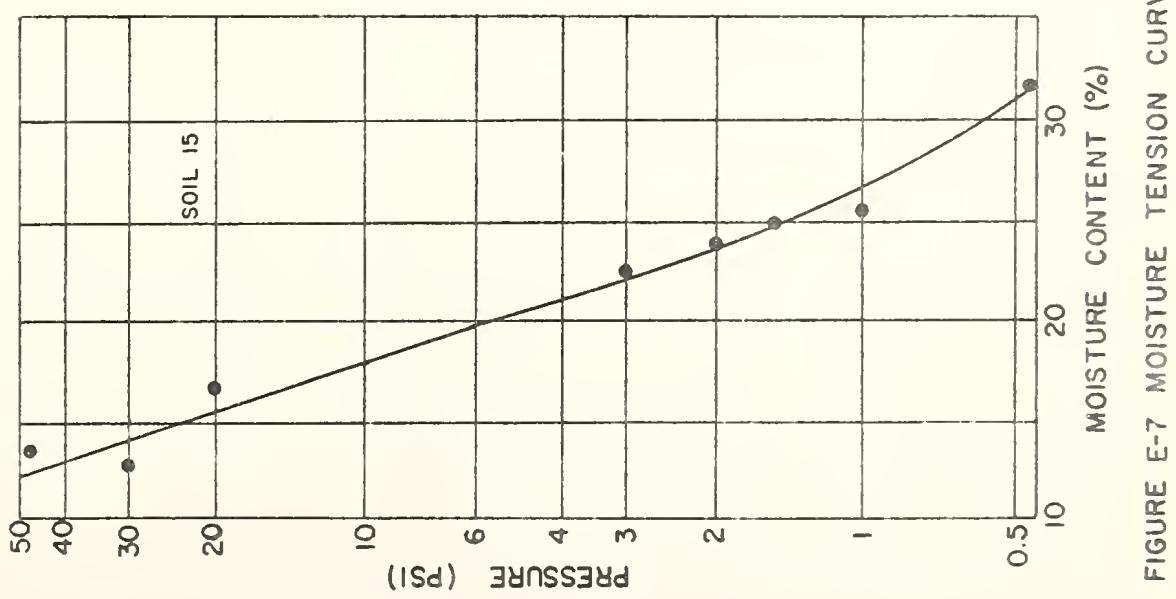



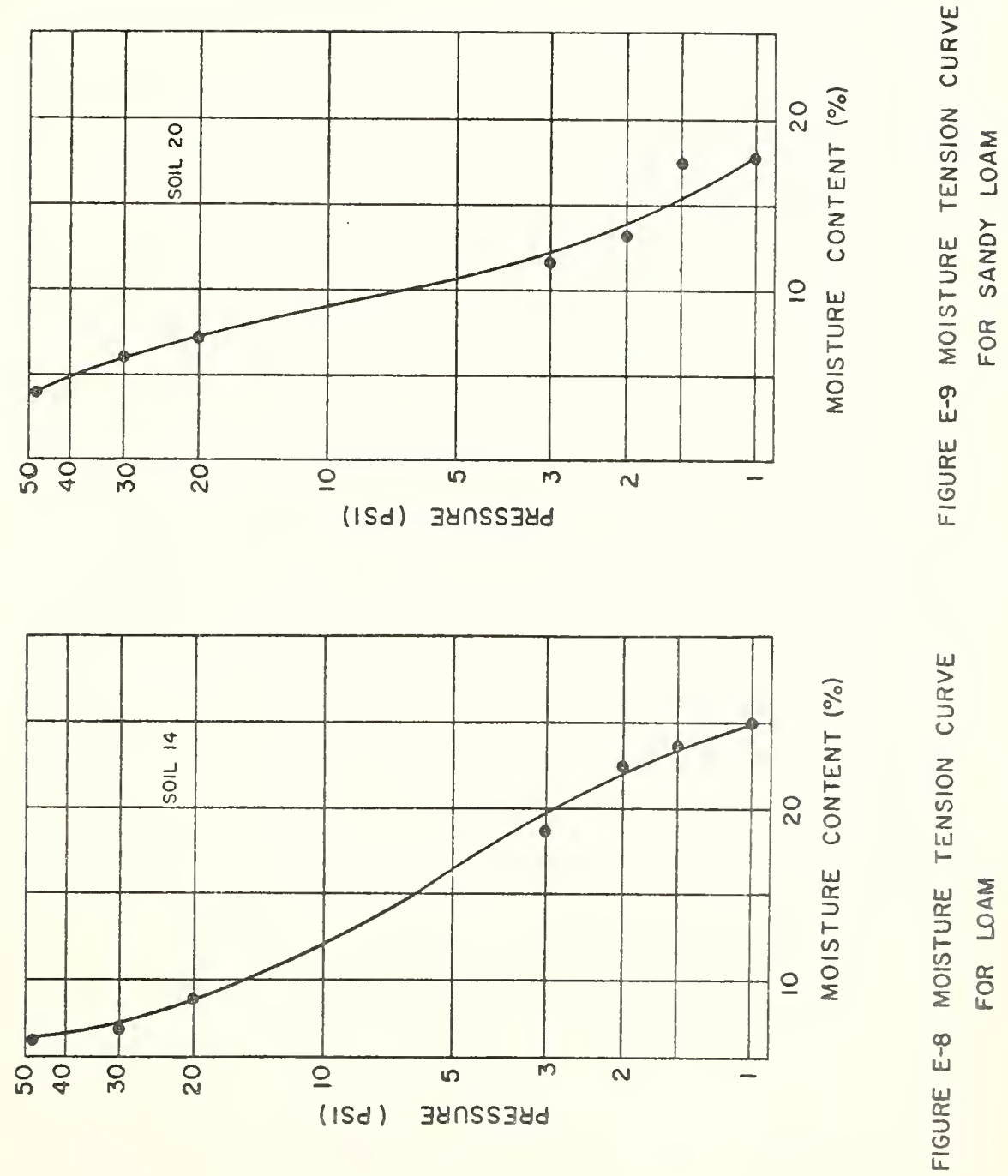


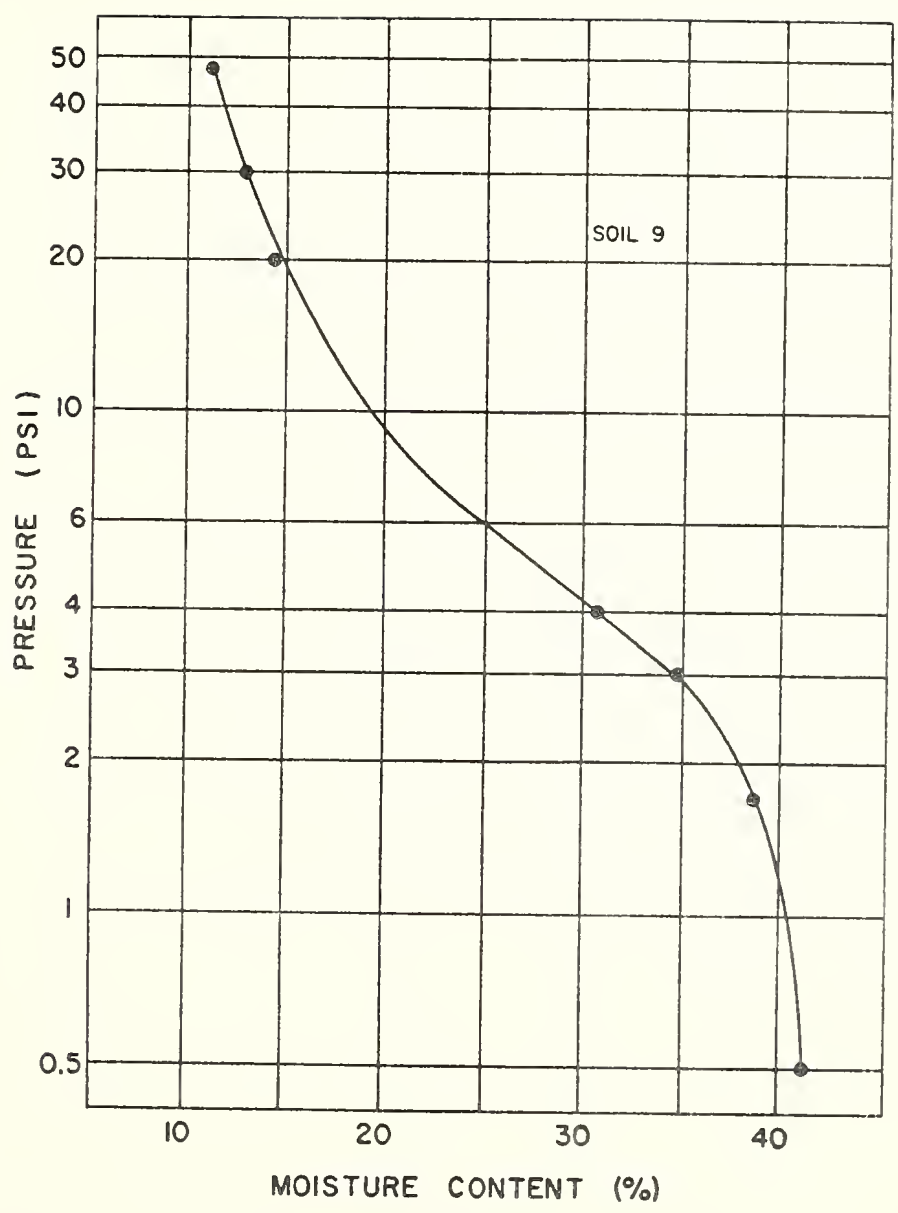

FIGURE E-IO MOISTURE TENSION CURVE FOR SILTY CLAY LOAM 
APPENDIX F

Relationships Between Molsture Tension and Soil Composition 


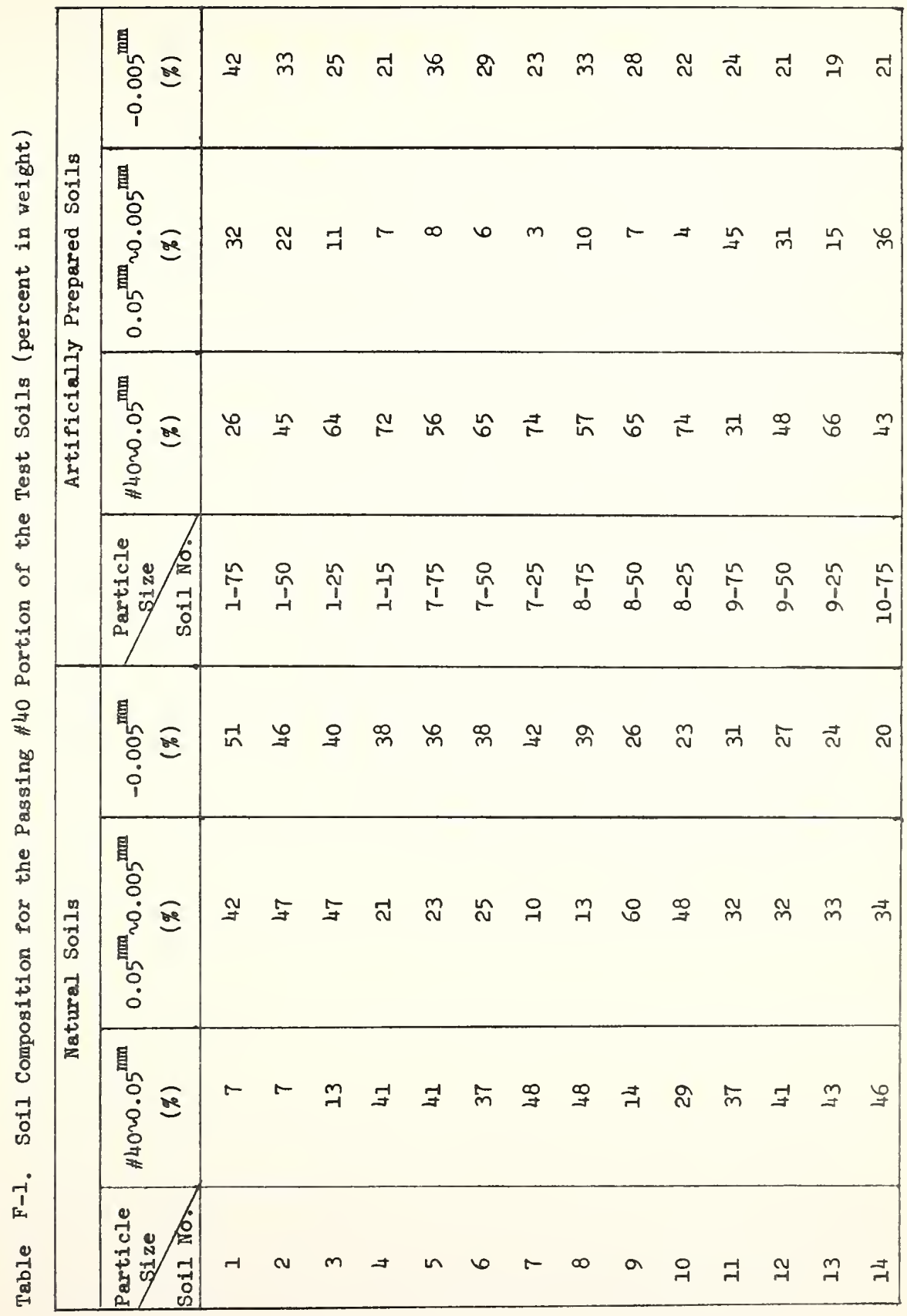




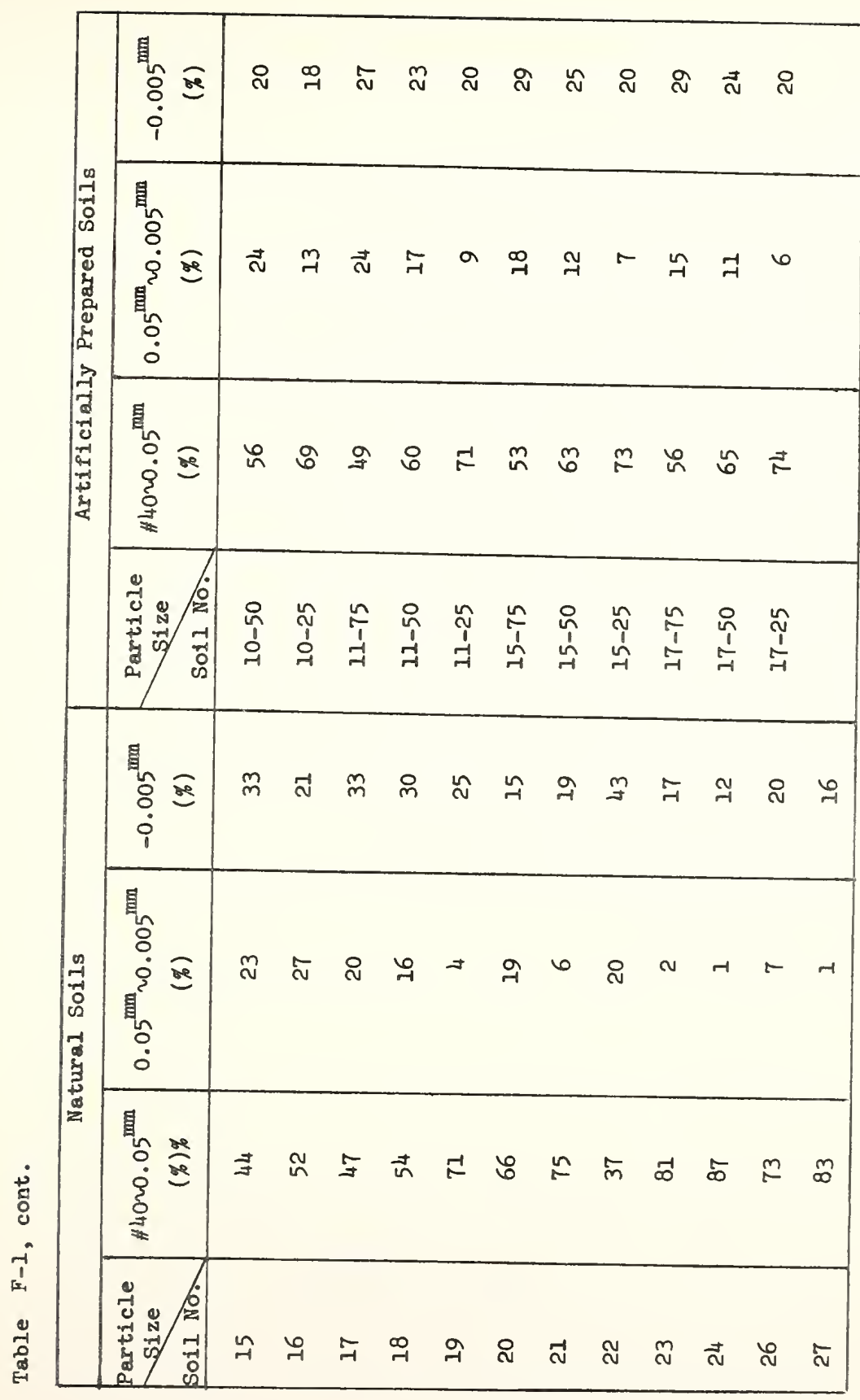




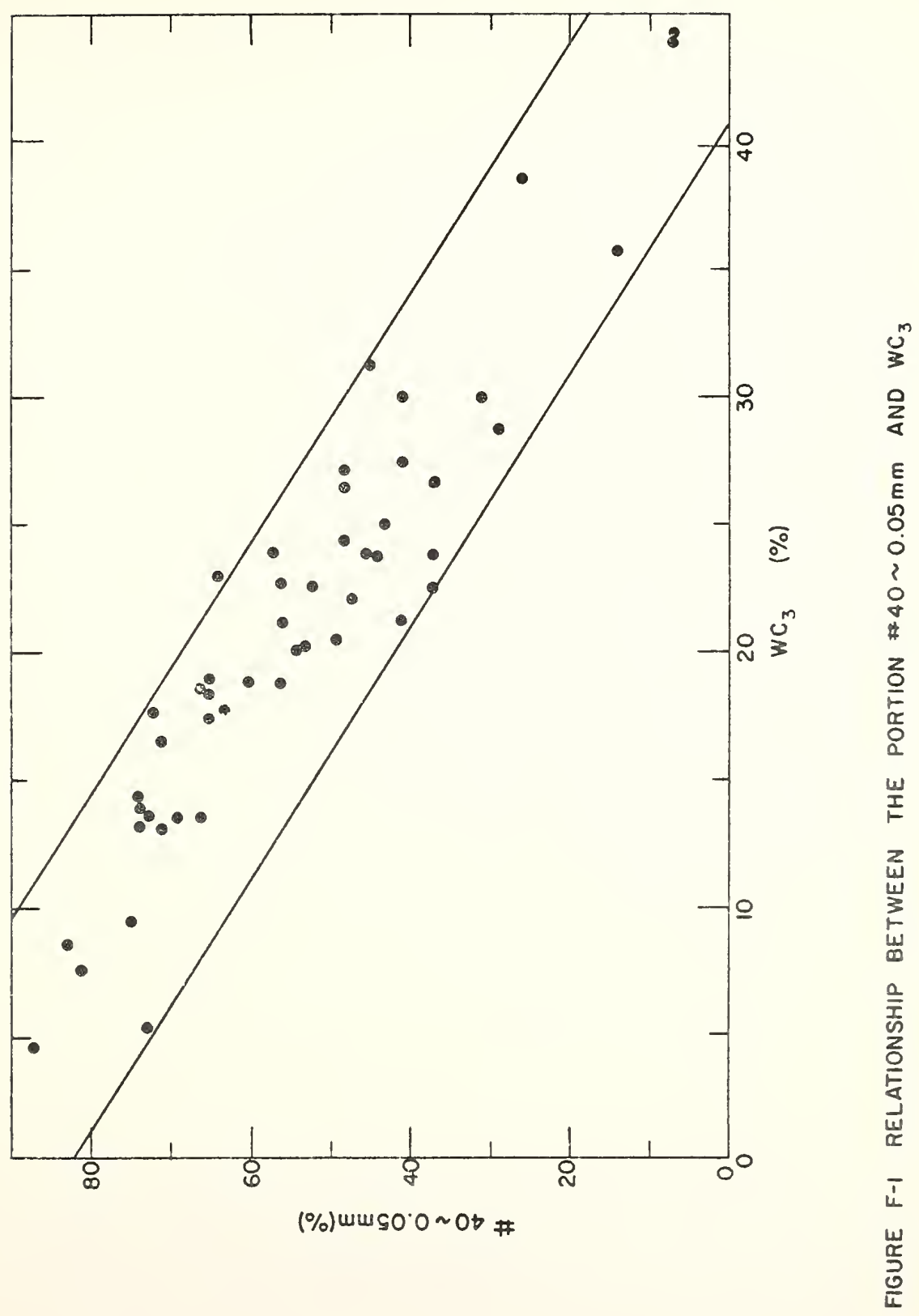


(\%) wWSOO० -

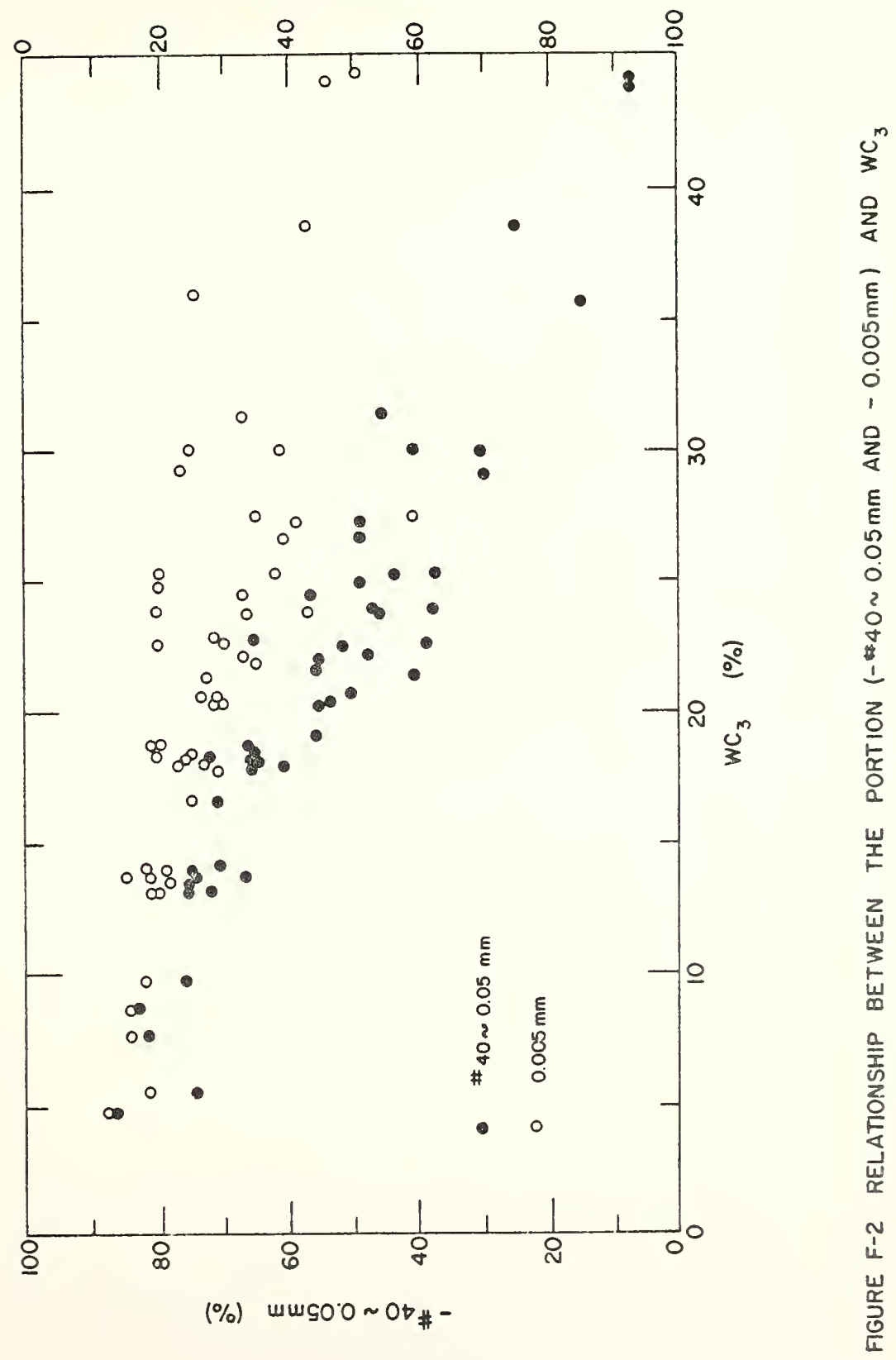




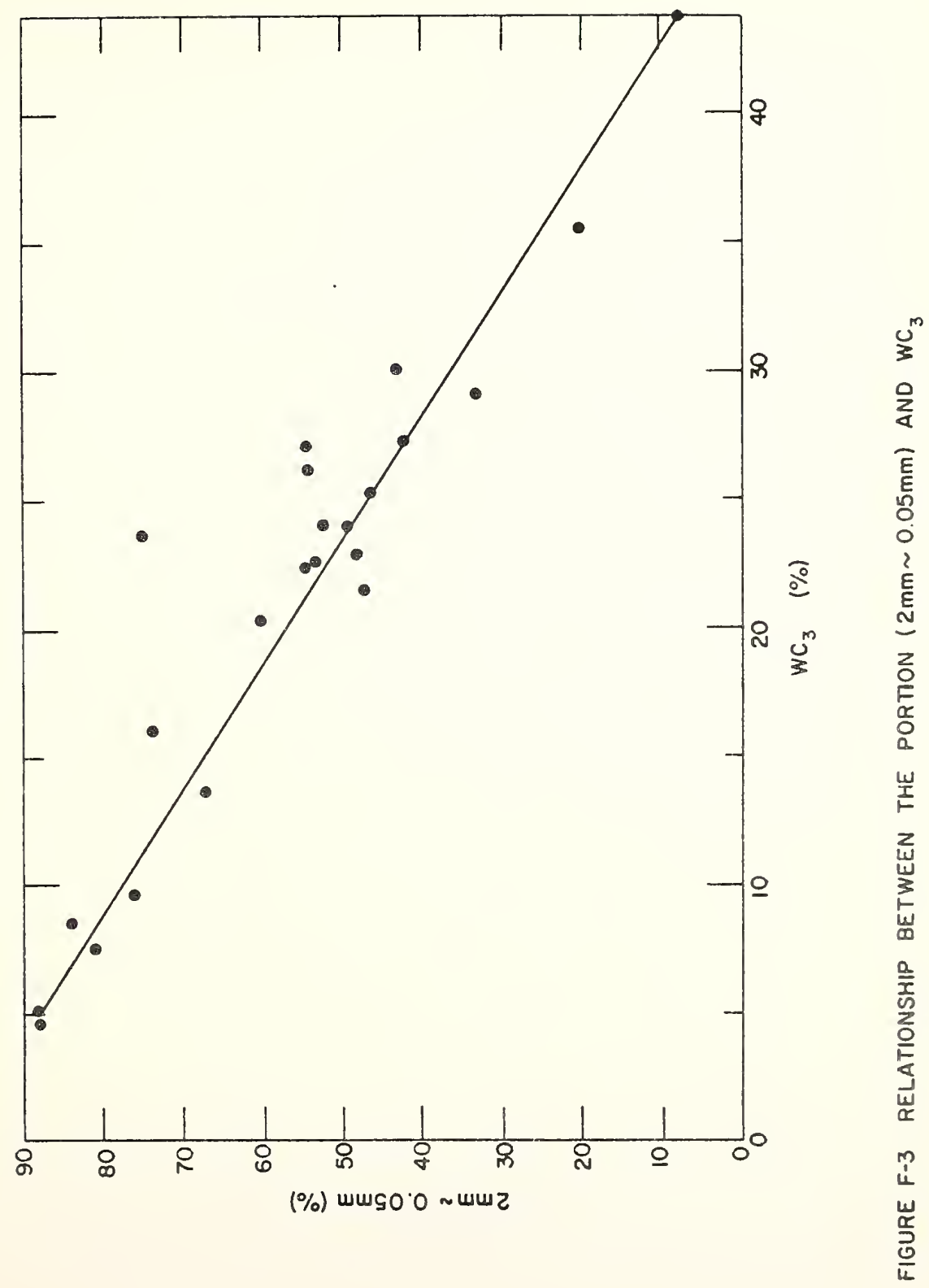




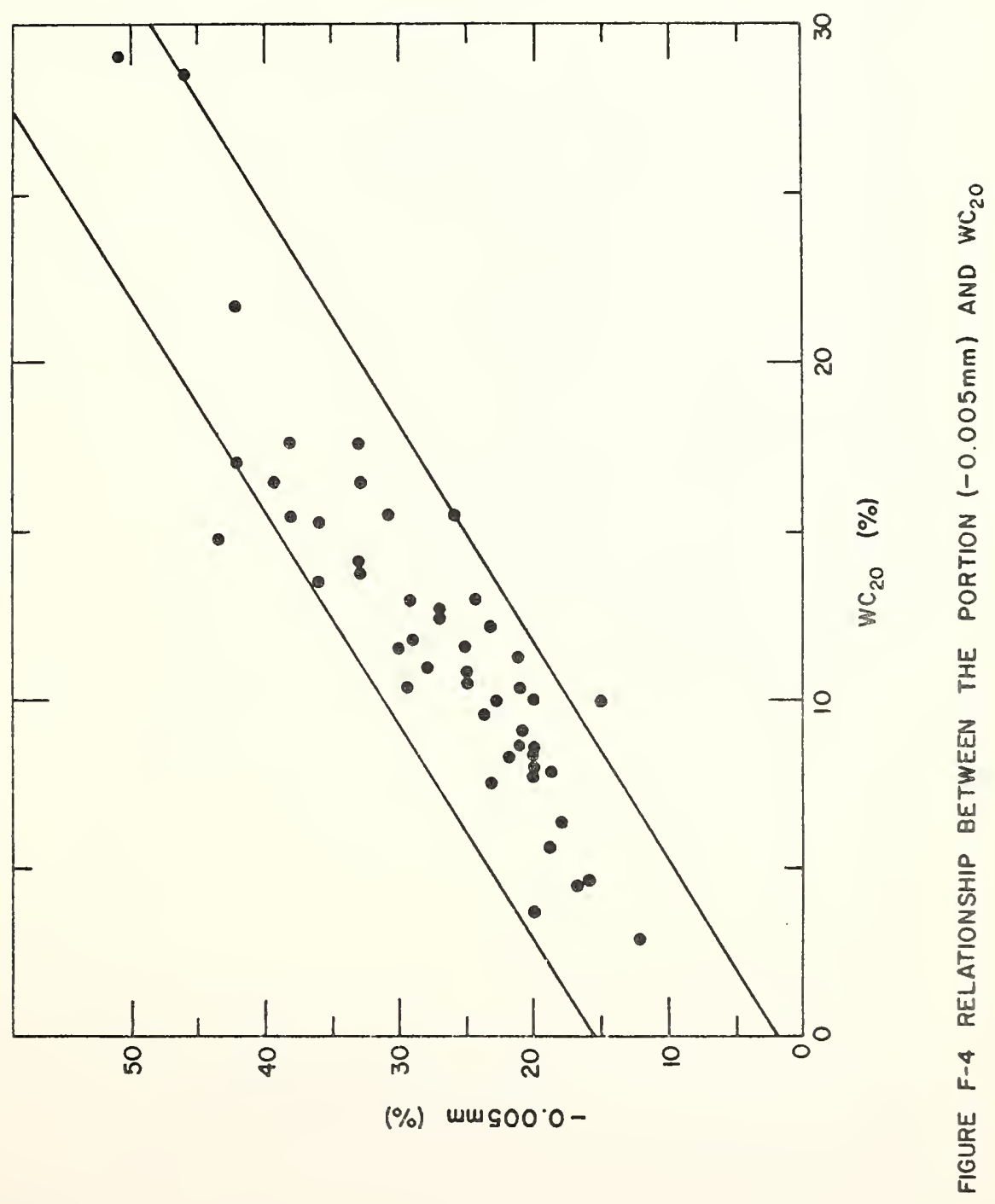




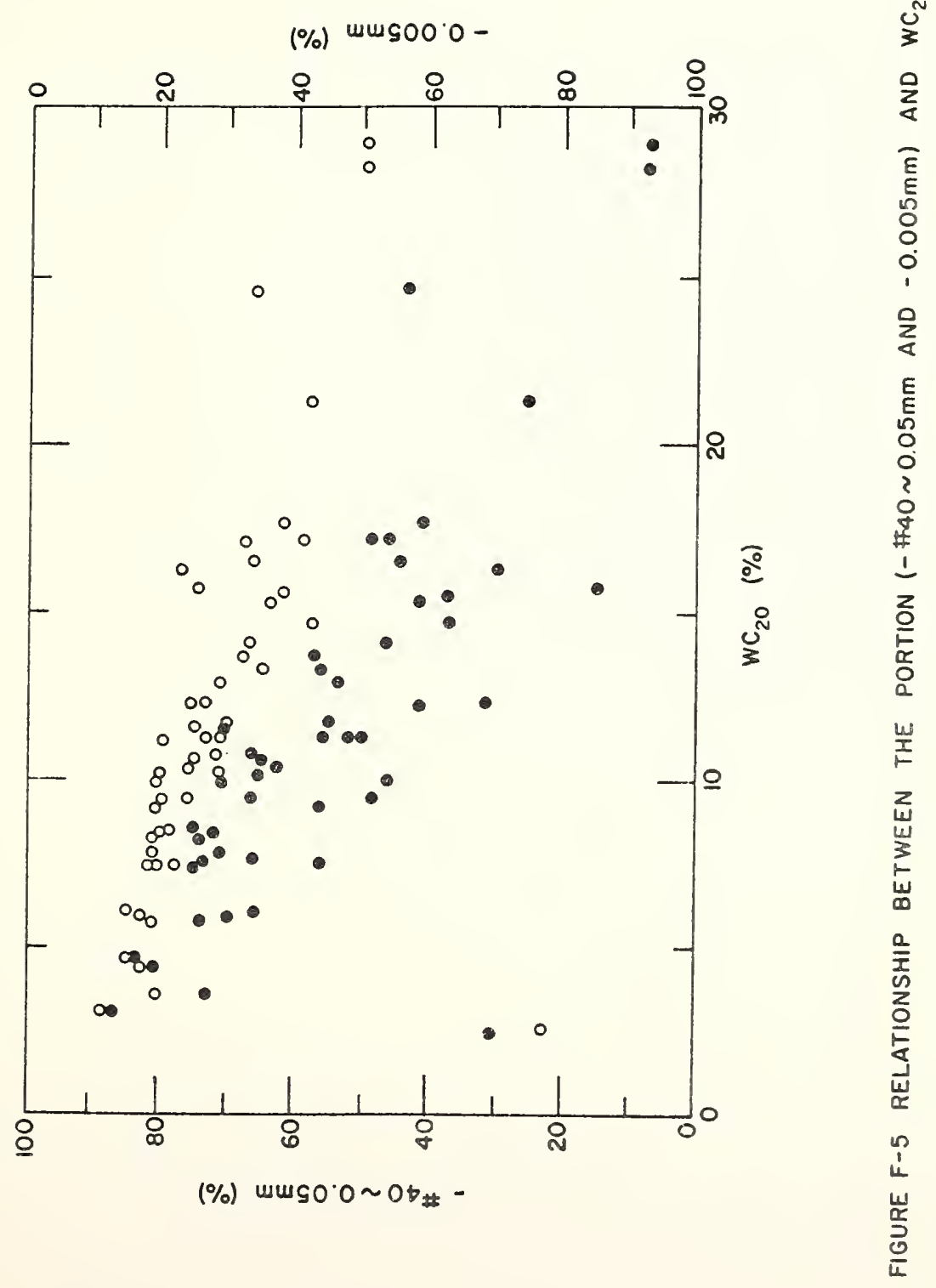




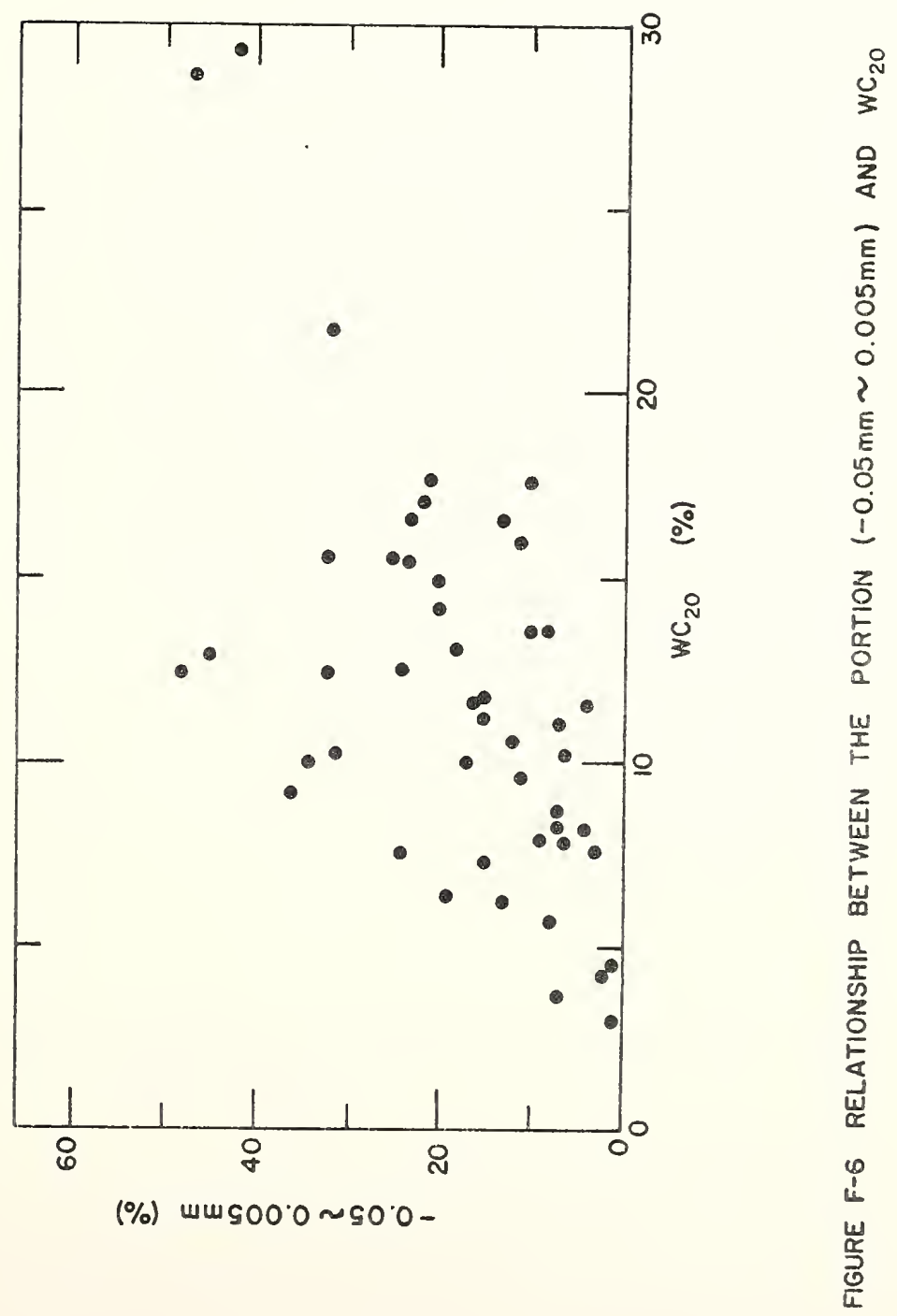




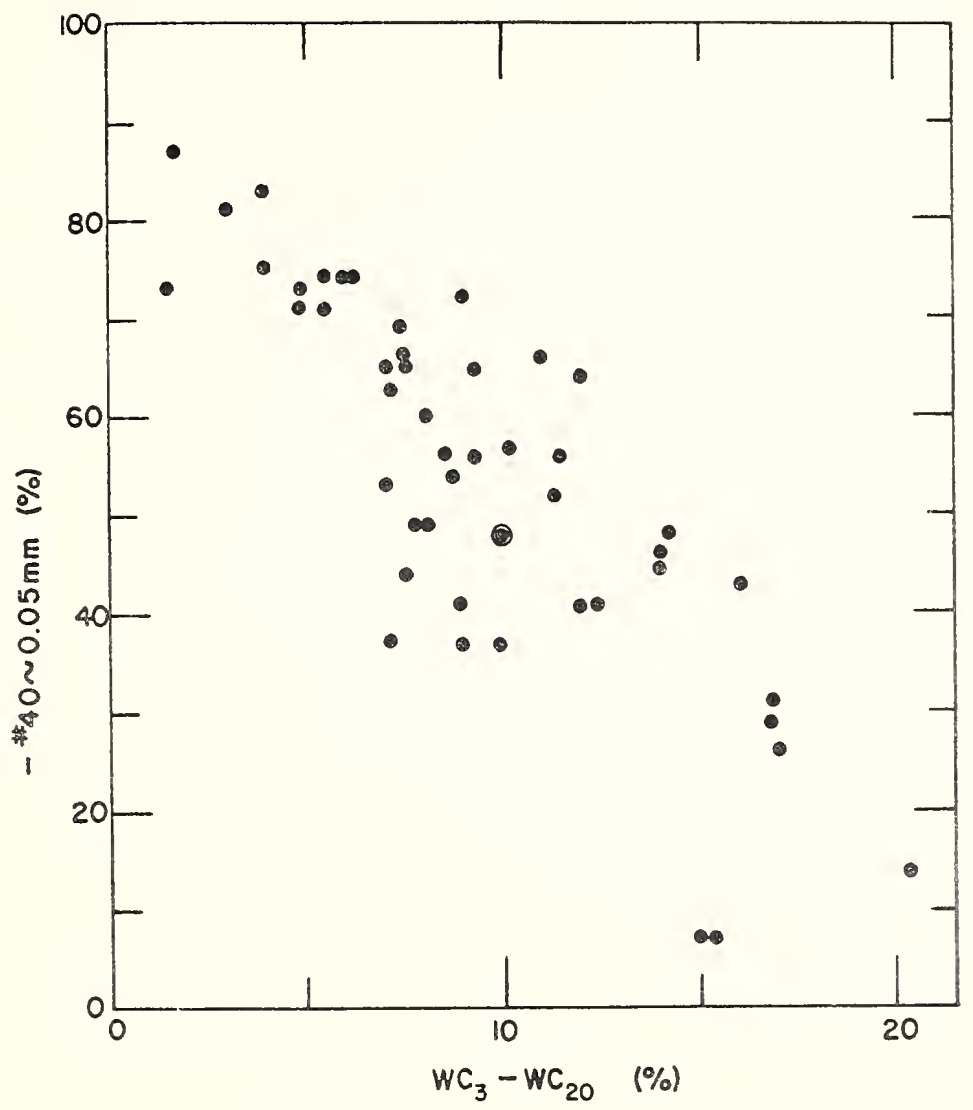

FIGURE F-7 RELATIONSHIP BETWEEN THE PORTION (- $\$ 40 \sim 0.05 \mathrm{~mm}$ ) AND $\left(W C_{3}-W C_{2 O}\right)$ 


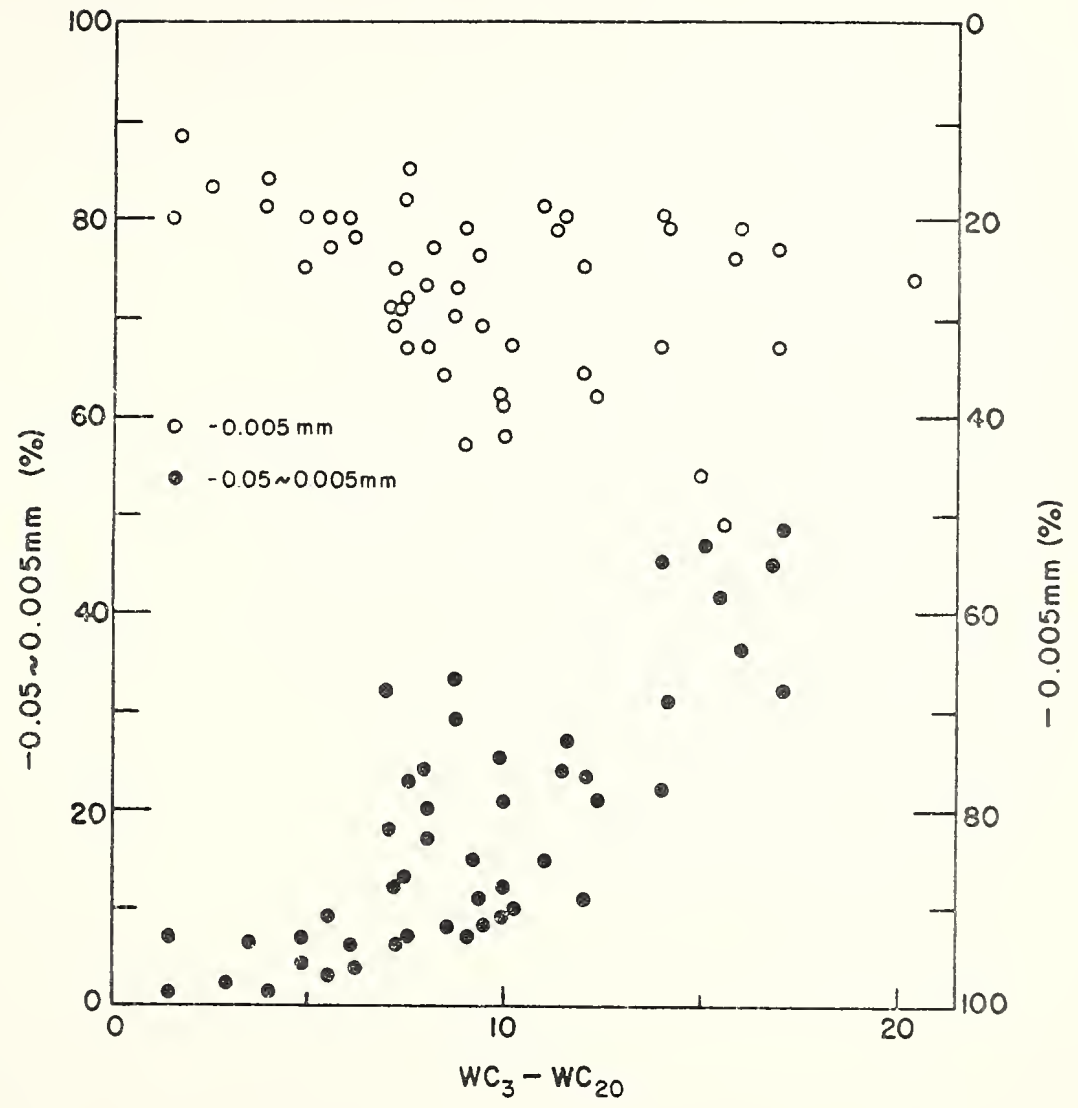

FIGURE F-8 RELATIONSHIP BETWEEN THE PORTION $(-0.05 \sim 0.005 \mathrm{~mm}$ AND $-0.005 \mathrm{~mm})$ AND $\left(W C_{3}-W C_{20}\right)$ 

